
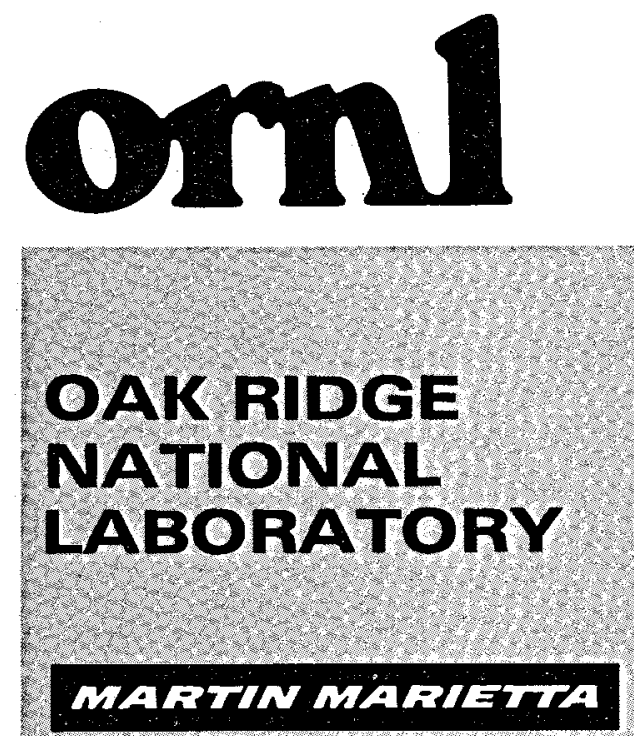

\section{MANAGED BY}

MARTIN MARIETTA ENERGY SYSTEMS, INC.

FOR THE UNITED STATES

DEPABTMENT OF ENERGY
RECEIVED

ORNL/TM-12859

\title{
ENVIRONMENTAL RESOURCES OF SELECTED AREAS OF HAWAII: CULTURAL ENVIRONMENT AND AESTHETIC RESOURCES
}

\author{
by \\ Lillian D. Trettin, \\ Carl H. Petrich, and \\ J. W. Saulsbury \\ Robert M. Reed, \\ Project Manager
}




\section{DISCLAIMER}

This report was prepared as an account of work sponsored by an agency of the United States Government. Neither the United States Government nor any agency Thereof, nor any of their employees, makes any warranty, express or implied, or assumes any legal liability or responsibility for the accuracy, completeness, or usefulness of any information, apparatus, product, or process disclosed, or represents that its use would not infringe privately owned rights. Reference herein to any specific commercial product, process, or service by trade name, trademark, manufacturer, or otherwise does not necessarily constitute or imply its endorsement, recommendation, or favoring by the United States Government or any agency thereof. The views and opinions of authors expressed herein do not necessarily state or reflect those of the United States Government or any agency thereof. 


\section{DISCLAIMER}

Portions of this document may be illegible in electronic image products. Images are produced from the best available original document. 
This report has been reproduced directly from the best available copy.

Available to DOE and DOE contractors from the Office of Scientific and Technical information, P.O. Box 62, Oak Ridge, TN 37831; prices available from (615) 576-8401, FTS 626-8401.

Available to the public from the Nationa! Technical Information Service, U.S. Department of Commerce, 5285 Port Royal Rd., Springfield, VA 22161.

This report was prepared as an account of work sponsored by an agency of the United States Government. Neither the United States Government nor any agency thereof, nor any of their employees, makes any warranty, express or implied, or assumes any legal liability or responsibility for the accuracy, completeness, or usefulness of any information, apparatus, product, or process disclosed, or represents that its use would not infringe privately owned rights. Reference herein to any specific commercial product, process, or service by trade name, trademark, manufacturer, or otherwise, does not necossarily constitute or imply its endorsement, recommendation, or favoring by the United States Government or any agency thereof. The viows and opinions of authors expressed herein do not necessarily state or reflect those of the United States Government or any egency thereof. 
ORNL/TM-12859

\title{
ENVIRONMENTAL RESOURCES OF SELECTED AREAS OF HAWAII:
} CULTURAL ENVIRONMENT AND AESTHETIC RESOURCES

\author{
Lillian D. Trettin 1 \\ Carl H. Petrich \\ J. W. Saulsbury \\ Robert M. Reed, Project Manager \\ Energy Division
}

January 1996

$\overline{{ }^{1} \text { University of Tennessee }}$

\author{
Prepared for \\ U.S. Department of Energy \\ Oak Ridge Operations Office \\ by the \\ OAK RIDGE NATIONAL LABORATORY \\ Oak Ridge, Tennessee 37831 \\ managed by \\ LOCKHEED MARIETTA ENERGY RESEARCH CORP. \\ for the \\ U.S. DEPARTMENT OF ENERGY \\ under contract DE-AC05-96OR22464
}


[Blank Page]

de 
LIST OF FIGURES $\ldots \ldots \ldots \ldots \ldots \ldots \ldots \ldots \ldots \ldots \ldots \ldots \ldots \ldots \ldots \ldots \ldots \ldots$

LIST OF TABLES $\ldots \ldots \ldots \ldots \ldots \ldots \ldots \ldots \ldots \ldots \ldots \ldots \ldots \ldots \ldots \ldots \ldots \ldots$

ACRONYMS $\ldots \ldots \ldots \ldots \ldots \ldots \ldots \ldots \ldots \ldots \ldots \ldots \ldots \ldots \ldots \ldots \ldots \ldots$

1. INTRODUCTION $\ldots \ldots \ldots \ldots \ldots \ldots \ldots \ldots \ldots \ldots \ldots \ldots \ldots \ldots \ldots \ldots \ldots$,

2. NATTVE HAWAIIAN CULTURAL AND RELIGIOUS RIGHTS, PRACTICES, AND

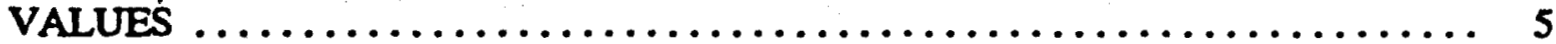

2.1 TRADITIONAL RIGHTS TO AND USES OF LAND AND NATURAL

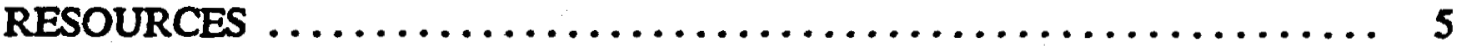

2.1.1 Trust Lands and Land Grants .................... 7

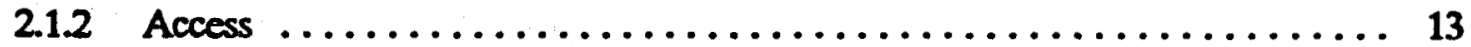

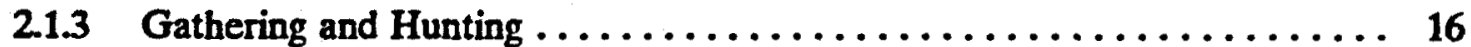

2.1.4 Shoreland and Near-Shore Marine Resources, and Submerged

Lands ................................... 18

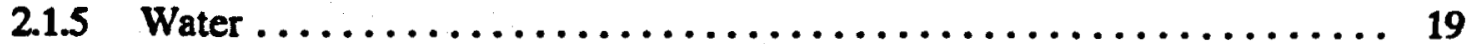

2.2 NATIVE HAWAIIAN RELIGION AND BURIAL PRACTICES: RIGHTS

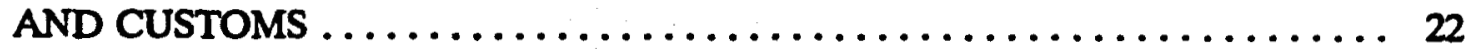

2.2.1 Native Hawaiian Religion and Spirituality ................ 22

2.2.2 Pele in Mythology and Contemporary Belief ............... 24

2.2.3 Native Hawaiian Burial Rights and Practices ............... 25

2.3 PERSISTENCE OF CORE CULTURAL VALUES ............... 26

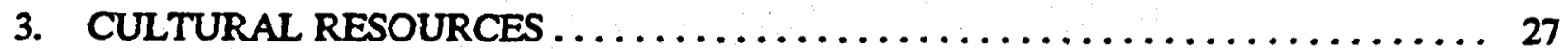

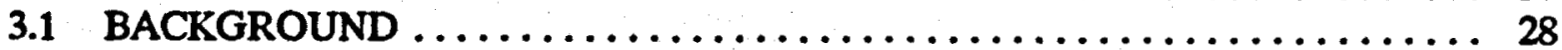

3.2 PREHISTORIC AND HISTORIC SITES ... . . . . . . . . . . . . . . 29

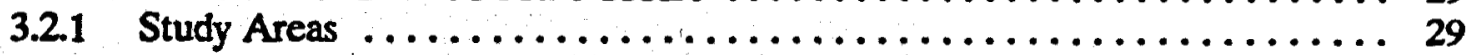

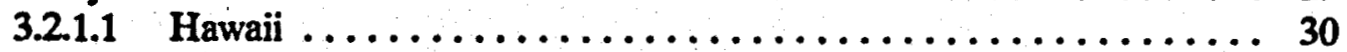

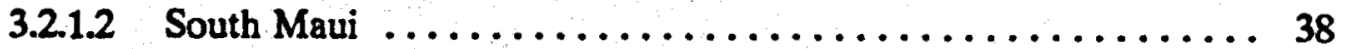

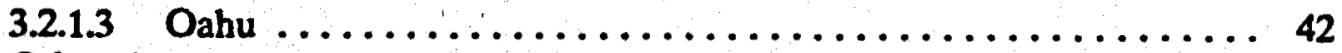

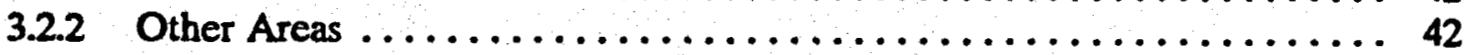

3.3 OTHER HISTORIC RESOURCES $\ldots \ldots \ldots \ldots \ldots \ldots \ldots \ldots \ldots \ldots \ldots \ldots \ldots \ldots$

4. AESTHETIC RESOURCES $\ldots \ldots \ldots \ldots \ldots \ldots \ldots \ldots \ldots \ldots \ldots \ldots \ldots \ldots \ldots \ldots \ldots$

4.1 SOUTHEASTERN HAWAII $\ldots \ldots \ldots \ldots \ldots \ldots \ldots \ldots \ldots \ldots \ldots \ldots \ldots \ldots$

4.2 POTENTIAL DEVELOPMENT CORRIDOR BETWEEN HILO AND THE

NORTH KOHALA DISTRICT $\ldots \ldots \ldots \ldots \ldots \ldots \ldots \ldots \ldots \ldots \ldots \ldots \ldots$

4.2 .1 Saddle Road Area $\ldots \ldots \ldots \ldots \ldots \ldots \ldots \ldots \ldots \ldots \ldots \ldots \ldots \ldots \ldots$

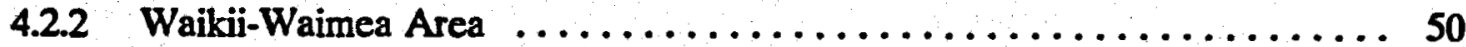

4.2 .3 North Kohala Area $\ldots \ldots \ldots \ldots \ldots \ldots \ldots \ldots \ldots \ldots \ldots \ldots \ldots \ldots \ldots$

4.3 SOUTHEASTERN MAUI $\ldots \ldots \ldots \ldots \ldots \ldots \ldots \ldots \ldots \ldots \ldots \ldots \ldots \ldots \ldots \ldots$ 


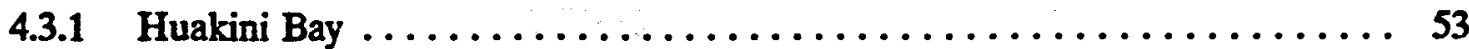

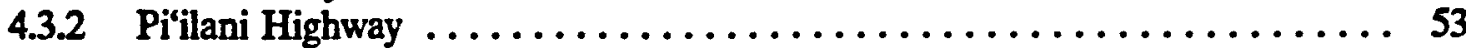

4.3 .3 Ahihi Bay and Kanahena $\ldots \ldots \ldots \ldots \ldots \ldots \ldots \ldots \ldots \ldots \ldots \ldots$

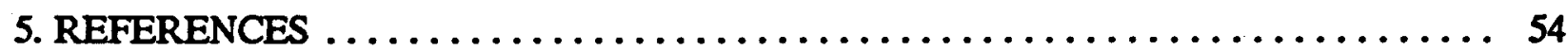

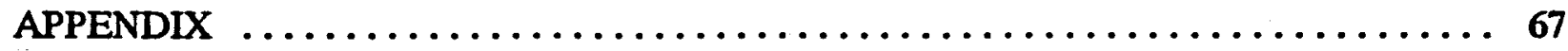




\section{LIST OF FIGURES}

Figure

Page

1 Hawaii County: census districts and principal towns $\ldots \ldots \ldots \ldots \ldots \ldots \ldots$

$2 \quad$ Hawaii County: major road segments $\ldots \ldots \ldots \ldots \ldots \ldots \ldots \ldots \ldots \ldots \ldots$

3 Maui County: areas of interest along the southern coast and

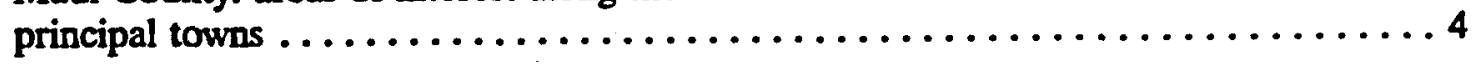

4 Selected Hawaiian homelands, hunting areas, and major trails associated with study areas on the island of Hawaii $\ldots \ldots \ldots \ldots \ldots \ldots \ldots \ldots \ldots \ldots$

5 Selected prehistoric and historic sites, other culturally sensitive areas, and major trails on northwest Hawaii $\ldots \ldots \ldots \ldots \ldots \ldots \ldots \ldots \ldots \ldots \ldots$

6 Selected Hawaiian homelands, major trails, and other culturally

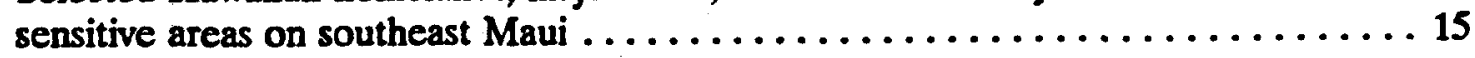

7 Areas of potential archeological sensitivity on Oahu 43

\section{LIST OF TABLES}

Table

Hawaiian homelands in the overall study area $\ldots \ldots \ldots \ldots \ldots \ldots \ldots \ldots$

$2 \quad$ Rural, wild, and sensitive trails $\ldots \ldots \ldots \ldots \ldots \ldots \ldots \ldots \ldots \ldots \ldots \ldots$

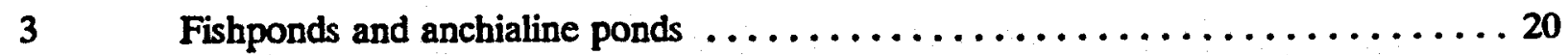

$4 \quad$ National Register and National Landmark sites and districts . . . . . . . . 36 


\section{ACRONYMS}

AIRFA American Indian Religious Freedom Act

AHPA Archaeological and Historic Preservation Act

ARPA Archaeological Resources Protection Act

CANDO Cultural Advocacy Network Developing Options

DBED Department of Business and Economic Development

DHHL Department of Hawaiian Home Lands

DLNR Department of Land and Natural Resources

DOE U.S. Department of Energy

EIS environmental impact statement

EMF electric and magnetic fields

GRSs Geothermal Resource Subzones

GRZ Geothermal Resource Zone

HGP Hawaii Geothermal Project

HRHP Hawaii Register of Historic Places

IARII International Archaeological Research Institute, Inc.

NAGPRA Native American Graves Protection and Repatriation Act

NAR Natural Area Reserve

NHPA National Historic Preservation Act

NPS National Park Service

NRHP National Register of Historic Places

NEPA National Environmental Policy Act

RFRA Religious Freedom Restoration Act 

4 


\section{INTRODUCTION}

This report has been prepared to make available and archive the background scientific data and related information collected on the cultural environment and aesthetic resources during the preparation of the environmental impact statement (EIS) for Phases 3 and 4 of the Hawaii Geothermal Project (HGP) as defined by the state of Hawaii in its April 1989 proposal to Congress. The U.S. Department of Energy (DOE) published a notice in the Federal Register on May 17, 1994 (Fed. Regis. 59, 25638) withdrawing its Notice of Intent (Fed. Regis. 57, 5433) of February 14, 1992, to prepare the HGP-EIS. Because the state of Hawaii is no longer pursuing or planning to pursue the HGP, DOE considers the project to be terminated.

The background scientific data and related information presented in this report focuses on several areas of Hawaii County, including the southeastern coast, a potential development corridor along the Saddle Road between Hilo and the North Kohala District on the northwestern coast (Figs. 1 and 2), and on the southeastern coast of Maui County (Fig. 3). In this report, these areas are referred to as study areas rather than areas where proposed or alternative facilities of the HGP were to have been located. The scientific background data and related information are being made available for use by others in conducting future scientific research in these areas. This report describes the cultural environment and aesthetic resources present in the areas studied (i.e., the affected environment) and does not represent an assessment of environmental impacts.

The cultural environment in the Geothermal Resource Zone (GRZ) and associated study area consists of Native Hawaiian cultural and religious practices and both Native Hawaiian and non-Native Hawaiian cultural resources. "Native Hawaiian" refers to persons of full- and partHawaiian heritage except when explicit reference is made to a percentage of native ancestry (Native Hawaiian Study Commission 1983). The following discussion of cultural resources consists of three sections: (1) a description of Native Hawaiian cultural and religious rights, practices, and values; (2) a description of historic, prehistoric, and traditional Native Hawaiian sites; and (3) a description of other (non-native) sites that could be affected by development in the study area. Within each section, the level of descriptive detail varies according to the information currently available.

The description of the cultural environment is most specific in its coverage of the Geothermal Resource Subzones (GRSs) in the Puna District of the island of Hawaii and the study area on South Maui. Ethnographic and archaeological reports by Cultural Advocacy Network Developing Options (CANDO) and International Archaeological Research Institute, Inc. (IARII), respectively, supplement the descriptions of these two areas with new information collected specifically for this study. Less detailed descriptions of additional study areas on Oahu, Maui, Molokai, and the island of Hawaii are based on existing archaeological surveys. The type of cultural description also varies according to the planning approach deemed most appropriate for a particular study area (Downer and Roberts 1993). Two approaches have been used, a comprehensive approach for identifying the full range of resources in two broadly defined 


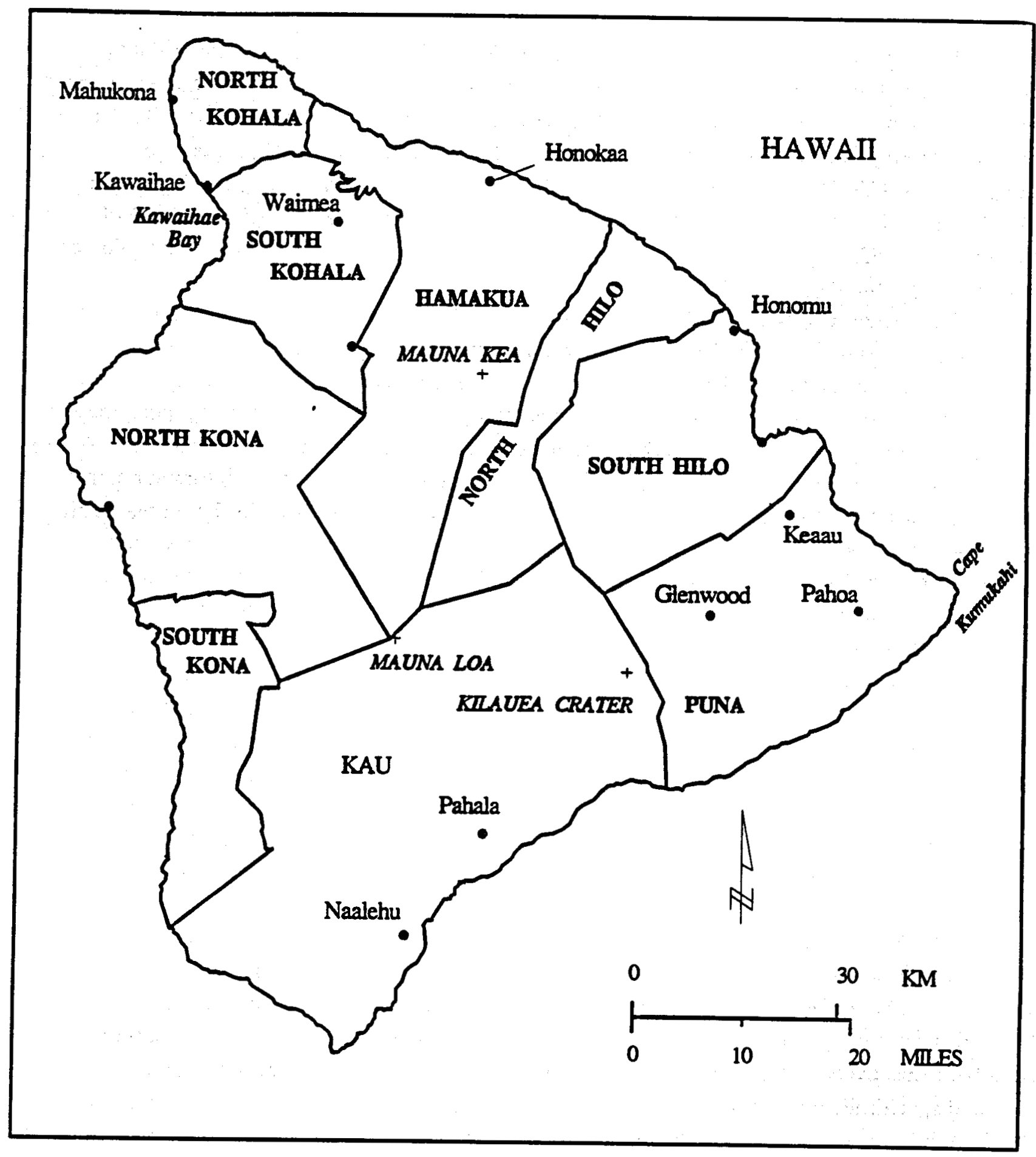

Fig. 1. Hawaii County: Census districts and principal towns. 


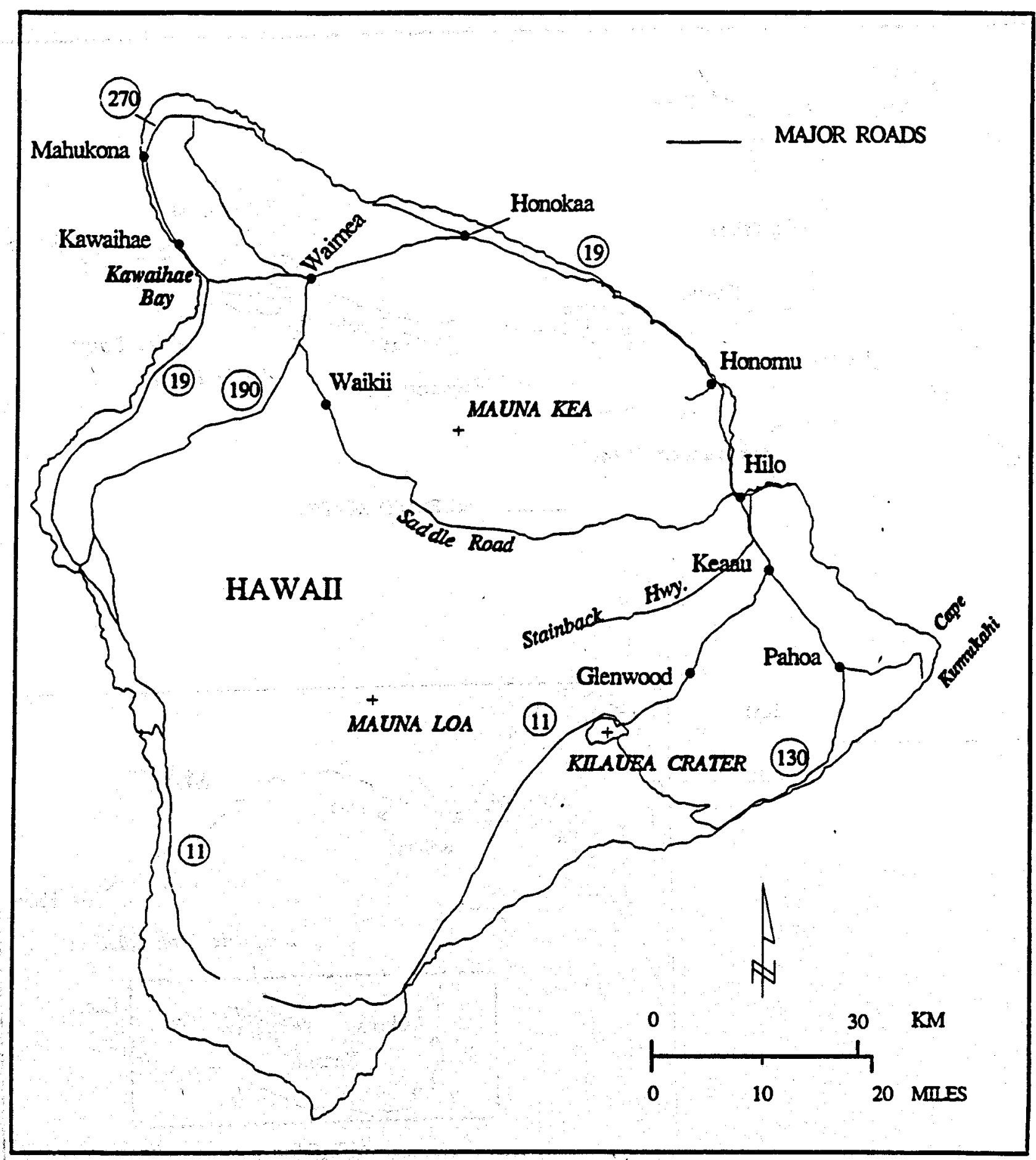

Fig. 2 Hawaii County. Major road segments. 


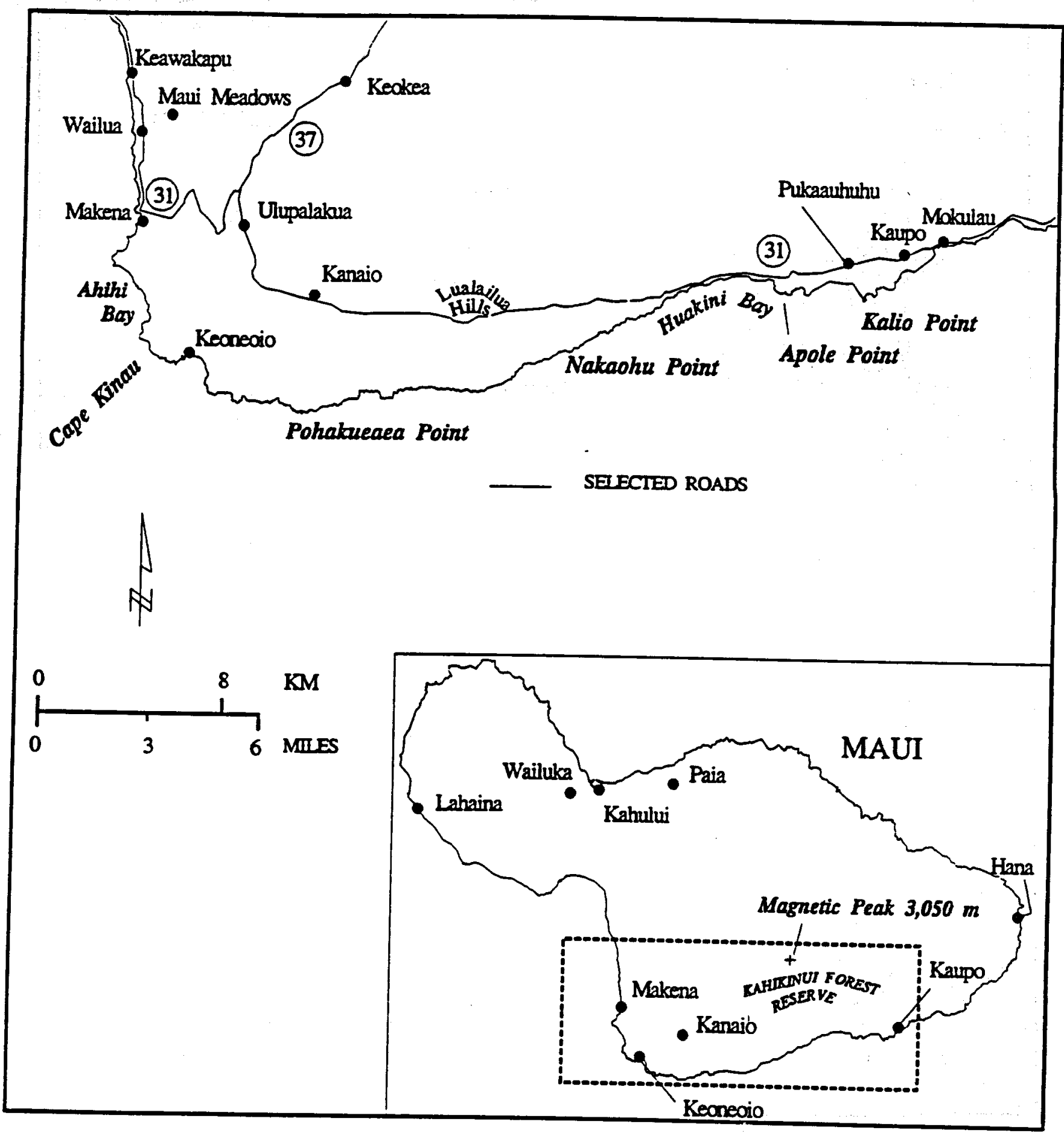

Fig. 3. Maui County. Areas of interest along the southern coast and principal towns. 
areas-the Puna GRSs and South Maui-and a selective approach for identifying other key resources in additional study areas.

\section{NATIVE HAWAIIAN CULTURAL AND RELIGIOUS RIGHTS, PRACTICES, AND VALUES}

This section describes traditional Native Hawaiian rights to and uses of land and natural resources, traditional Native Hawaiian religion and burial practices, and core Native Hawaiian cultural values pertinent to the study area (see also Matsuoka et al. 1995). An appendix to this report describes major state and federal legislation that protects or is relevant to Native Hawaiian culture and cultural resources in general. Most recently, the passage in 1994 of Executive Order 12898, "Federal Actions to Address Environmental Justice in Minority Populations and Lowincome Populations" expands the federal mandate to ensure public participation and access to the federal decision-making process, improve research and data collection efforts, and identify differential patterns of traditional subsistence use.

\section{TRADITIONAL RIGHTS TO AND USES OF LAND AND NATURAL RESOURCES}

Because development could occur in areas of particular importance to Native Hawaiians, two teams of professional researchers, located in Hawaii, conducted ethnographic and archaeological studies to provide detailed cultural information on two regions: the Puna District of the island of Hawaii and the southern region of Maui. These teams included specialists in archaeology, anthropology, sociology, history, and regional planning, as well as Native Hawaiian cultural authorities. Their interdisciplinary approach to designing and carrying out the studies provided the most reliable means of avoiding inadvertent bias and ensuring the successful resolution of any potential conflicts over interpretation. Specialists in these fields recognize the importance of clarifying definitions of "traditional culture." During attempts to authenticate traditional practices or cultural sites, individuals or groups sometimes disagree on the degree to which certain practices or sites can be labeled "traditional." Disagreements are particularly likely to occur when individuals or groups associate various political and economic interests with a proposed land change that could affect such practices or sites. Individuals or groups may differ in their reliance on available documentary sources or archaeological evidence to authenticate traditional culture or in their belief in the relative importance of revitalizing or promoting traditional culture (Parker and King 1990).

In Hawaii, specialists draw distinctions among traditions thought to have occurred prior to the arrival of Europeans, traditions that emerged during the early period of contact with western civilization (prior to c. 1850), and traditions known to have beerr held or practiced with a degree of continuity and integrity for over 50 years (McEldowney 1994). Except for sections relying heavily on archaeological investigation, this report addresses topics and issues from the 
perspective of traditions known to have been practiced or held for over $\mathbf{5 0}$ years in the Puna District of the island of Hawaii and the southern region of Maui. A brief description of the Puna District and South Maui follows.

The Puna District is a geographically, culturally, and socially distinct rural area. It includes a significant group of families descended from the original Hawaiian settlers who live in and near the communities of Kalapana, Kaimu, Opihikao, and Pohoiki. New subdivisions opened in the district in 1958, and since then, a growing number of young Hawaiian families have also migrated to Puna from Hilo, Honolulu, and other places on neighboring islands (Matsuoka et al. 1995). "Native Hawaiian residents in the district supplement their incomes from jobs or public assistance by engaging in subsistence fishing, hunting, and gathering for the households of their 'ohana, or extended family. The fishermen, hunters, and gatherers utilize and exercise their traditional access to the ocean offshore of the Puna district and the adjacent mauka (upland) forest lands. This forest area afforded access to middle elevation plants and resources for Hawaiians who lived in each of the ahupua'a [traditional divisions] of the Puna district" (Matsuoka et al. 1995).

South Maui is "an unspoiled scenic district of forests, pastoral grasslands, lava outcrops, and Hawaiian plants surviving in the ravines and gulches". (Matsuoka et al. 1995). The area from Huakini Bay to Ahihi Bay includes sections of the Kahikinui Cultural Management Zone of the Department of Hawaiian Home Lands (DHHL) and the State Natural Area Reserve (NAR) of Cape Kina'u, as well as lands awarded or leased to Native Hawaiians at Kanaio and Kabikinui and considerable acreage leased to ranches (see Sect. 21.1 below). While largely uninhabited (unlike the Puna District), the coastline and upland slopes of South Maui are important sites of recreation and subsistence activity for residents of the Makawao and Hana districts, who live primarily in Hana, Kihei, and the small communities in between. South Maui is "a remote place where Hawaiians can reconnect with another time and their cultural roots; where they engage in subsistence activities, like hunting and fishing, following the moon, the sun, the stars, the tides, the weather and the seasons; where they feel in contact with nature, physically and spiritually" (Matsuoka et al. 1995). For both Puna and South Maui, as for other relatively undeveloped places in the Hawaiian islands, subsistence living and a sense of spiritual connectedness to the landscape represent fundamentals of traditional Hawaiian values and culture to many Hawaiians.

While a broad spectrum of Native Hawaiians agree on the significance of these traditions, they sometimes differ in their understanding of what "tradition" means today. As residential, resort, and industrial development encroach on rural areas, Hawaiians bent on maintaining traditional ways of life find they must adapt to new constraints. For example, Hawaiians who formerly gathered the most potent herbs near the coast of Puna now gather them instead in the undeveloped upland areas because that is where they can still find them (Matsuoka et al. 1995). Those who adapt old skills to new situations call their behavior "traditional." Others question whether this behavior is authentic (see Sect. 2.2.1).

Hawaiians may vary in their understanding of traditional behavior, tut they agree on the importance of maintaining state-protected customary rights. State statutes (including Hawaii Revised Statutes, Sect. 7-1 and Sect. 1-1, and the Hawaiian Homes Commission Act) and the 
Hawaii State Constitution (Article XII, Sect. 7) protect various rights of Native Hawaiians to use or profit from natural resources in the study areas. These rights include the right to bomestead on or receive revenue from trust lands; the right of ahupua'a residents and kuleana tenants to secure access to homesteads, gathering areas, sacred places, and beaches; the right to hunt and gather for customary, religious, and subsistence purposes; and the right to use shoreline, near-shore marine, and fresh water resources.

\subsection{Trust Lands and Land Grants}

Hawaiians have considerable legal interests in land. Hawaiian trust lands consist of ceded lands and a subcategory of ceded lands known as Hawaiian Home Lands. Ceded lands were part of the Hawaiian monarchy's Government and Crown lands until 1898, when the monarchy ceded them to the U.S. government, which in turn ceded them to the state of Hawaii in 1959. Today, ceded lands account for $90 \%$ of the 1.4 million acres owned by the state. In 1921, 203,000 acres of ceded lands were set aside and designated as "homelands" under the Hawaiian Homes Commission Act for leasing to Native Hawaiians of $50 \%$ native ancestry for activities like pastoral homesteading and for support services. The current inventory of home lands includes 188,000 acres, and a waiting list for their use included over 18,000 names in 1991 (Rowe 1991). All ceded lands are subject to a trust requirement. Twenty percent of lease rents, royalty payments, and other revenue derived from ceded lands accrue to Native Hawaiians of $50 \%$ native ancestry, and the other $80 \%$ becomes available to the state for expenditure on the population at large. The state has not yet determined whether any of these revenues could be used to directly benefit Hawaiians of less than 50\% native ancestry (MacKenzie 1991; Parker 1989). Under the state's Hawaiian Homes Commission Act, Sections 204-207, the administration of home lands is predicated on the demonstration of benefits to Native Hawaiians. The needs of individual Native Hawaiian beneficiaries outweigh those of the "public good" (Rowe 1991).

Portions of the GRSs could be subject to this requirement. Act 241 of 1974 redefined geothermal reserves as a mineral resource rather than a water resource. If the case were to be made that the state retains claims to subsurface mineral reserves regardless of surface land transactions, or that it acquires claims to newly discovered ones, then the revenues generated by mineral lease rents in the GRSs would be subject to the trust requirement (Kamins 1980). However, a court determination would be required to ascertain where the state maintains reserved mineral rights (Kamins 1980).

Many of the study areas include ceded lands, for example, the Waiakea Lava Flow NAR on the island of Hawaii and the Ahihi-Kinau NAR on Maui. They also include Hawaiian Home Lands, some of which have been developed or are scheduled for development by Native Hawaiians (see Table 1 and Figs. 4 and 5). Hawaiian Home Lands at Kawaihae on the island of Hawaii and Kahikinui on Maui are particularly sensitive. The situation in Kahikinui is aggravated by the fact that large amounts of acreage were previously leased to non-Hawaiian entrepreneurs for ranching rather than to benefit Native Hawaiians. As those leases expire, Hawaiians propose 
Table 1. Hawaiian homelands in the overall study area

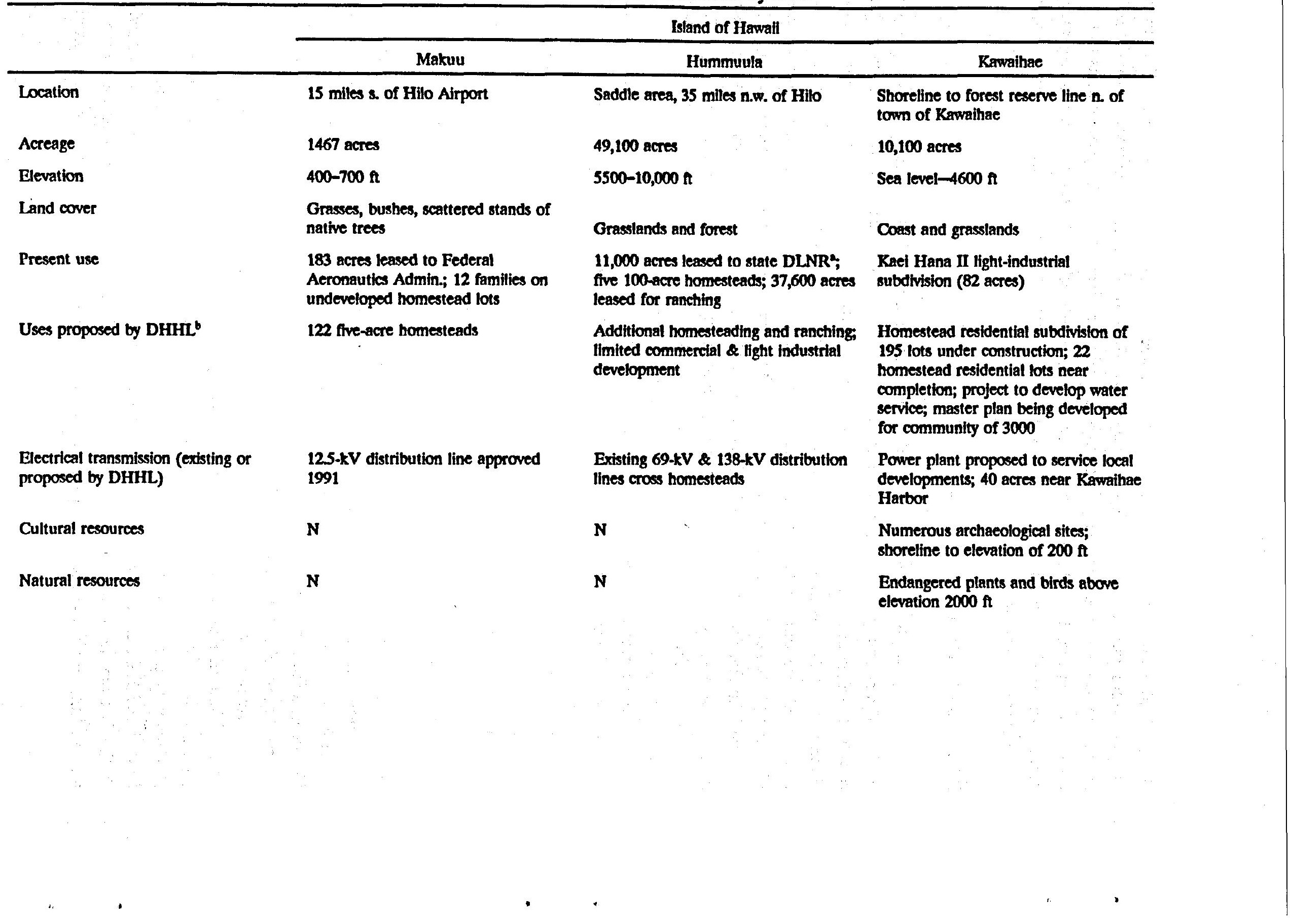


Table 1 (continued)

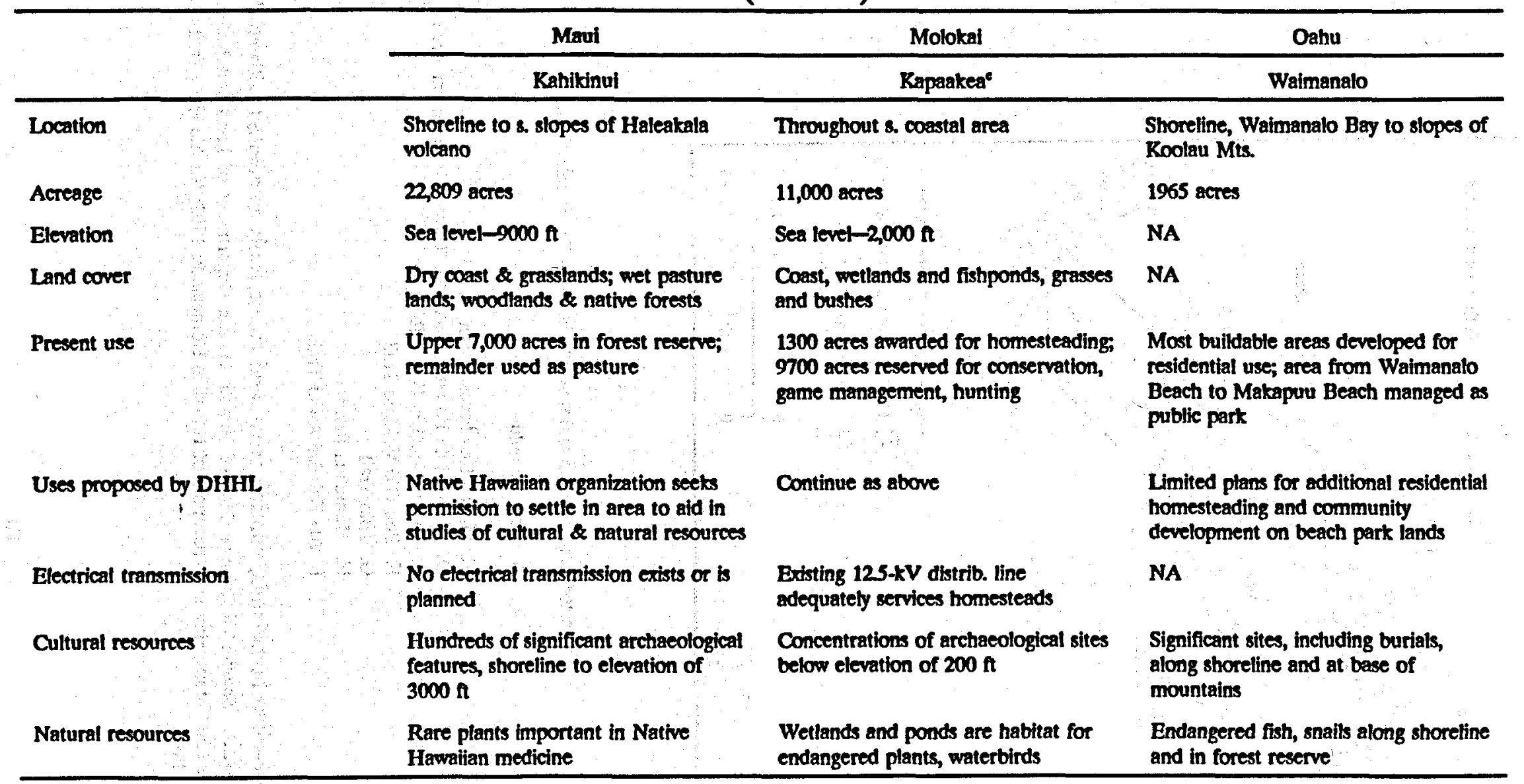

Nore: $\mathrm{N}=$ Resources not identified; $\mathrm{NA}=$ Information not available.

DLNR = State Department of Land and Natural Resources.

DDHHL = State Department of Hawaiian Home Lands.

'Additionali home lands along the south shore include Kamiloloa and Makakupaia/Kalamaula/Palaau Apana.

Sounce: DHHL 1993. 


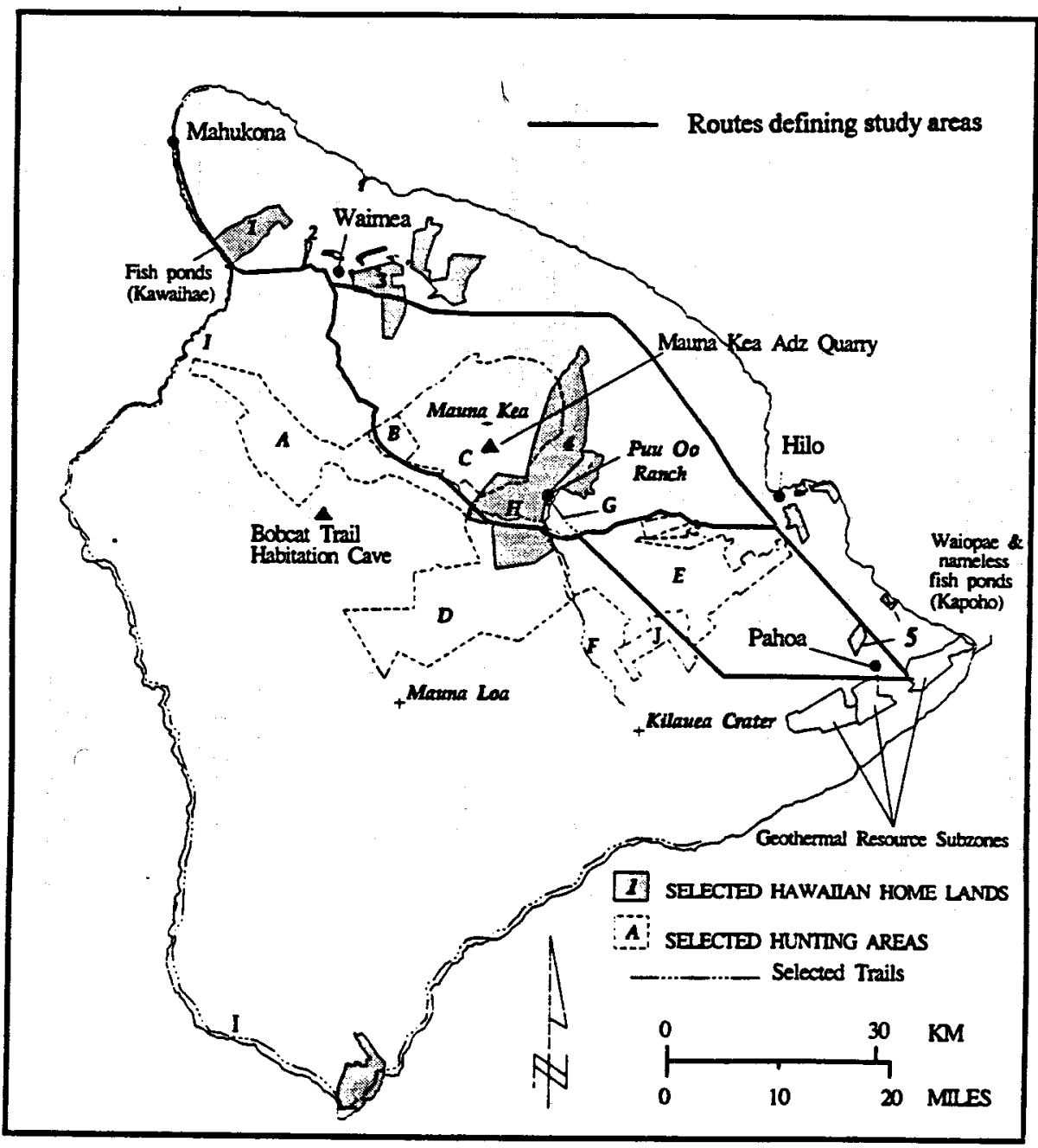

Key:

Selected Hawaiian Homeland

1. Kawaihae

2. Pauahi

3. Puukapu

4. Humuula

5. Makuu
Selected bunting areas and major trails along the Saddle Route
A. Puu Anahulu
B. Kaobe
C. Mauna Kea Forest Reserve
D. Mauna Loa Forest Reserve and Game Management Area
E. Upper Waiakea Forest Reserve
F. Puu O'o Volcano Trail
G. Hilo Trail
H. Humu'ula Road
I. Ala Kahakai-Awini Trail

Fig. 4. Selected Hawaiian homelands, hunting areas, and major trails associated with study areas on the island of Hawaii. Source: Recreation Map of Hawaii, Hawaii Department of Land and Natural Resources, 1986; Hawaiian Home Land Maps, Hawaii Department of Hawaiian Homelands, 1992; Na Ala Hele Trail and Access Program, Hawaii DLNR, 1991. 


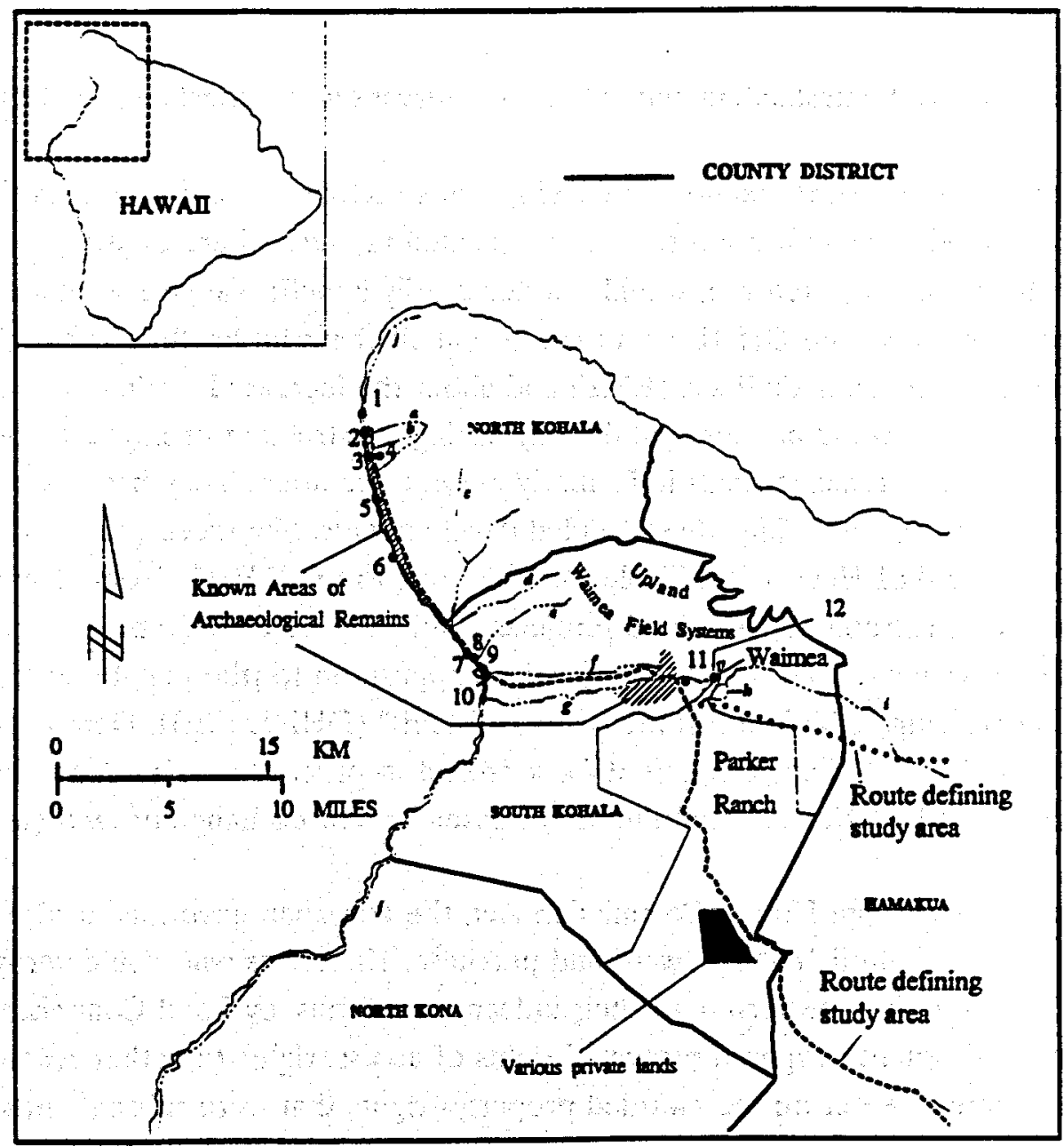

Key.

Major prehistoric and historic sites or culturally sensitive areas

1. Railroad shed and rail bed, Mahukona Harbor

2. Mahukona heaiu and shrines

3. Lapakahi State Historic Park

4. Lapakahi mauka

5. Lamaloloa complex

6. Coastal habitation sites

7. Burial sites

8. Temporary shelters and Kawaihae royal center

9. Pelekane

10. Puukohola Heiau National Historic site
Majox trails listed in the Na Ala Hele Trails and Acoess System

a. Lapakahi-Paoo Trail

b. Koaeae Mauka-Makai Trail

c. Kawaihae-Puu Kue Trail

d. Kawaihae-Hoepa Trail

c. Kawaihae-Kawaihae Uka Trail

f. Old Kawaihae-Waimea Road

g. Waikoloa Stream Trail

h. Waimea Loop Trail

i. Imiola-Mana Trail

j. Ala Kahakai-Awini Trail

Fig. 5. Selected prehistoric and historic sites, other culturally sensitive areas, and major trails on northwest Hawaii. Source: Northwest Hawaii Open Space and Community Development Plan, County of Hawaii, 1992; Na Ala Hele Trail and Access Program, Hawaii Department of Land Naiural Resources, 1991. 
that other uses-such as homesteading and cultural conservation-be considered (Matsuoka et al. 1995).

According to the DHHL, additional developments such as transmission lines through home lands, calculated to benefit nonresidents and located in areas where existing lines are sufficient for current or projected use, would not necessarily benefit Native Hawaiians. Hawaiians have expressed concerns to the DHHL about the potentially harmful health effects of long-term exposure to electric and magnetic fields (EMF) and about the increased likelihood that valuable archaeological resources could be damaged directly during construction or indirectly by the construction of new maintenance roads in formerly inaccessible areas. They have also expressed concern that construction could impede scheduled developments, like those projected for Kawaihae on the island of Hawaii (see Table 1). According to the DHHL, "some Native Hawaiians have voiced strong opposition to [projects involving] the development of geothermal energy on religious grounds" and "have already voiced opposition to [the possibility of a] the transmission line crossing Kahikinui (on the island of Maui)" (DHHL 1993). Demonstration of a clear benefit to Native Hawaiians is required for a project to proceed on Hawaiian Home Lands. This demonstration of benefit can entail the use of easements or exchange of land (MacKenzie 1991).

Prior to the Hawaiian Homes Commission Act, the Hawaiian government also divided land holdings from 1848 until 1855 by award and purchase. Hawaiians who could verify their claim's authenticity acquired ownership of their kuleanas, or farms, by Land Commission Awards. Kuleana owners and tenants acquired protected rights of access, rights to gather resources, and the right to use running water on the awarded property-rights that were subsequently tied to the parcel of land. Anyone unable to establish a claim could still purchase plots of government land. The government sold these parcels, known as land grants, individually or through homestead acts. At the end of this period of land distribution, four million acres of land still belonged to the Crown, to the Hawaiian government, or to various chiefs. In contrast, the common Hawaiian population received less than 30,000 acres (Parker 1989).

Some Hawaiians subsequently sold these properties, but others handed them down within families and these lands remain in use by Hawaiians today, sometimes by means of complicated ownership arrangements. For example, 30 individuals (some of whom live in Hawaii and some of whom live on the mainland) have joint ownership of an 85-acre parcel in South Maui (Matsuoka et al. 1995). In the Puna District in 1880, Hawaiians maintained small-scale traditional farms, and other settlers invested in commercial properties like coffee plantations on approximately three dozen land grants (Burtchard and Moblo 1994). Residents of the Puna District on the island of Hawaii still cultivate dryland kalo (a staple in the traditional Hawaiian diet) on tracts they own within the Kamaili Subzone. On Maui, the government made more than 150 grants in the District of Makawao, many of which are owned by descendants today. Current owners of land grants in Kanaio and Kaupo use land that is close to the study area for recreation and subsistence. Continued use of these lands is important both for subsistence activity and for educating young Hawaiians about traditional customs (Erkelens 1995; Matsuoka et al. 1995). However, decisions 
regarding legal rights of access, gathering, and use of running water by Native Hawaiians depend on individual judicial rulings regarding claims for traditional uses within a particular ahupua'a (see Lam 1989). At an early stage of project planning, developers should consider whether Land Commission Awards, individual land grants, and/or ceded lands (including Hawaiian Home Lands) would be involved in proposed projects.

\subsubsection{Access}

In Hawaii, "access" refers to trail systems or to rights of entry protected by state law. Trails run parallel to the shore from one ahupua'a to another, or they run mauka to makai (from mountain to sea) from upland areas traditionally used for cultivation, hunting and gathering, and worship to areas that once were coastal settlements and today are still important for fishing. Trails are an important means of access; they are also important remnants of the past, as on Maui where the original coastal Piilani Trail (c. 1450) was later integrated into the Hoapili Trail and the Old Government Road during the 19th century. On Maui, the study area "lies in an area that is crisscrossed by many historical trails, and therefore should be considered sensitive" (Meller 1994). Coastal and low-elevation trails heading mauka are located at Ahihi-Kinau, at Nu'u Landing near Huakini Bay, and at many points along the coast in between. On the island of Hawaii, the Ala Kahakai-Awini Trail that extends from the southern border of Volcanoes National Park to Upolo Point is under consideration for inclusion in the National Park System as a scenic historic trail. Hawaiians also enter the Kilauea Subzone and the Kamaili Subzone in the vicinity of hunting and gathering areas via old trails (Meller 1994, Matsuoka et al. 1994). Table 2 summarizes information from the $\mathrm{Na}$ Ala Hele Trail and Access System to identify trails in the study area. This list includes trails that have been identified by the Na Ala Hele program but does not necessarily include all significant trails in the areas. See Sect. 3 and Figs. 4 through 6 for further description of historic and culturally significant trails.

Kuleana tenants are individuals who retain traditional ties to the land under state law by residing on kuleanas, or farms, acquired as Land Commission Awards during the mid 19th century (see Sect. 2.1.1). They maintain unique access rights to the use of certain trails, as well as public access rights to the shoreline. Kuleana tenants retain certain gathering rights, the right of access to their parcels of land whether trails that once led to them are still in use or not, and the right to use sources of running water on the landlord's property. Under the state constitution and Sect. 7 . 1 of the Hawaii Revised Statutes, Native Hawaiians have "... a right to drinking water, and running water, and the right of way ..." in the ahupua'a (a traditional unit of land) in which they reside (Lam 1989; MacKenzie 1991). The law regarding access from mountains to beaches, and between ahupua'a or districts, is less well defined, though such rights can be established on a caseby-case basis.

Residents in the Puna District of the island of Hawaii and on South Maui continue to use parcels of land that have been handed down in their families; some plan to homestead on land grants. Other residents in both areas cite the importance of maintaining general access to 
Table 2 Rural, wild, and sensitive trails

\begin{tabular}{|c|c|c|c|c|}
\hline Island & Trail name & Location & Description & Use \\
\hline \multicolumn{5}{|c|}{ Priority and demonstration trails } \\
\hline Hawaii & $\begin{array}{l}\text { Ala Kahakai-Awini Trail } \\
\text { Pu'u 'O'o Horse Trail }\end{array}$ & $\begin{array}{l}\text { West } \\
\text { South central }\end{array}$ & $\begin{array}{l}\text { Coastal } \\
\text { Rugged }\end{array}$ & $\begin{array}{l}\text { SRC } \\
\text { SRC }\end{array}$ \\
\hline Maui & $\begin{array}{l}\text { Hoapili Coastal Trail } \\
\text { Nakuli Trailc }\end{array}$ & $\begin{array}{l}\text { South central } \\
\text { Southeast }\end{array}$ & $\begin{array}{l}\text { Coastal } \\
\text { Rugged }\end{array}$ & $\begin{array}{l}\text { SREC } \\
\text { H }\end{array}$ \\
\hline Lanai & $\begin{array}{l}\text { Hulopoe-Kaunolu Coastal Trail } \\
\text { Awehi Trail }\end{array}$ & $\begin{array}{l}\text { South } \\
\text { Southeast }\end{array}$ & $\begin{array}{l}\text { Coastal } \\
\text { Rugged }\end{array}$ & $\begin{array}{l}\text { SHC } \\
\text { SH }\end{array}$ \\
\hline Molokai & $\begin{array}{l}\text { Puu Kolekle-Kamalo Trail } \\
\text { Maunahui-Makakupaia Loop } \\
\text { Ke Ala Pupu i Molokai Trail System }\end{array}$ & $\begin{array}{l}\text { Central } \\
\text { Central } \\
\text { West }\end{array}$ & $\begin{array}{l}\text { Rugged } \\
\text { Rural } \\
\text { Coastal }\end{array}$ & $\begin{array}{l}\text { SH } \\
\text { SER } \\
\text { SRHC }\end{array}$ \\
\hline \multicolumn{5}{|c|}{ Other trails and trail segments } \\
\hline Hawaii & $\begin{array}{l}\text { Hummu’ula Road } \\
\text { Pu’u ‘'o Trail } \\
\text { Pu’u ‘O'o-Waimea Route } \\
\text { Lapakahi-Paoo Trail } \\
\text { Koaeae Mauka-Makai Trail } \\
\text { Kawaihae-Puu Hue Trail } \\
\text { Kawaihae-Hoepa Trail } \\
\text { Kawaihae-Kawaihae Uka Trail } \\
\text { Old Kawaihae-Waimea Road } \\
\text { Waikoloa Stream Trail } \\
\text { Imiola-Mana Trail }\end{array}$ & $\begin{array}{l}\text { Central } \\
\text { Central } \\
\text { Central } \\
\text { Northwest } \\
\text { Northwest } \\
\text { Northwest } \\
\text { Northwest } \\
\text { Northwest } \\
\text { West central } \\
\text { West central } \\
\text { Central }\end{array}$ & & \\
\hline Maui & $\begin{array}{l}\text { Kalua O Lapa Trail } \\
\text { Kanaio Beach Road } \\
\text { Waiopai Trail } \\
\text { One Kiawe } \\
\text { Nuu Bay and Landing }\end{array}$ & & & \\
\hline Lanai & No trails identified & & & \\
\hline Molokai & No trails identified & & & \\
\hline Oahu & No trails identified & & & \\
\hline
\end{tabular}

Note: See Figs. 1-3 for precise locations of trails an island of Hawaii and Maui; see also descriptions of some trails in Sect. 2.

- $\mathrm{S}=$ scenic, natural interest; $\mathrm{E}=$ educational activities; $\mathrm{R}=$ recreational; $\mathrm{C}=$ cultural, historical interest; $\mathbf{H}=$ hunting.

'Proposed trails.

Sources: DLNR 1991b, 1993; Townscape, Inc. 1992. 


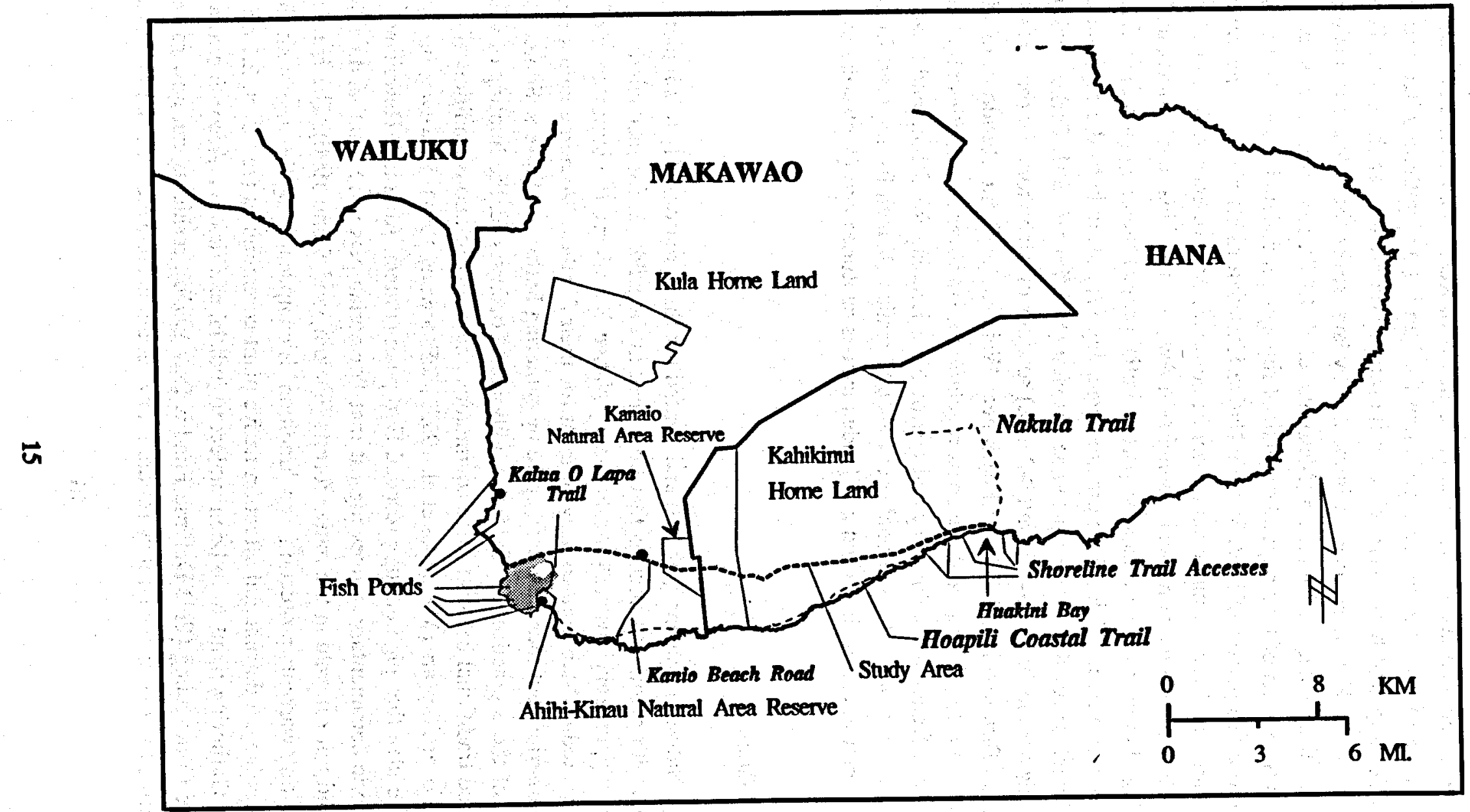

Fig. 6. Selected Hawaiian homelands, major trails, and other culturally sensitive areas on southeast Maui. Source: Hawatian Home Land Maps, Hawaii Department of Hawaiian Home Lands, 1992; Na Ala Hele Trail and Access Program, Hawail DLNR, 1991; DHM Planners, Hawailan Fish Pond Study, 1990. 
undeveloped areas for recreation and subsistence uses. Residents of Maui experience frustration when refused access to traditional gathering areas and sacred sites on ranch lands, or permission to cross ranch lands to reach a coastal site (Matsuoka et al. 1995). Residents of the Puna District emphasize the importance of access to undeveloped areas for hunting and gathering because real estate and industrial development have encroached so thoroughly on areas near the coast. Those who once lived in places like Kalapana, recently inundated by lava, stress their desire to maintain access to land to which they will someday return (Matsuoka et al. 1995). However, decisions regarding legal access to parcels of land depend on judicial rulings in individual cases on the rights historically attached to those parcels of land. Specific Native Hawaiian rights are most clearly tied to Hawaiian Home Lands and Land Commission Awards; however, developers should consider any potential legal issues associated with Land Commission Awards, individual land grants, and/or ceded lands (including Hawaiian Home Lands) as part of initial project planning (see Sect. 2.1.1).

Shoreline access is a public right, since private ownership extends only to the high-water mark, and Native Hawaiians consider unobstructed access vital (MacKenzie 1991, Parker 1989). Shorelines in the study area include 1.6-3.2 km (1-2 mile) sections of Mahukona Harbor, Hawaii; Huakini Bay and Ahihi Bay, Maui; and Bellows Beach near Waimanalo, Oahu. Residents of Maui use existing trails between the highway and the coast regularly for subsistence activities all along the southern coast. They frequent Huakini Bay and nearby Nu'u Landing for fishing and boat launching. The latter is an important traditional site; today, Hawaiians launch fishing craft from the same spot where their ancestors launched and landed canoes centuries ago (Matsuoka et al. 1995).

\subsection{Gathering and Hunting}

Traditionally, Native Hawaiians gathered and hunted for three reasons: (1) to supplement a subsistence lifestyle with plants and animals that flourished in the wild, (2) for medicinal purposes, and (3) to support religious customs. For many Native Hawaiians, the importance of these activities persists today. Men hunt to provide meat for their families. Women conduct most of the subsistence gathering, but men also participate by gathering herbs and flowers. Some disagree whether all of these practices are indeed "traditional." For instance, the hunting of wild pigs can be considered traditional because some communities have a continuous tradition of hunting pigs for well over 50 years (Matsuoka et al. 1995; McEldowney 1994). However, no evidence supports the idea that pig hunting preceded European contact. Although Hawaiians introduced pigs, historic documentary sources suggest that Polynesian pigs were small and easily domesticated; they did not run wild in the native forests (Cuddihy and Stone 1990). The issue of whether wild pig hunting warrants protection as a "tradition" is complicated by the argument that today's large feral pigs have a detrimental effect on native plant communities (see Sect. 2.1 on traditional culture). Gathering rights have been subject to judicial clarification. According to a recent state Supreme Court ruling (Pele Defense Fund v. Paty 1992b), residents can now gather in an ahupua'a abutting the one in which they reside. Many residents cultivate traditionally used 
plants near their homes. However, in the Puna District, Hawaiians still gather herbs in the wild, and they also gather flowers that many describe as being unusual in color, shape, and fragrance. Some believe that the plants growing in Puna's rainforest are "fed by unique and spiritual elements" and, to please the gods, traditional gatherers sometimes clear patches of land to encourage the growth of desirable plants, like maile (Matsuoka et al. 1995). Hawaiians used to gather herbs along the coast of Puna, but recent land developments have seriously reduced their availability. Some Hawaiians now gather herbs in the former. Wao Kele O Puna forest reserve, where they can still be found. Hawaiians also pick maile and lama (flowers) in the Kaimu forest and in Wao Kele O Puna for use in celebrations, and as "ho'okupu" (offerings). Hawaiians living outside Puna sometimes specifically request flowers from this area for use on special occasions (Matsuoka et al. 1995).

On South Maui, dryland grass is the most prevalent vegetation, but there are also imported and native species of bushes and trees, including traditional native Hawaiian plants used in healing. Native vegetation is prevalent on Maui in kipuka (isolates) located in the lava flow reserve at Ahihi-Kinau and can be found all along the midlevel slopes. Rare and endangered species are located on the east side of Luala'lua Hills and in Manawainui Gulch and are probable in other areas. In the Kahikinui district of Maui, Hawaiians who practice la'au lapa'au (traditional medicine) gather herbs regularly and plan to reestablish a traditional herbal medicine school in the area (Matsuoka et al. 1995). Cattle and feral goats, prevalent in South Maui, are largely responsible for the characteristic soil erosion and lack of vegetation. As a result of ranching, native plants have dwindled, and the forest line has retreated dramatically since the 1930s; conservation of remaining plant resources is therefore especially important. Gathering occurs sporadically along the midlevel slopes of South Maui. Other areas where gathering is important include the southern portion of Kilauea Subzone and the north and southern portions of Kamaili Subzone in the Puna District (Matsuoka et al. 1995).

Hawaiians, Portuguese, and other local residents consider hunting wild pigs, sheep, and goats to be "part of the very fabric of the traditional island lifestyle" (Buck 1993). With the decline in sugar production on the island of Hawaii, residents depend increasingly on the ocean and the forest for food and recreation (see Fig. 4). In the Puna District and on South Maui, hunters supplement their largely carbohydrate diet with protein from wild pigs, goats, and cows as well as fish and seafood. Approximately 150 Hawaiian families who were displaced by the creation of Volcanoes National Park have been issued permits allowing them to fish and hunt within the park (Matsuoka et al. 1995). Hawaiians rely on traditional protocol to maintain equitable hunting, fishing, and gathering arrangements and to ensure future regeneration of the stock. Ideally, hunters or gatherers never take more of a resource than they need, and they share their take with the 'ohana (family) and community. They hunt within informally agreed upon boundaries. Unfortunately, traditional conservation practices are sometimes violated in the Puna District by newcomers and even by longtime local residents who recognize that available resources have dwindled in the wake of housing developments and agricultural and industrial clearing. Rather than compete, some hunters prefer to hunt where wild animals are still plentiful. Those Hawaiians 
most interested in adopting modern ways claim that some residents over romanticize the "old ways" and exaggerate the present role of subsistence in Hawaiian community life. Others continue to depend heavily on local hunting. They maintain that the undeveloped rainforests of the Kilauea Subzone, while nearly inaccessible to the hunter, provide a haven for the wild animals-a place for them to bear young and rejuvenate the stock available to hunters at lower elevations (Matsuoka et al. 1995).

Wild pigs also endanger sensitive native forest habitats, and many environmentalists advocate fencing or eradication-measures that hunters and some local communities resist. Hawaiian gatherers also blame wild animals for the destruction of traditionally valued plant resources, but they advocate continued hunting as the most viable means of control. As a compromise, the state of Hawaii is experimenting with enhancing the effectiveness of public hunting as a means of pig control. A master agreement outlining cooperative strategies for control of wild animals is planned by the National Park Service (NPS), the U.S. Fish and Wildlife Service, the state of Hawaii, and Bishop Estate for Hawaii Volcanoes National Park (Buck 1993, Matsuoka et al. 1995, NPS 1993). Parts of the study area in which hunting is important include the southern and western portions of Kilauea Subzone and the northern and southern portions of Kamaili Subzone in the Puna District. Hunting occurs primarily between the midlevel slopes and . the coast of South Maui and at higher elevations beyond the project area (Matsuoka et al. 1995).

\subsection{Shoreland and Near-Shore Marine Resources, and Submerged Lands}

Now, as in the past, Native Hawaiians use the shoreline to fish; to gather limu (seaweed), 'opihi (limpets), and other ocean resources; and for recreation (MacKenzie 1991; Abbott 1992; Wyban 1992). All submerged lands, including lands under navigable waters, public lands held in trust by the state, and coastal fishing is generally open to the public. However, a few coastal fishing areas are protected by vested konohiki fishing rights, a system unique to Hawaii that gives native landlords authority over when and how heavily an area is fished. Most of these rights expired around 1900. While a few hundred still exist, the state has no record of konohiki rights to any of the study areas. Nonetheless, Hawaiians and other local residents fish and gather ocean produce along all public coastal areas of the Puna District and South Maui. Residents of the Puna District gather crabs, sea snails, limu, and shrimp along the rugged lava shoreline. Some kinds of limu and opae ula (small red shrimp) are found in the brackish water of anchialine ponds. Nearshore fishing is also plentiful off the coast of Maui, where trails, land marks, seabirds, and weather conditions are all important contributors to the fisherman's trade. Because of its NAR status, traditional gathering is restricted in Cape Kina'u. However, Hawaiians still value its anchialine pools because they support opae ula and a species of shrimp that exists in few other places in the Pacific region (Matsuoka et al. 1995; Maciolek 1986). Other fish ponds and modified natural pools of archaeological worth are located north of Ahihi-Kina'u at Ahihi Bay and south at La Perouse Bay (see Fig. 6). 
Prehistoric Hawaiians were the most skilled of all Polynesian peoples at constructing fishponds, enclosures of water in which fish and other aquatic organisms were raised and harvested (Wyban 1992). Both man-made and natural fishponds remain on several of the islands and provide the focus for a resurgence of interest in traditional fishpond aquaculture in Hawaii, particularly on the island of Molokai. Hawaiians also used and sometimes modified natural pools and ponds along rocky shores, particularly along the rugged volcanic coastlines of the islands of Maui and Hawaii (see Figs. 4 and 5). Spring-fed ponds provide potable water and places for bathing. Anchialine pools contain brackish water from tidal action and high waves. Hawaiians constructed fishponds as early as 1000 A.D. and continued to build them until the 1820 s; however, their use declined in the early 1900s (Wybau 1992). Today, as in the past, Native Hawaiians raise and sell fish and gather opae (shrimp), crabs, and some types of limu (seaweed). Natural tide pools at Waiopae, Puna, located near the Kapoho Subzone, are rich in edible seaweed, marine shells, shrimp, young fish, sea urchins, and sea cucumbers (Wyban 1992; DHM Planners, Inc. 1989; DHM Planners, Inc., 1990).

Parts of the study area include anchialine ponds and the lava shoreline near the Kapoho Subzone on the island of Hawaii and at Huakini Bay, Nu'u Landing, and Ahihi Bay on South Maui. As with hunting, overharvesting has applied additional pressure to dwindling resources along the Puna coast, and fishing has become more difficult to pursue on South Maui during recent years because of restricted access to resort and ranch lands (Matsuoka et al. 1995). Table 3 lists fishponds and anchialine pools in the study area.

\section{Water}

Section 174C-101 of the State Water Code of 1974 protects common law rights and customary Native Hawaiian water rights for residents of an ahupua'a. One provision of the code allows water rights to be transferred for the public good. However, elsewhere the code indicates that the provision cannot be used intentionally to abridge or deny Native Hawaiian rights (MacKenzie 1991).

Historic records fail to indicate that geothermal pools were numerous or that Native Hawaiians considered them particularly valuable, but oral accounts indicate that steaming, induced sweats, and immersion in fresh or salt water traditionally were important healing processes. Water had spiritual significance, as well. The rains and fresh waters of Puna enriched the island's water table and signified renewal and growth to Hawaiians. Volcanic steam in the forest was said to be a manifestation of Pele. Hawaiian charts indicate that Kaneikawaiola, Hawaiian god of flowing and fresh water, protected the subsurface waters of Puna's easternmost region, including warm pools that were sacred bathing places of Pele (Matsuoka et al. 1995). For some residents and frequent visitors from other islands, these traditional beliefs form the basis for contemporary religious practice. In 1990, worshippers of Pele "declare[d] their use of the aquifer, pool, and spring waters and the volcanic steam ... to perpetuate and practice traditional Hawaiian customs and beliefs of Pele (Pele Defense Fund 1990)." These practitioners prefer not to reveal the locations of sacred 
Table 3. Fishponds and anchialine ponds

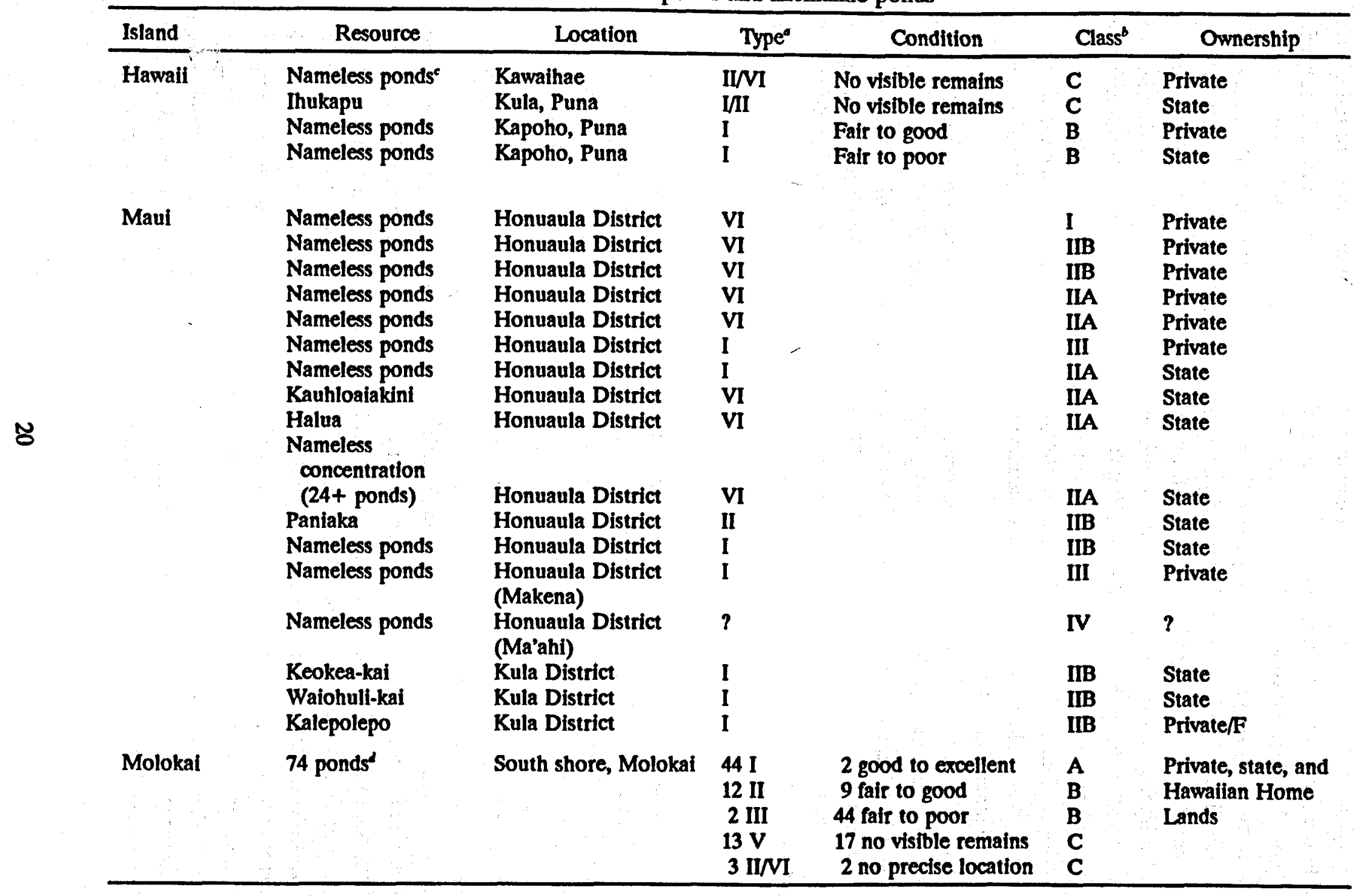


Types of fishponds:
I Loko Kuape-fishpond with side or sides facing the sea
II Loko Pu'vone-isolated shore fishpond with sand ridge parallet to the coast (anchialine)
III Loto Wai-inland freshwater fishpond
IV Loko i'a kalo-inland fishpond utilizing irrigated taro plots
V Loko 'Ume'ikt-rishtrap, similar to Type I
VI Katheka and Hapunapuna-natural pool or holding pool (anchialine)
bCassification of eligibility for listing in National Register of Historic Places (NRHP): A-Resource meets at least three criteria for listing in the NRHP
B-Resource meets three or less criteria for listing in the NRHP
C-Resource does not meet criteria for listing in the NRHP

Tait of the known anchialine ponds are located on the island of Hawail. The resources listed (and additional small ponds atong the coast such as those at Cape Kumukahi in the Puna District) are not located within the GRZs, but passage of water through porous lava openings and tubes could connect shoreline resources with the Kapoho subzone.

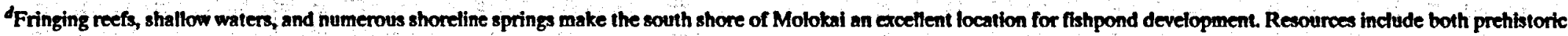
sites and contemporary vemures in iraditional aqua calture.

\section{Soureer. DHM Planners, Inc. 1989, Wyban 1992}

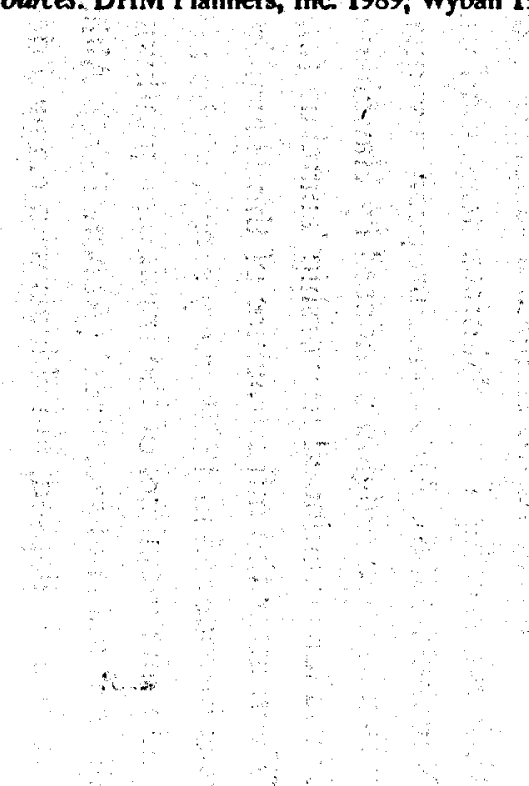


sites, citing the misuse of steam baths and secluded beach areas by newcomers insensitive to their cultural and spiritual significance (Matsuoka et al. 1995).

Any plans for future development of the GRZ should consider all uses of surface water and steam in the vicinity. Under Section 174C-101 of the state Water Code, Native Hawaiians residing in an ahupua'a containing waters used for traditional purposes could claim that denial of access to those waters constituted an abridgement of rights. In addition, the ruling in McBryde Sugar Company v. Robinson, a case heard before the state Supreme Court in 1973, asserted a public trust doctrine. That ruling indicated that grantees do not receive full right to normal surplus waters with their land grants, and that normal surplus waters are available to other users. Based on this ruling, "it could be argued that rights to geothermal water were also reserved to the people, along with other rights concerning water specified in Section 7-1 of the Hawaii Revised Statutes" (Kamins 1980; MacKenzie 1991). However, the Water Code also allows a permit for restricted use of a water source to be issued based on a determination of the public good, for which a case could be made if only a few residents claimed denial of cultural and religious rights. Whether the state Water Code or other state laws on customary rights would protect the rights of a few to use water in the GRSs would ultimately depend on a court ruling (Kamins 1980).

\section{NATTVE HAWAIIAN REIIGION AND BURIAL PRACTICES: RIGHTS AND CUSTOMS}

\section{Native Hawaiian Religion and Spirituality}

Traditional forms of Hawaiian worship closely linked nature and spirituality. Throughout the prehistoric, or pre-contact, period (ca. 300-1778 A.D.), Hawaiians invested sacrality in plant and animal life and in natural features. They believed the Earth to be permeated with spiritual forces, all of which were interconnected. Based on this traditional concept, contemporary Hawaiians still insist on the importance of synergistic effects. They assert that "a cycle of change or an entire system . . . becomes vulnerable because one part of it is damaged" (Matsuoka et al. 1995).

Hawaiians worshipped a variety of gods and goddesses at heaiu (religious temples or shrines), ranging from elaborate stone platforms to simple earthen terraces (Dudley 1990; Kanahele 1986). Although European missionaries disrupted and finally eradicated support for the official native religion mandated by Hawaiian chiefs and royalty in the early 19th century, Native Hawaiians continued to worship 'aumakua (ancestor, or family, gods) during the historic period. "Even after the infrastructure of the Hawaiian religion was dismantled in 1819 and Christianity was introduced in 1820, many accepted the new god but also continued to honor their 'aumakua and some members of the traditional pantheon-deities like Pele and her consort Kamapua'a, who did not deinand sacrifices" (Abbott 1992). Although adherence to official Hawaiian religious practices collapsed, individuals who claimed descent from 'aumakua of certain deities, like Pele, 
continued to maintain their ancestral beliefs and practices within the family (Abbott 1992; Nimmo 1992; Kanahele 1986).

Today, it is not uncommon for Hawaiians to identify themselves as Christians but also to hold another set of beliefs consistent with traditional Hawaiian spiritual beliefs. In the Puna District, traditional hunters, fishermen, and gatherers pray routinely to Hawaiian gods as a ritual part of subsistance activity. They believe gods to be represented by natural elements: Moana (ocean), La (sun), Ua (rain), 'Aao (clouds), and Honua (land). They pray for protection from the elements, for help finding their way, and for productive hunting, fishing, and gathering expeditions. They thank the gods for their help and honor them by sharing resources and taking only what they need. Hawaiians sometimes clean an area or leave ho'okupu (symbolic offerings) to pay respect for deities. Some interact directly with 'aumakua by honoring their familiar animal forms: mano (shark), mo'o (lizard), or pueo (owl). Along with respecting 'aumakua, those familiar with South Maui also watch for special atmospheric signs and weather conditions: "The rainbows are the herald of the porthole to the other dimension. And the color combination indicates what will be granted to you" (Matsuoka et al. 1995).

Few estimates are available on numbers of Native Hawaiians who adhere to traditional spiritual practices, but those statistics that do exist suggest that traditional practice is widespread on some islands. In a survey conducted in 1970,30\% of all residents in the state who indicated a religious preference marked "other," a category composed of adherents not reporting a church membership and practitioners of "indigenous religion." On Molokai, with a population roughly half Native Hawaiian, the percentage ran as high as $\mathbf{5 1 \%}$ (University of Hawaii 1983). Ka Ohana O Kahikinui, a group of Hawaiians in South Maui, seek to revive cultural and religious activities in Kahikinui, a locale linked in legend with ancestors and ancient navigators. Likewise, in the Puna District, some Hawaiians still take the legendary meanings of Puna, as the "well-spring" - a sacred place of renewal and growth-very seriously. For instance, worshippers of the volcano goddess, Pele, (not all of whom are Native Hawaiian) seek to revive and promote spiritual practices associated with Pele and Kaneikawaiola, Hawaiian god of fresh water and guardian of the Pele clan (Matsuoka et al. 1995). Citing the American Indian Religious Freedom Act (AIRFA) of 1978, these religious practitioners seek to protect their access to undeveloped areas of the Puna District near the Kilauea rift zone.

The AIRFA requires federal agencies to consult with native religious leaders, including Native Hawaiians, on the potential effects of proposed federal projects on the free exercise of native religions. If negative effects are shown to be likely, then the agency must show that compelling governmental interests are at stake before it can proceed with the project (Sharples and Salk 1988). Citing AIRFA, worshipers of Pele have expressed concern that any future development of geothermal resources would place undue burdens on their ability to freely exercise their traditional religion, since drilling into the volcano represents a depletion of. Pele's life blood and energy. However, the state ruled in Dedman v. Board of Land and Natural Resources (1987) that the plaintiffs had failed to demonstrate that religious ceremonies had to be held in an area proposed for geothermal development, or that government action had directly 
impinged on Native Hawaiian religious practice by causing irreverence toward religious beliefs. This state decision referred to an important federal Supreme Court case, Lyng v. Northwest Indian Cemetery Protection Association (1988), in which the court constrained its ability to pass judgment on religious rights issues to situations where government conduct coerces violations of religious beliefs or penalizes individuals for their religious beliefs. In the aftermath of this ruling, most scholars of Native American religious freedom agree that AIRFA has afforded little real protection for traditional religious practice, and amendments to strengthen the protective capabilities of AIRFA are presently under consideration (MacKenzie 1991; Vecsey 1991). The more broadly defined Religious Freedom Restoration Act (RFRA) of 1993 now offers additional protection. This act requires the federal agency to demonstrate a compelling need before proceeding with a project known to interfere with the free exercise of religion. Although Article XII, Section 7, of the Hawaii State Constitution also affords protection for customary religious practice, plaintiffs appearing before the state Supreme Court in 1987 did not cite it, probably because they did not claim to live in the ahupua'a where ceremonies were held (MacKenzie 1991). However, a ruling in 1992 that Native Hawaiian rights may extend beyond the ahupua'a in which a Native Hawaiian resides, provided such rights have been exercised traditionally, may extend plaintiffs' ability to cite the state constitution in such cases in the future (Pele Defense Fund v. Paty 1992).

\section{Pele in Mythology and Contemporary Belief}

Traditionally, Native Hawaiians believed that Kilauea volcano was inhabited by a family of fire gods presided over by the goddess Pele, who governed and directed lava flows. "The Pele myth is believed to have developed in Hawaii where it is closely associated with 'aumakua worship of the deities of the volcano, with the development of the hula dance, and with innumerable stories in which odd rock or cone formations are ascribed to contests between Pele and her rivals, human or divine" (Beckwith 1970).

Worship of Pele was most prevalent in those districts of the island of Hawaii, like Ka'u and Puna, where residents witnessed volcanic action firsthand (Nimmo 1992). However, while Pele worshippers concentrated on the island of Hawaii, traditional myths about Pele were told throughout the Hawaiian islands. The body of myths about Pele's birth and search for a home in Hawaii, her family relations and encounters with others, and her role in shaping geological formations was a "major myth cycle of Hawaii and one of the most elaborate found throughout Polynesia" (Nimmo 1992). Contemporary interest in Pele ranges from revitalization of traditional chants and hula to perpetuation of folklore about "Pele sightings." Many people-native residents and tourists alike-share a fascination with Pele. Twice during this century, organizations have formed to "improve" or to "protect" Pele's surroundings, depending on the environmental ethic of the times. In the 1920s, Hui o Pele funded improvements to the Kilauea area. Currently, the Pele Defense Fund opposes geothermal and other development in the Puna District as a threat to Pele and to the quality of the environment (Nimmo 1986; Nimmo 1992). However, neither of these 
organizations has had consistent support from a majority of Native Hawaiians living in the immediate area (Puna Aloha Aina 1992). While the number of local native residents involved with the Pele Defense Fund is unknown, many Hawaiians profess spiritual linkages to the land and oppose large-scale development (Matsuoka et al. 1995).

Contemporary Hawaiians' attitudes toward Pele vary according to whether they worship Pele or respect, rather than revere, Pele. As represented by the Pele Defense Fund, worshippers of Pele are a mixed group, including both Native Hawaiian and non-native residents and visitors. They profess to believe that all areas of volcanic activity constitute the abode and the physical body of Pele. "Geothermal development involves the penetration of Pele's body and the withdrawal of Her energy. This is literally a penetration of Her body, and a diminishment of Her power" (Pele Defense Fund 1992). They fear that, without physical manifestations of Pele's presence, a "critical link between active worship and a living god would spell doom for Hawaiians." Having inherited ancestral beliefs, they believe it their duty to pass those beliefs on to successive generations. Some individuals feel they are sanctioned to be caretakers of ancestral lands (Matsuoka et al. 1995). Pele worshippers tend to be participants in cultural revivalist and environmentalist movements, and they represent an alliance characteristic of rural areas faced with industrialization (Linnekin 1983; Schnaiberg 1986). To the Hawaiians within this group, oral traditions and family rituals have kept the worship of Pele alive, and contemporary worship reaffirms genuine traditions.

To other Hawaiians, the effort to revive Pele worship seems misguided; they remain skeptical that chants and rituals formulated long after the pre-contact period are truly "authentic." Some Hawaiians conclude that nothing in their traditions prevents them from attaching a utilitarian rather than a spiritual value to geothermal resources, especially if harnessing geothermal power safely might benefit Native Hawaiians. (Puna Aloha Aina 1992;

Kawikuamookekuaokalani-Henry 1992). However, a study of Native Hawaiians in the Puna study area revealed that, in general, Hawaiians "believe in and respect Pele (Matsuoka et al. 1995)." Even those who do not openly worship Pele today still adhere to a tradition of respect for Pele as a manifestation of natural volcanic forces that radically alter the local landscape and upon which human agency has little effect. To these Hawaiians, tampering with Pele is risky, if not unwise (Lachman and Bonk 1960; Piianaia 1986; Langlas 1990).

\section{Native Hawaiian Burial Rights and Practices}

To prehistoric Native Hawaiians, na iwi, or the bones of the dead, played a significant role in a number of beliefs and practices concerning death and immortality, particularly in the initial period after death when the bones were prepared for burial. Regardless of their religious beliefs, contemporary Hawaiians continue to take these traditional beliefs very seriously. According to common law, descendants retain certain rights regarding human remains and funerary objects. Removal of a body is to be avoided whenever possible, and many Hawaiians accept exhumation 
only as a last resort. Adequate planning to avoid sensitive sites is preferable to mitigation once a route or project development has been selected (MacKenzie 1991).

Recent passage of state and federal laws affords considerable protection to burial sites. The state's historic preservation law (codified as Hawaii Revised Statutes, Chapter 6E, 1976) was amended in 1988 to include Act 265, which establishes provisions for the discovery of prehistoric and historic burial sites. The act requires that the Office of Hawaiian Affairs be contacted in the event of a discovery, and that attempts be made to contact lineal descendants. This amendment made Hawaii's Historic Preservation Act one of the most protective state laws in the nation. Another amendment, Act 306, requires developers of any state project or private project requiring a state permit or license to notify the State Historic Preservation Division (SHPD) in the event that human burials are discovered. If an archaeological assessment reveals evidence of burials, the appropriate burial council must be notified and given $\mathbf{3 0}$ days to comment on preserving or relocating remains (MacKenzie 1991; DLNR 1991a). Burial sites are discussed further in Sect. 3.2.

The National Historic Preservation Act (NHPA) and the Native American Graves Protection and Repatriation Act (NAGPRA) encourage preservation in situ of archaeological sites, including burials and associated cultural items (funerary objects, sacred objects, objects of cultural patrimony) on federal and tribal lands (McManamon 1992). NAGPRA specifies that consultation with Native Hawaiians must precede federal activity that could result in the excavation of burial remains on federally managed lands. Study areas subject to NAGPRA as well as state law include the Kawaihae Home Lands on Hawaii and the Kahikinui Home Lands on Maui, since Hawaiian home lands were federally supervised until 1959 and are still subject to federal overview. Lava tube burials are known to exist in the Kahikinui Home Lands of Maui in the study area. Bellows County Beach at Bellows U. S. Air Force Base would also be subject to NAGPRA. The Air Force cultural resources plan for Bellows Air Force Base requires that all NAGPRA consultations be coordinated with the existing Air Force cultural management program (Biosystems Analysis, Inc. 1993). Additional places in the study areas subject to NAGPRA include property at Pu'ukohola Heiau National Historic Site and at the Pohakuloa Training Area, managed by the U.S. Air Force. Other areas in which detection of burials is likely include the GRSs, the North Kohala coast of the island of Hawaii, and other areas of South Maui.

\section{PERSISTENCE OF CORE CULTURAL VALUES}

Regardless of their differences, many Native Hawaiians share a commitment to maintaining traditional ways of life, particularly those that perpetuate aloha aina (respect for the land) and malama aina (nurturing the land) (Minerbi et al. 1993). Many also extend the principle of malama to include the revival of wahi pana, sacred or culturally significant Hawaiian places. They believe in sharing resources to sustain the 'ohana (extended family) and in promoting regeneration of ocean and forest resources. However, under the pressure of dwindling resources and outside influences, these forms of traditional reciprocity tend to break down (as in the case of pig hunting in the Puna District). In this context, scholars debate whether aloha aina accurately 
characterizes Hawaiian heritage or better represents a nostalgic recreation of "tradition" for contemporary use by revivalists (cf. Trask 1993 and Linnekin 1983). Regardless of intent, inhabitants-including prehistoric Hawaiians-have always radically altered the ecology of the Hawaiian islands (Cuddihy and Stone 1990). However, generations of Hawaiians have also nourished a rich oral tradition, vivid with environmental imagery, that forges palpable connections between myth and landscape. They visualize the landscape-plants, animals, weather-as part of a continuum linking their everyday lives inextricably with natural spiritual forces. On Maui, an unobstructed view of the ocean from the upland slope enables one to identify fishing grounds and to evaluate fishing conditions from a distance. In the Puna District, the life cycle of mountain plants is correlated to particular ocean conditions, such as the feeding pattern of sharks (Matsuoka et al. 1995).

Traditions are created and recreated in practice. For that reason, Native Hawaiians consider teaching children cultural principles through "hands on" experience to be of vital importance (Kanahele 1986; Matsuoka et al. 1995). Many Hawaiians return to untouched rural areas for subsistence and recreation, to teach their children Hawaiian ways, or to renew their contacts with the land. In general, they agree that excessive development of these rural areas would be inappropriate. However, some express the concern that young Hawaiians need economic opportunities in rural areas. Consequently, there is some disagreement over whether rural energy and industrial development would be beneficial to Native Hawaiians. For instance, most Hawaiians who frequent South Maui disapprove of any future development of overland power transmission and other visible developments. Some Hawaiians in the Puna District (those living in the immediate vicinity) state their belief that geothermal and other development could promote jobs and economic advantages. Others (living in the immediate vicinity and beyond) are adamantly opposed to further development of untouched areas and consider them a resource of significance to all Hawaiians (Matsuoka et al. 1995: Puna Aloha Aina 1992).

\section{CULTURAL RESOURCES}

Cultural resources are defined in this section as prehistoric and historic archaeological sites; traditional cultural properties; and historic structures, sites, and districts. These resources also contribute to "cultural landscapes." As defined for this report, cultural landscapes are rural areas reflecting the cultural values of people who have used and modified them over long periods of time. They combine assemblages of sites, patterns of use, and transportation networks. Although dynamic (often representing more than one time period) and functional in the present, they can be eligible for inclusion in the National Register of Historic Places (NRHP) and must therefore be considered under the NHPA (Melnick 1984; McClelland 1990). In 1993, the state of Hawaii passed Act 156. an "Act Relating to Cultural Landscapes." This law acknowledged the importance of Hawaii's cultural landscapes and created a task force to explore the designation of such lands (State of Hawaii 1993). 
This section is based on information from secondary literature, existing survey reports, and recent ethnographic and archaeological studies of the study area. It includes: (1) a detailed description of resources in the Puna District GRSs and in portions of South Maui and (2) a generic description of other parts of the study area on the islands of Hawaii, Maui, Molokai, and Oahu.

\subsection{BACKGROUND}

The Hawaiian Islands were settled as early as 300 or 400 A.D. by several migrations of seafaring Polynesian peoples who possibly originated from island groups like the Marquesas Islands, $4000 \mathrm{~km}$ ( 2400 miles) to the southwest. The settlement pattern for each island was determined by a succession of adaptations that prehistoric Polynesians (i.e., Native Hawaiians) and later settlers made to each island's varied environmental conditions (Kirch 1985; Cuddihy and Stone 1990). Windward valleys with substantial rainfall, $200 \mathrm{~cm}$ (80 in.) or more, permanent streamflow, and extensive areas of alluvium produced the best taro pond irrigation systems and yielded the most dependable crops of taro, a chief staple of prehistoric Native Hawaiians. In contrast, some leeward areas received as little as $25 \mathrm{~cm}$ (10 in.) of rain per year. The largely undissected, arid slopes on the leeward side of Maui posed the most problems for agricultural development, eventually proving suitable for dryland cultivation and, later for herding (Cordy and Kaschko 1980; Kirch 1985).

Native Hawaiians viewed irrigated and dryland cultivation as part of a continuum that also included subsistence gathering of marine, coastal, and upland products. "Because the necessities of life stretched from the mountain to the ocean and because waterflow was continuous, it made perfect sense for [Native Hawaiians] to divide their resources into mountain-to-ocean divisions of land, ahupua'a" (Wyban 1992: 88). Ahupua'a were landholdings extending from shallow reefs to inland forests with an agricultural zone in between. They varied widely in width and length depending on availability of resources and on size of population. The typical ahupua'a ranged from 0.3 to $3.2 \mathrm{~km}$ (0.2 to 2.0 miles) in width (Cordy and Kaschko 1980).

Prehistoric Hawaiian adaptations to terrain and weather worked considerable changes in the environment. Deforestation and erosion were natural results of Hawaiian agriculture, which often replaced forests on windward slopes and in valleys with taro ponds, gardens, and habitations. Native Hawaiians introduced new plant and animal species such as taro, bananas, yams, pigs, chickens, and rats to the islands (Cuddihy and Stone 1990). Subsequently, the more drastic impacts of Western industries such as whaling, lumbering, ranching, and cultivation of sugar and coffee accelerated and expanded the scale of environmental change from the late 18th century to the early 20th century (Daws 1986; Cuddihy and Stone 1990). Hawaii's cultural landscapes reflect this pattern of change, as well as the continued importance of traditional land use practices. State Act 156, passed in 1993, identifies categories of cultural landscapes eligible for listing in the NRHP. Of four types identified by the SHPD (State of Hawaii 1993), at least three are represented in the study area: a rural historic landscape (the Parker Ranch on the island of 
Hawaii), a traditional agricultural landscape (fish pond and taro cultivation on Molokai), and a mythical or sacred landscape (volcanic and forested portions of the Puna District). Important elements of these landscapes are described in the following sections. In addition, individual sites discovered in the GRSs on the island of Hawaii and on South Maui may be eligible for listing in the NRHP after completion of further study (see Erkelens 1995; Sweeney and Burtchard 1995).

\subsection{PREHISTORIC AND HISTORIC SITES}

This section first examines prehistoric and historic archaeological sites representative of Hawaiian settlement in areas on the islands of Hawaii, Maui, Molokai, and Oahu that could be subject to development. The section also considers traditional cultural sites, that is, prehistoric or historic sites (often considered legendary or sacred sites, or wahi pana) to which Native Hawaiians continue to have strong traditional ties today. As "traditional cultural properties," some of these sites may be eligible for listing in the NRHP.

This section also identifies historic archaeological sites and historic buildings, structures, or districts that represent non-native aspects of the cultural environment. While state and federal laws mandate special attention to Native Hawaiian culture, some of the same laws (notably, those concerned with historic preservation) cover culture in a broader sense (see the Appendix). In Hawaii, significant sites may represent native culture, non-native culture (e.g., Asian immigration), or various combinations. Historic districts or cultural landscapes are particularly likely to represent the complexities and dynamics of cultural development in Hawaii because of their scale and frequent association with more than one significant time period. For instance, the Parker Ranch is important to understanding the growth of market production in Hawaii and the complexities of Hawaii's ethnic and labor heritage by the mid-19th century; it is also important to understanding the growth of a distinctive Native Hawaiian workforce. Certain resources are identified in Sect. 3.3 as important remnants of Hawaii's 19th-and 20th-century pattern of commerce, agriculture, and industry. Such historic sites and landscapes in the study area include archaeological remains of plantations and railroads and large ranches on the islands of Hawaii and Maui. For more detailed figures and historic accounts of the study areas, see Erkelens (1995) and Burtchard and Moblo (1994).

\subsection{Study Areas}

In general, the greatest density of archaeological sites is near the shore because permanent habitation took place in a coastal zone extending no more than 30 to $90 \mathrm{~m}$ (approximately 100 to $300 \mathrm{ft}$ ) inland. Cultural deposits are shallow, generally less than $1 \mathrm{~m}(3.2 \mathrm{ft}$ ) in depth. Windward coastal and adjacent inland terrain had the greatest amount of reliable rainfall and consequently produced the highest density of features, particularly on older lava flows. The leeward coast became increasingly arid; cultivation took place farther inland where water from rainfall and streams was at times sufficient to irrigate agricultural fields. Sites in this area include 
stone field boundaries, terraced fields, irrigation channels, work areas, and field shelters. The middle zone between areas of coastal habitation and agricultural development supports relatively low site density. Archaeological sites in this zone consist of trails connecting ahupua'a or connecting coastal and upland areas, and shelters (caves, small enclosures, platforms) along the trails. Hunting and gathering took place in forests at higher elevation, but relatively few archaeological remains (e.g., caves used as temporary shelters) indicate the probability of these more transient pursuits (Kirch 1985; Cordy and Kaschko 1980; McEldowney 1979). Historic archaeological sites also provide evidence of later agricultural pursuits, such as coffee and sugar cane cultivation, ranching, and related rock and lumber industries of the late 19th and early 20th centuries (Kirch 1985).

\subsubsection{Hawaii}

The study area includes parts of the South and North Hilo districts located northwest of the Puna District. The Saddle Road runs through the study area north to Waimea (see Fig. 4). The study area includes Kawaihae and the northwest coast of Hawaii up to Makaohule Point at Mahukona Bay. See Figs. 4 and 5 for locations of regional subdivisions and for locations of prehistoric sites, historic sites, and trails described later; see Sweeney and Burtchard (1995) for a detailed depiction of resources in the Puna geothermal resources subzones.

Puna District. The prehistoric settlement and land use pattern summarized for the GRSs is described in greater detail in the archaeological predictive model prepared by IARII in 1994. Based on that model, the following description is a projection of the Puna District's prehistoric development. Until considerable archacological research can be completed, this projection must rely on early historic literature rather than physical evidence. However, evidence from a verification survey, as well as from previous surveys, supports this pattern. For more information, see Burtchard and Moblo (1994) and Sweeney and Burtchard (1995).

Prehistoric and early historic development of Puna. Settlement along the windward coast of Puna may have occurred as early as ca. 300-600 A.D. near Hilo Bay. Moderate population growth may have occurred by 600-1100 A.D., and population density probably increased dramatically between 1100 and 1400 A.D. in both the windward and the drier leeward sections of the Puna District (Burtchard and Moblo 1994). During this period, inland agriculture increased, and markers of social status appeared in ceremonial elaboration, residences, and burials. Between 1600 and 1778 (the date of initial European contact with inhabitants of the Hawaiian Islands), tribal factions began to compete for resources that had become increasingly limited as the population increased. By the early historic period (ca. 1778 and after), villages dotted the shoreline and inland trails crossed the densely wooded interior. These trails provided routes for transportation; access to forest products (birds, pigs, thatching and weaving material, and firewood); and maintenance of kinship networks. By the 19th century, horse trails were prevalent. The route taken by the Wilkes Expedition (1840-1841) can be traced along the Kilauea East Rift 
Zone from Kilauea to Kapoho Crater and back to Hilo; Wilkes encountered taro patches and sweet potatoes at elevations of up to $610 \mathrm{~m}$ (2000 ft)(Burtchard and Moblo 1994).

Land use and the archaeological record. The coastal area near Kapoho Subzone was intensively used during the prehistoric past. Historical sources also suggest agricultural use of old sediment zones on the southeast (seaward) side of the rift slope in both the Kamaili and Kilauea subzones following settlement of the leeward coast; however, the frequency of land use, and consequently the accumulation of archaeological features, would be expected to be less in these subzones (Burtchard and Moblo 1994).

Extensive volcanic activity has occurred on the island of Hawaii over the past 1000 years, and settlement in the Puna District has coincided with a frequently and dramatically changing landscape. This dynamic situation affects the integrity of the existing available record; modern lava flows have covered approximately $25 \%$ of the total study area, obliterating signs of prehistoric land use. Volcanic activity has also shaped the history of land-use practices. For instance, weathered a'a lava provided the most productive agricultural ground, and tube-fed pahoehoe lava created tubes and caves adaptable to human use as burial sites, refuges, and wartime fortifications (Burtchard and Moblo 1994).

Extant data and verification survey. In addition to modern lava coverage, speculative housing and large-scale agriculture have altered a substantial amount of land in the GRSs. A verification survey was conducted to inventory as many samples of the oldest flows and isolates, or kipuka, as possible. A description of each subzone, which follows, includes a summary of human settlement and land use, an assessment of the potential archaeological record, and a listing of extant survey results. All sites identified as part of this verification survey should be considered potentially significant, pending more detailed examination (Sweeney and Burtchard 1995).

Kapoho Subzone. Coastal settlement occurred perhaps as early as ca. 300-600 A.D. along the windward coast of Puna District, but is likely to be represented only to a distance of about $0.8 \mathrm{~km}$ ( $0.5 \mathrm{mile})$ inland at the easternmost tip of the Kapoho Subzone. Trails linked coastal settlements to agricultural plots farther inland. The eastern portion of the subzone was the first to be used intensively for subsistence crops, followed by the more distant western portion. A network of upslope/downslope trails developed during middle to late prehistoric times to link coastal settlements with these agricultural areas; land use in the western portion of the subzone was associated with short-term exploitation of forest floral and faunal resources and cross-country travel between Hilo Bay and points west. Structures reflect a wide range of residential, ceremonial, and agricultural functions with travel way-stations, emergency crop areas, and refuge and ceremonial places at the farthest west extreme (Burtchard and Moblo 1994).

Recent volcanic activity has been extensive in the Kapoho Subzone; in 1960, a flow covered most of the eastern end. Impacts from industrial and agricultural development have also been considerable. Sugar and papaya plantations and other farming operations cover $60-70 \%$ of the total area. Strip mining of red and black lava and geothermal development cover a large part of the subzone's west-central portion. Since the Kapoho subzone probably received the most intensive prehistoric use, it is unfortunate from an archaeological perspective that recent flows 
and development have substantially altered over $90 \%$ of the natural landforms. "It is unlikely that ground put to either agricultural or mining/geothermal uses will preserve a substantial portion of the previous archaeological record. This probability makes it particularly important that remnant, intact land surfaces be surveyed thoroughly" (Burtchard and Moblo 1994). Important remnants in Kapoho Subzone consist of small, untouched areas such as volcanic crater floors and older volcanic cones in the extreme northeast comer of Kapoho Subzone, and a few areas in which the oldest sediments have escaped exposure to recent volcanic activity. The highest density of agricultural features can be expected at elevations of up to $60 \mathrm{~m}(200 \mathrm{ft})$, and a moderate density at 60-210 m (200-700 ft) (Burtchard and Moblo 1994).

The greatest density and variety of prehistoric surface features can be expected in this subzone. Extant sites on the windward coastal margin of Kapoho Subzone include lava tubes and cave springs, petroglyphs, village remains, and heiau (temples or related sites of worship). Farther inland, sites include a holua slide (a slope used for a sled course) and agricultural complexes. A survey of crater floors and intact ground on the oldest flows revealed additional remains of agricultural areas (Burtchard and Moblo 1994). The survey also generated new data on two sites previously recorded during a much earlier survey, a heiau with walled platform and multiple terraces and a nearby slab-lined cyst possibly used as a burial crypt. Because it contains a large number of plants of known economic importance to prehistoric Hawaiians, an area of Pu'u lena Crater is identified as a "Hawaiian plant cultigen association" (Sweeney and Burtchard 1995). Skeletal remains were found in a lava tube formed by a 1790 flow through Kapoho. The cave entrance is easily accessible to the public, and the remains have been disturbed. Surprisingly, given that a relatively high density of prehistoric remains was anticipated near the coasts, cultural remains were not found in a kipuka at Kipu Point. The presence of coarse sediments suggests that the kipuka could be younger than was previously thought. However, the site might also have been poorly suited to prehistoric use for some reason not yet known (Sweeney and Burtchard 1995).

Kamaili Subzone. This subzone was the site of upland agricultural development on terrain at elevations of up to $450 \mathrm{~m}$ (1500 ft), 8.1 to $9.7 \mathrm{~km}$ (5 to 6 miles) from the coastline. As the drier leeward coastline south and west of Kaphoho began to be settled, residents planted dryland crops on inland slopes in the southern halves of the Kamaili and Kilauea Subzones at an elevation of $335 \mathrm{~m}$ (1100 ft) to the lower margin of the East Rift Zone. The southern rift slope area was probably farmed less intensively and at a later period than Kapoho, perhaps when the sweet potato was introduced. Archaeologists theorize that this important introduction occurred late in the prehistoric period (Burtchard and Moblo 1994; Abbott 1992). Since expansion into this area was later and less intense, the density of archaeological sites could be expected to be moderate, and lower than in the Kapoho Subzone. Scattered features could include ceremonial sites, huts and garden plots, remnants of groves, dryland taro and banana cultivation, and agricultural terraces and walls-particularly in historically documented planting areas and land grants in southeast Kilauea and Kamaili Subzones (McEldowney 1979). Lava tubes in pahaohoe flows could be expected to contain elaborate refuge and burial features (see the discussion of lava tubes). 
Post-1950 volcanic flows on the lower edge of the rift zone and sugar production, covering an extensive area in the northern portion of the subzone, have altered approximately $25-30 \%$ of the Kamaili Subzone. Roads, lots for speculative development, and several mining operations have also affected the southeast portion of the subzone. In unaltered areas, dense ohi'a forest with a subcanopy of native uluhe fern and exotic introductions impede field examination. Surveys should target kipuka and other unaltered remnants of the oldest sediments. Efforts should be made to relocate and trace trail routes and to identify and map lava tube systems in areas where the existing network of roads make field work possible (Burtchard and Moblo 1994).

Prior to the 1994 survey, the only site identified tentatively for the Kamaili Subzone in an area of recent lava flows was a portion of the Wilkes Trail of 1840 (The actual location of the trail has not been verified)(McEldowney 1994). The present verification survey identified five sites, two of which are prehistoric: a Hawaiian plant cultigen association located in a kipuka and a circular mound and step platform indicating a possible burial within a partially collapsed lava tube at the base of Lilewa Crater. The historic sites identified are a railroad bed associated with the Pahoa Lumber Company during the early 20th-century industrial development of Puna, a road bed coinciding with the location of the Upper Puna Road that linked plantations to Pahoa at that time, and a horizontal bunker with concrete entry and ventilator shafts excavated into the a'a spatter deposits along a volcanic crater's rim and reinforced by wooden beams. The structure was probably used for storage during World War II (Sweeney and Burtchard 1995).

Kilauea subzone. Located at an elevation of $450-750 \mathrm{~m}(1500-2500 \mathrm{ft})$, the central and westernmost portions of the Kilauea Subzone include the upper margins of guava forest and shrubs and the lower margins of lehua forest and uluhe fern that extend from $450-2100 \mathrm{~m}$ $(1500-7000 \mathrm{ft})$. Initially, this area was rarely used because of its distance from the coast. However, once population density and related demands on resources grew, Hawaiians more frequently used these forests for overland travel; for ceremonial practice or refuge; to collect wood, fiber and bird products; or to plant crops on a limited basis. These were short-term, low-intensity uses, and structures were probably limited to temporary huts and agricultural mounds (Burtchard and Moblo 1994).

Post-1950 lava flows covering much of the subzone's southwest portion represent the single largest impact on the available archaeological record. In comparison, recent exploratory drilling for geothermal development, logging and associated rail construction, and forest clearing and ranching in the southeast comer have had a relatively low impact. Overall, the impact of nature and human intrusion upon the archaeological record has been low, and theoretically $80-95 \%$ of the subzone is available for survey. However, much of this area is dominated by dense coverage consisting of ohi'a trees and uluhe fern. Surface signs of archaeological remains are difficult to recognize in heavy vegetation and rough terrain, and trails to and between coastal settlements are particularly difficult to recognize. Because they are visible in aerial photographs, lava tube cave openings once used as temporary shelters and refuges "may represent the most readily recognizable prehistoric features in the Upland Forest Zone" (Burtchard and Moblo 1994). Surveys have thus far been limited to required examinations of geothermal well pads and road 
corridors and to explorations of known lava tube systems. As in the Kamaili Subzone, recommended surveys should cover remnants of the oldest sediments and kipuka and should incorporate extensive mapping of lava tubes and efforts to relocate and trace routes.

Prior to the 1994 archaeological survey, no prehistoric features had been identified in the Kilauea Subzone other than caves and trails. However, historical records indicate the presence of widely scattered hunting shelters and waysides adjacent to the trail leading to Hilo. Extant archaeological sites consist of the Wilkes trail of 1840 (unverified) and the Kaimu trail that passes through lower Kilauea and Kamaili Subzones, a railroad spur and berm in upper Kilauea, rock cairns (possible burial features), lava tube caves in tubes known to extend into southern and northern portions of the Kilauea Subzone, and a northern unnamed trail. An examination of seven sample survey areas revealed three sites: seven circular mounds and a terrace platform with possible burial function (previously identified), another lava tube cave with multiple skylight openings that may contain early historic and/or burial remains (entrance was not accessible), and a Hawaiian plant cultigen association adjacent to a small crater notable for its absence of invasive plants (Sweeney and Burtchard 1995).

Lava tubes A number of extensive lava tube cave systems have been reported for the general East Rift area, and many of these can be presumed to contain early historic features and burial remains. The results of examining the Malama Burial Cave in Kapoho and the Lilewa Lava Tube in Kamaili for this survey were consistent with this assessment. While access to the Upper Kaimu Cave in Kilauea was not feasible, subsurface investigations should be pursued (Sweeney and Burtchard 1995). In 1991, McEldowney and Stone explored portions of three tube systems and tentatively identified other tubes in the same flow that passed through the northern half of the Kilauea subzone. Based on linear sinkhole alignments in aerial photographs, archaeologists have suggested that "at least two of these tubes enter the subzone" (Burtchard and Moblo 1994) (see also McEldowney and Stone 1991). The tubes explored thus far contain extensive burials, refuge or residential remains, and fortifications; similar archaeological remains could be anticipated for the northern Kilauea subzone. "Because of the exceptional preservation that caves often afford cultural remains, they retain a wealth of archaeological information that can be dated with relatively high accuracy. Their presence in the study area provided an unusual opportunity to investigate a variety of cultural issues" (Burtchard and Moblo 1994).

Traditional cultural sites. Hawaiians are hesitant to identify places in the Puna District that they consider to be legendary or sacred sites (wahi pana). However, anchialine ponds and spiritually significant steam pools (currently unidentified) in the Kapoho Subzone could qualify as traditional cultural sites because of their significance to contemporary Hawaiians (Matsuoka et al. 1995). Particularly significant sites of this type may be eligible for listing in the NRHP as traditional cultural properties. The larger, mythical landscape of Kilauea associated with the goddess Pele could also be considered a cultural landscape (as defined in the introduction to Sect. 4.6.2) (State of Hawaii 1993).

South and North Hilo. The study area between the GRSs and the Saddle Road includes areas of upland agriculture, lower forest, and rain forest, and passes through what is now state 
reserve land. During historic native settlement, scattered huts, garden plots, and small groves of trees predominated at elevations of up to $460 \mathrm{~m}(1,500 \mathrm{ft})$. Sites associated with sugar cultivation, rock and lumber industries, and the expansion of the local railroad system during the 19th and 20th centuries may also exist at lower elevations (see Sect. 3.3). Agricultural features and ditches are most likely to exist in such peripheral areas as abandoned fields near areas of present cultivation and at the lower edges of forests.

Hawaiians used the lower rain forest at elevations of $460-760 \mathrm{~m}(1500-2500 \mathrm{ft})$ to gather wood, feathers, fiber products, and supplemental foods. Historic accounts suggest that temporary camps, small shrines, and trails were likely in this area, but the probability of finding structural evidence is low because of the dense character of ground cover. Evidence of introduced cultigens such as banana, taro, ti, and yams still remains, and areas containing these cultigens indicate a higher probability of archaeological sites. Although many of the same resources occur in the rain forest at elevations of 760 to $1680 \mathrm{~m}(2500-5500 \mathrm{ft}$ ), factors like dense vegetation, the preferences of valued plant species for habitats at lower elevations, increased distance from settlements, the temporary nature of human activity here, and the discomforts associated with increased rainfall and cold at higher elevations decrease the possibility that tangible remains of prehistoric land use can be found. Site probabilities are highest near trails (McEldowney 1979).

Saddle area. The study area includes a subalpine zone in the saddle between Mauna Kea and Mauna Loa in Hamakua District at an elevation as high as $2300 \mathrm{~m}$ (6500 ft) above sea level before dropping to $760 \mathrm{~m}(2500 \mathrm{ft})$ in the vicinity of grasslands near Waimea. Historic accounts document four early trails in the vicinity of the present Waikoloa Ponds: the Hilo-Pu'u 'O'o trail, the Pu'u 'O'o trail north to Waimea, the Pu'u O'o trail south to Volcano, and the Saddle route between Mauna Kea and Mauna Loa (see Fig. 4). The saddle between Mauna Kea and Mauna Loa at elevations of 1600 to $2100 \mathrm{~m}$ ( 5200 to $7000 \mathrm{ft}$ ) was a crossroads for communication between leeward and windward sides of the island. The types of sites that may occur include camp sites and caves used for shelter while gathering, hunting, or traveling. However, substantial portions of the trails follow historic lava flows that have obliterated evidence of earlier historic and prehistoric routes, making systematic identification of sites difficult (McEldowney 1979). Located near the study area traces of the Pu'u O'o Volcano Trail, a lithic scatter containing basalt flakes and adze preforms, and a lava tube shelter cave, probably used during the later prehistoric era by travelers as a rest stop or as a camp from which to hunt birds and procure food (Barrera 1987; Welch 1991). A recent survey for a transmission route along the Saddle Road identified five single-site features and one site complex (Kalima and Rosendahl 1991). For an additional overview of archaeological resources in this region, extending to Waimea, see Hunt (1992).

Perhaps the most significant site in the area is the massive Mauna Ke'a adz quarry, a primitive quarry located at elevations of $2700-3800 \mathrm{~m}(9000-12,400 \mathrm{ft})$ and used by prehistoric Hawaiians to obtain fine quality basalt for stone implements (see Table 4 and Fig. 4). The complex, a National Historic Landmark listed in the NRHP, consists of workshops, shelters, shrines, basalt flakes, adze preforms, and plant and animal remains (Kirch 1985). Burials and debris from pits and workshops could be located at lower elevations included in the study area 
Table 4. National Register and National Landmark sites and districts

\begin{tabular}{|c|c|c|c|}
\hline Island & Site/district: & Location & Designation \\
\hline \multirow[t]{2}{*}{ Hawaii } & $\begin{array}{l}\text { Bobcat Trail Habitation Cave } \\
\text { Brown, Francis E.Ii House } \\
\text { Imiola Church } \\
\text { Kilauea Crater } \\
\text { Lapakahi Complex } \\
\text { Mauna Kea Adz Quarry (largest primitive } \\
\text { quarry in the world; prehistoric) }\end{array}$ & $\begin{array}{l}\text { Pohakuluoa } \\
\text { Kamuela } \\
\text { Waimea } \\
\text { Hilo } \\
\text { Mahukona } \\
\text { Hilo }\end{array}$ & $\begin{array}{l}\text { NR } \\
\text { NR } \\
\text { NR } \\
\text { NR } \\
\text { NR } \\
\text { NR/NL }\end{array}$ \\
\hline & $\begin{array}{l}\text { Pu'ukohola Heiau Nat'l Historic Site } \\
\text { (impressive temple associated with } \\
\text { Kamehameha the Great and his rise to power } \\
\text { in 1790-91) }\end{array}$ & Kawaihae & NRNL \\
\hline \multirow[t]{2}{*}{ Maui } & $\begin{array}{l}\text { Lahaina Historic District (former capital of } \\
\text { Maui and center of merchantry and missionary } \\
\text { activities; mid-19th century) }\end{array}$ & Lahaina & NRNL \\
\hline & Wo Hing Society Building & Lahaina & $\mathbf{N R}$ \\
\hline \multirow[t]{2}{*}{ Lana'i } & $\begin{array}{l}\text { Kaunolu Village Site (well-preserved ruins of } \\
\text { a fishing village deserted in 1880; date } \\
\text { unknown) }\end{array}$ & Lanai City & NRNL \\
\hline & Pu'upehe Platform & Lana'i & NR \\
\hline Molokai & $\begin{array}{l}\text { Multiple archaeological sites } \\
\text { Kamehameha V Wall } \\
\text { Southwest Moloka'i } \\
\quad \text { Archaeological District } \\
\text { Hokukano-Ualapue Complex (complex } \\
\text { includes } 6 \text { temples and } 2 \text { fishponds; dates } \\
\text { unknown) }\end{array}$ & $\begin{array}{l}\text { Kawela } \\
\text { Kawela } \\
\text { Maunaloa } \\
\text { Ualapue }\end{array}$ & $\begin{array}{l}\text { NR } \\
\text { NR } \\
\text { NR } \\
\text { NRNL }\end{array}$ \\
\hline Oahu & $\begin{array}{l}\text { Bellows Field Archacological District } \\
\text { Waimanalo Ditch System }\end{array}$ & $\begin{array}{l}\text { Waimanalo } \\
\text { Waimanalo }\end{array}$ & $\begin{array}{l}\text { NR } \\
\text { NR }\end{array}$ \\
\hline
\end{tabular}

-Sites listed for the island of Hawaii and Maui are located (along with State Register sites) on maps; see Figs. 4, 5 , and 6. WRR = National Register of Historic Places; NL = National Landmark.

Sources: NPS 1993; NPS 1987. 
(McEldowney 1993). The saddle area contains additional structural evidence of historic sites, including trails, ranch buildings, and walls. (See Sect. 3.3 for further discussion of historic sites.)

South Kohala-Waimea and Kawaihae. Further north, the saddle widens into a plateau between Mauna Kea and the Kohala Mountains containing Waimea and Lalamilo, two areas of substantial agricultural development during the late prehistoric period. Realignment of a highway connecting Waimea and Kawaihae facilitated the study of a transect from the arid coast to

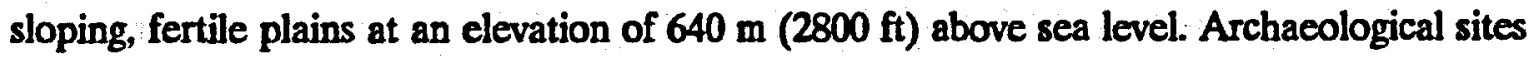
range from residential and burial sites at low elevation to inland agricultural complexes at the highest elevation. Scattered residential features and burial sites are found at elevations of up to $150 \mathrm{~m}$ (500 ft). Dominant archaeological features of the inland Waimea field system include parallel stone field boundaries, terraced agricultural fields, irrigation channels, work areas, and field shelters (Clark and Kirch 1983). Two important routes parallel this settlement pattern. The Waikoloa Stream trail connects the coastal area of Kawaihae with the uplands of Waimea. The old Kawaihae-Waimea Road, built with convict labor, illustrates fine stone work from the historic era (see Fig. 5; Townscape, Inc. 1992).

Being hot and dry, Kawaihae was not conducive to agricultural development but was an important sheltered natural harbor and settlement site. Kawaihae was one of several residences of Kamehameha I, a native chief on the island of Hawaii, who conquered chiefdoms throughout the Hawaiian islands during the late 18th century. His luakini (war temple), called Pu'ukohola, is now a National Historic Landmark under management of the NPS (see Table 4 and Fig. 5). This park site also includes the stone foundations of the house of John Young, an English seaman who served as advisor to Kamehameha (Rosendahl and Carter 1988). By the 19th century, Kawaihae was a strategic calling point for many early European traders. Just north of Kawaihae, the coastal area contains a dense clustering of sites south of Honokoa Gulch that extends inland. Permanent habitation sites are evident, and a belt of several hundred burials exists inland (mauka) from the Akoni Pule Highway. Temporary shelters in the area may have been associated with the construction of Puukohola heiau (Townscape, Inc. 1992). A recent survey conducted for the DHHL for use in the Kawaihae Ten-Year master Plan located 147 previously unidentified features in this vicinity (Hammatt and Shideler 1991).

Leeward North Kohala-Mahukona Bay. Dryland agricultural field systems capable of sustaining dense populations emerged here, and settlements exceeded those in South Kohala (with the exception of Kawaihae and Waimea). According to existing archaeological surveys of this region, permanent housing and heaiu were scattered along the shore in dispersed "core" communities with subsequent settlement occurring in intervening areas (Cordy and Kaschko 1980; Townscape, Inc. 1992). Along this rugged coastline, habitation clusters appear to have been associated with canoe access (Tuggle and Griffin 1973). Nearly all the sites fall into a relatively narrow zone paralleling the coast, between sea level and an elevation of $50 \mathrm{~m}(165 \mathrm{ft})$. At Lapakahi State Historic Park and in the immediate upland area, there exist the remains of an extensive coastal settlement and a dryland field system including walls and shelters, habitation complexes, water catchment features, rock mounds, and trails. Evidence of trails, fishponds, 


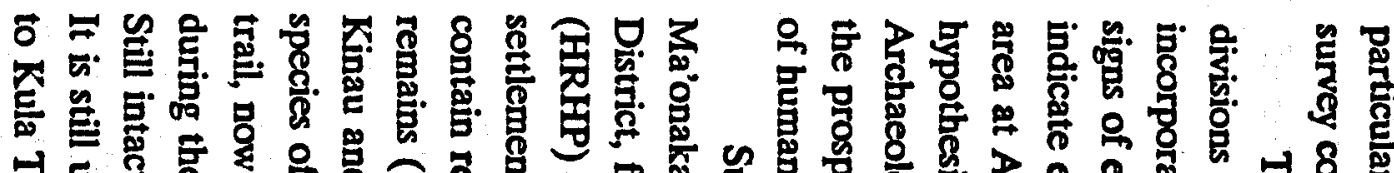

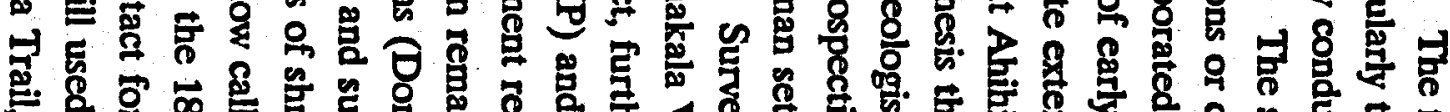

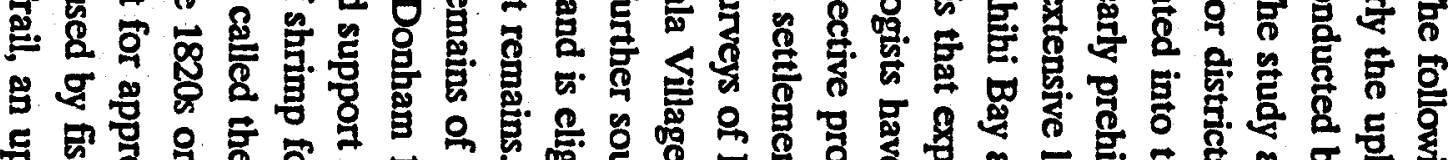

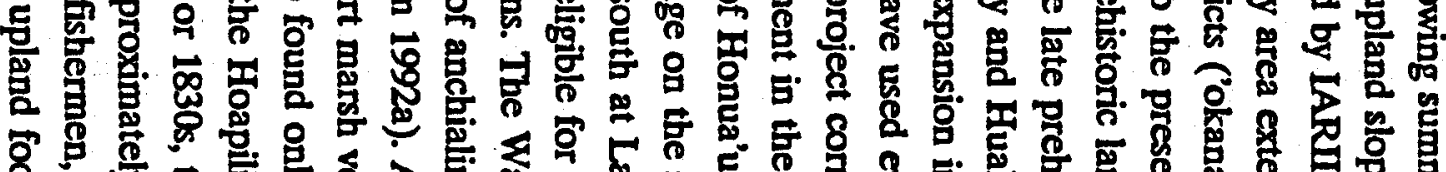

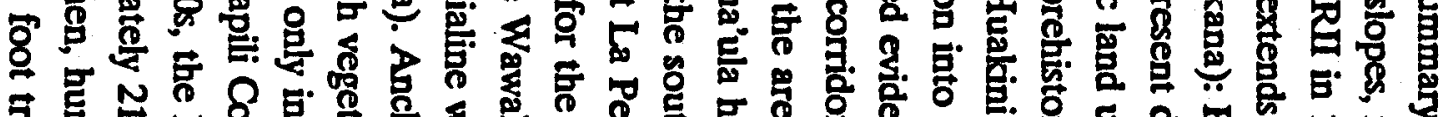

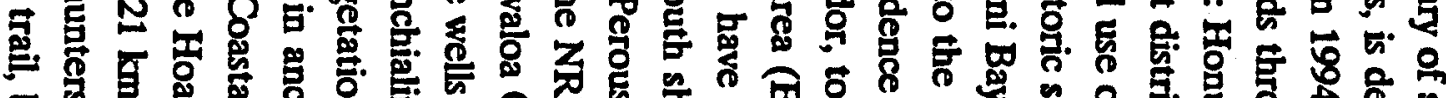
马

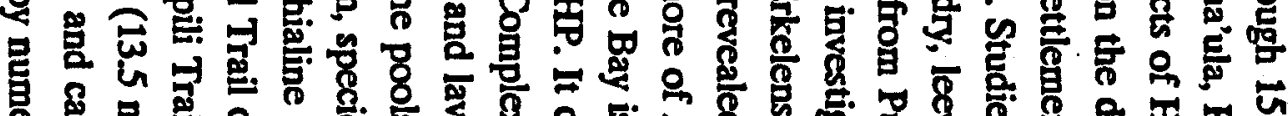

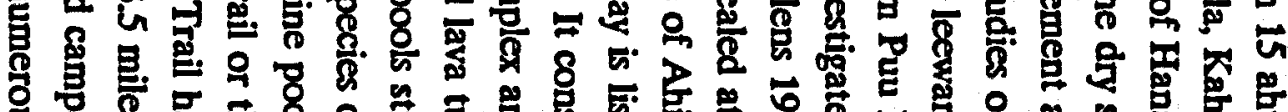

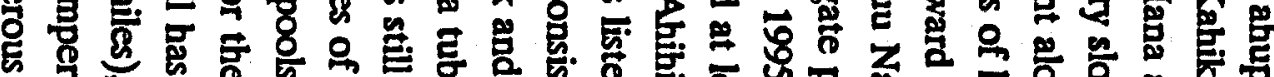

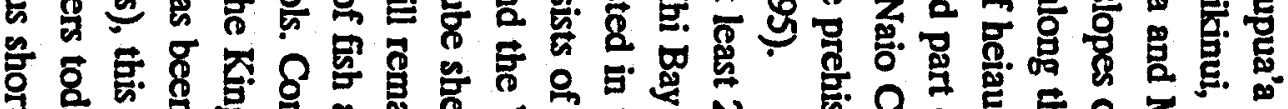

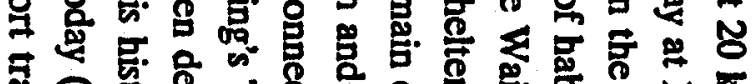

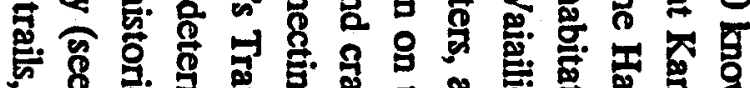

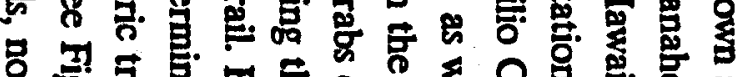

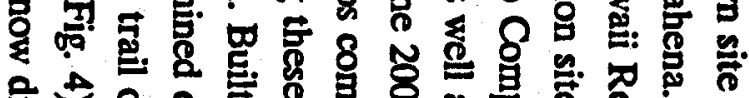

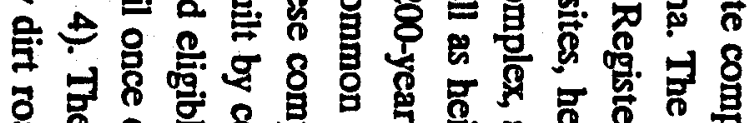

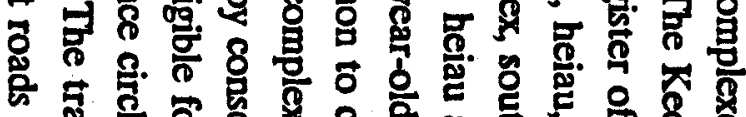
突

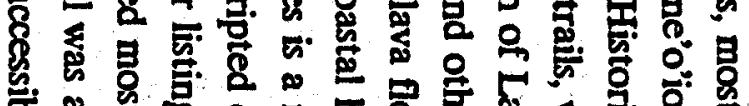

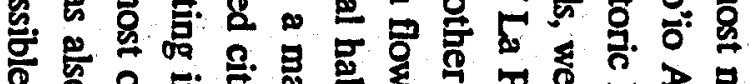

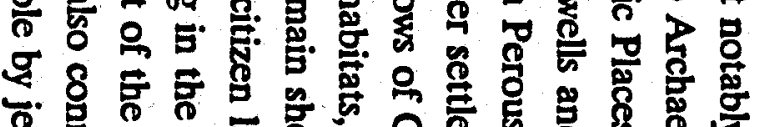

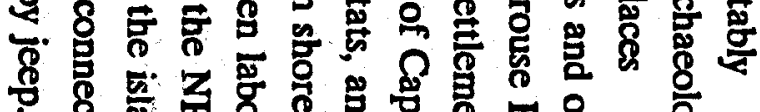

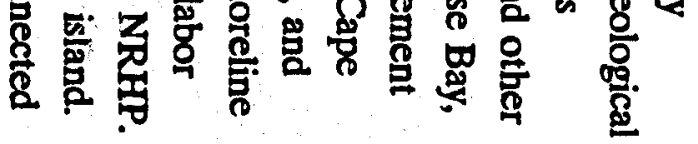

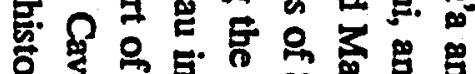
है. ๙

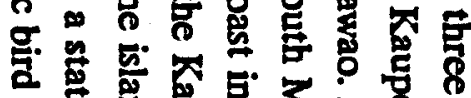

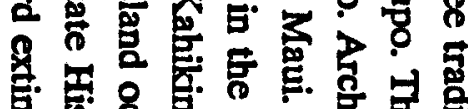

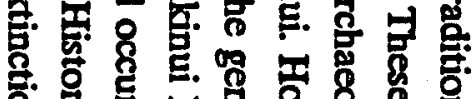

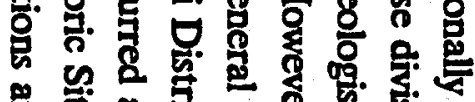

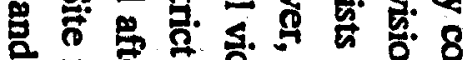

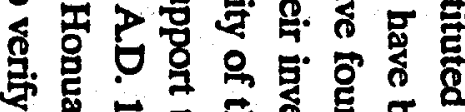

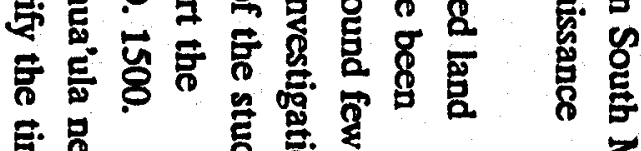

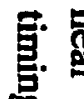

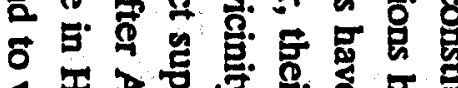

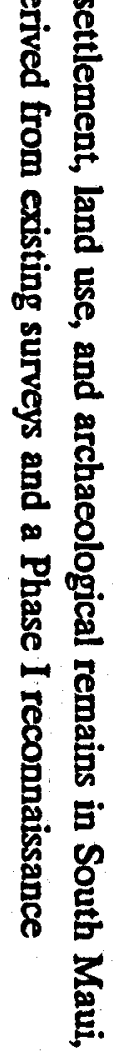

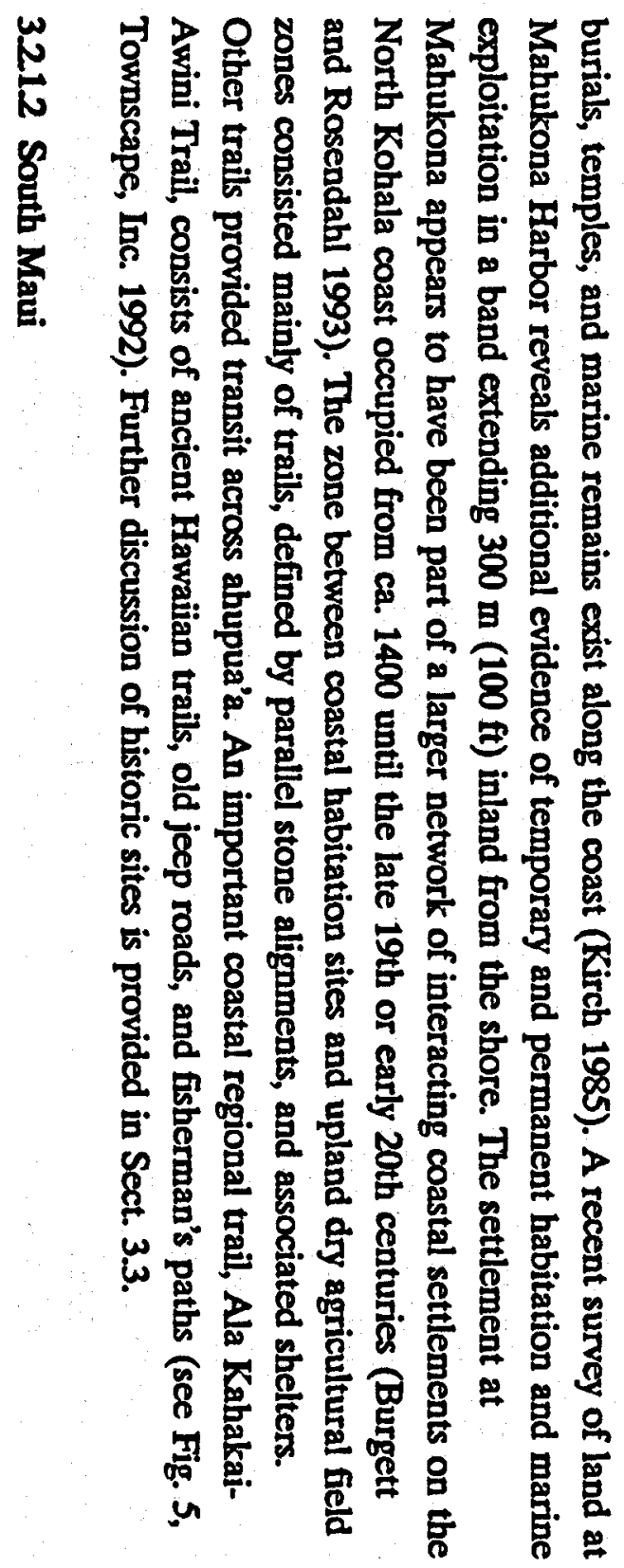


Piilani Highway (Route 31), known in the late 19th century as Hana Road, covers essentially the same route as the Kula Trail. The study area includes a section of the King's Trail at the east end and sections of the Hana Road in Kahikinui (Erkelens 1995).

Heiau sites are particularly prevalent in South Maui. In 1929, Winslow Walker recorded 15 heiau in Honua'ula. Several, located along the coast or near Kanaio Village, are in the general vicinity of the study area. Another 16 heiau, most of them identified by Walker, have also been documented for Kahikinui. Eight of these are located along or near the coast, but four are located in the upland area of Kipapa Archaeological District. It is likely that additional upland heaiu sites are present at this elevation, 439-686 m (1440-2250 ft) (Donham 1992b).

The Kipapa District, listed in the HRHP, extends from the coast in the vicinity of Kipapa and Naka'aha to an elevation of $790 \mathrm{~m}$ (2600 ft). Approximately 712 features have been designated and enumerated, including enclosures and walls, religious structures, and possible burials. The inventory includes two historic sites, Kahikinui House (listed in the HRHP) and the Santa Ynez Church (Donham 1992b).

Sites recorded in the immediate area of Lualailua hills include Lualailua Cave, a temporary shelter located just south of the Kula Trail, and heaiu sites (HRHP, Sites 182 and 186), located along the northeastern and northwestern edges of Lualailua Hills [about $730 \mathrm{~m}$ (2400 ft) elevation] (Donham 1992b).

Additional coastal complexes in Kahikihui are outside the study area but indicate the magnitude of resources encountered along the coast of South Maui. Surveyed village complexes include: Hanamauuloa, Waiailio, and Kalae o Kapulou and Nakaohu in Kipapa District. Known complexes at Kahawaihapapa and Kamoamoa have yet to be surveyed (Donham 1992b). Overall, there are nearly 600 features at 22 different complexes in a cultural resources management area consisting of two-thirds of Kahikinui District. "In Honua'ula and Kahikinui, sites can be expected to occur in any area that has not been disturbed." (Donham 1992a).

East of Huakini Bay at Nu'u in Kaupo is Nu'u Landing and Pond. Nu'u Landing was a traditional canoe landing site, later used for unloading cattle and shipping supplies. Today, it is still the most important landing site along that part of the Maui coast; people traveling by canoe or kayak and fishermen launch their craft there (Matsuoka et al. 1995). Additional archaeological sites and historic structures are located east of Nu'u in Kaupo. These include Lo'alo'a heiau, Hale o Kane heaiu, Popoiw Heiau, and Huialoha Church. The NPS proposes to add a large area of Kaupo, including all these sites, to Haleakala National Park.

At the time of European contact in the late 1700s, the upland slopes of Maui were used primarily for traditional subsistence and cultivation of dryland crops like sweet potatoes. Since the 1840 s, most of the area has been grazed by cattle on large expanses of ranch land owned by Ulupalakua, Kahikinui, Haleakala, and Kaupo Ranches. Kanaio Homesteads and Kahikinui (and possibly a third unidentified location) served as major loci of upland settlement during the 19th century. Today, most residents live at Kanaio in the vicinity of Kanaio Church, established in 1825 by Protestant missionaries (Erkelens 1995; Matsuoka et al. 1995). 
Survey results. There has been little prior archaeological investigation of upland South Maui, with the exception of work accomplished in the Kipapa District. "Although earlier archaeological investigations provided an indication of the range of sites that exist in the area, [this] survey[supplies] the first systematically gathered sample of the historic resources that exist in Southeast Maui" (Erkelens 1995). The 1994 survey focused on a 43-m (140-ft)-wide, 27-km (17mile) crosscut of the upland slope. The survey consisted of a pedestrian survey of $15.3 \mathrm{~km}$ (9.5 miles) of this sample corridor. Private owners either ignored requests or denied access to the remaining $12.2 \mathrm{~km}$ (7.5 miles) of the corridor passing through Ulupalakua Ranch and other land holdings in the Kahikinui District. An area of approximately 10 acres was examined at each of two sites located on the coast.

The results of this survey, considered along with those of previous surveys, indicate that "there are no areas in this region of southern Maui that are devoid of archaeological sites except where bulldozing of vegetation has occurred" (Erkelens 1995). Archaeologists recorded 233 surface archaeological features at $\mathbf{5 1}$ different site locations within the surveyed portions of the corridor. These features, examples of traditional Hawaiian dry stone masonry construction, consist of temporary shelters, habitation structures, platforms, probable animal pens, enclosures, terraced platforms (potential religious structures), modified rockshelters, lava tubes containing human burials, and 19th-century boundary walls and roadways. In addition, flaked stone tools and shellfish food remains were visible on the surface at some sites. Most of the sites appear to be Native Hawaiian sites dating to prehistoric or early historic periods. A few sites are clearly historic and post-date the advent of ranching in the 1840 s. Among the most notable findings were lava tube openings containing burial remains and the bones of extinct birds. Numerous sites located in barren a'a lava fields at slope elevations considered unsuitable for agricultural development indicate that, contrary to previous speculations, settlement may have occurred at middle elevations below $427 \mathrm{~m}$ (1400 ft) (Erkelens 1995). All sites identified as part of this reconnaissance survey should be considered potentially significant, pending more detailed examination (Erkelens 1995).

Huakini Bay. No archaeological sites were discovered at this site on the east coast of leeward Maui. The presence of a boulder beach and a high-energy erosional and depositional environment in near-shore waters indicates that archaeological sites are not likely to exist, though subsurface sites are possible. Perusal of the shoreline from Huakini Bay to Pahihi Gulch [located approximately $800 \mathrm{~m}$ (2700 ft west)] revealed that shear vertical sea cliffs replace the boulder beach.

Huakini Bay to Manawainui Gulch. An examination of this area between the bay and the highway revealed 20 surface features in $\mathbf{1 0}$ sites. The sites consisted of temporary shelters, permanent habitations, and one terraced platform that local informants have treated as if it were a heiau or ko'a (a religious structure) by placing traditional Hawaiian offerings on the surface (Erkelens 1995). Much of this area shows evidence of mechanized clearing and contains temporary ranching shelters.

Manawainui to Kipapa. The 2-km (1.2-mile) section of grassland and occasional a'a lava from Mahamenui to Kipapa contained an abundance of sites -90 features distributed in 27 sites, 
including terraces, platforms, enclosures, lava tubes, and wall segments. Late 19th-century maps suggest that settlement could have occurred approximately $1 \mathrm{~km}(0.6$ miles) uphill from the present highway in this vicinity. This survey located an additional 30 features not formerly noted by Chapman in his survey of Kipapa, described above. Nakaaha ahupua'a, made up of open, rolling grassland, contained no evidence of archaeological sites, perhaps because of mechanized clearing. Nakaohu ahupua'a, consisting of rocky terrain and scrub brush contained multiple sites, including lava tubes.

Alena to Lualailua. This $2-\mathrm{km}(1.2$-mile) section of extremely rough terrain contained 43 features in 14 sites, including another lava tube. Despite the rugged topography, archaeologists found signs of permanent habitation sites. Terrace platforms similar to heaiu remains previously identified indicate that settlement at Kahikinui was much more extensive than has been previously documented.

Lualailua to Ahihi Bay. The survey did not cover this section because access for purposes of archaeological investigation was not granted (Erkelens 1995). However, ongoing research suggests that habitation was largely restricted to the coast and to an area between approximately 330 and $360 \mathrm{~m}$ (1100 and $1200 \mathrm{ft}$ ) elevation. The lack of sites in between is due to arid conditions and poor soils (Erkelens 1995).

Ahihi Bay. For a distance of approximately $1.6 \mathrm{~km}$ (1 mile) inland, this section is part of the state Ahihi-Kinau Natural Area Reserve. Between the road and the shoreline, archaeologists identified 22 features within the project corridor. These features constitute a previously unrecorded portion of the Mo'anakala Village Complex, a site listed on the HSHP. Because the nearshore underwater area of Ahihi Bay is subjected to occasional high storm surf, there is little probability of additional sites nearer the coast. Inland from the road at Ahihi, archaeologists located an additional 18 features at 10 sites. These sites included temporary shelters, ranch walls, and constructed trails leading across the a'a lava flow (Erkelens 1995).

Lava tubes. Lava tubes in South Maui provided shelter, storage, burial sites, and freshwater near the coast. Portions of the tubes examined in the study area appear not to have been fortified for warfare as they were in the Puna District of the island of Hawaii. Hawaiian informants indicate that a burial cave with remains runs underneath the highway in the vicinity of Kanaio (Matsuoka et al. 1995). The archaeological survey also identified lava tubes in Kahikinui Home Lands within the project corridor, the precise locations of which are withheld to preserve confidentiality. One of the tubes contains multiple human burials and the skeletal remains of what are presumed to be extinct birds that once inhabited the region (Erkelens 1995). Because construction along the road across a tube extending from the vicinity of the road toward the coast could have an impact on burials, a developer would need to initiate consultation with various agencies and Hawaiians as required in state law and under NAGPRA.

Traditional cultural sites. The canoe landing and nearby fishpond at Nu'u Landing are important traditional cultural sites in continuous use by generations of Hawaiians. Particularly significant sites of this type may be eligible for listing in the NRHP as traditional cultural properties. The Kahikinui District is similarly important as a location of sensitive archaeological 
resources and as a primary site for contemporary Hawaiian homesteading and efforts in cultural resource management (Matsuoka et al. 1995).

\subsection{1 .3 Oahu}

Windward Oahu attracted early Polynesian settlers with its nonintermittent (i.e., permanently flowing) streams, fertile soils and high rainfall, and basin areas well suited to cultivation. The Bellows Dune Site, a particularly significant early archaeological site located on the property of Bellows Air Force Station near Waimanalo Beach, dates to the 4th or 5th century AD., making it one of the earliest dated archaeological assemblages yet known in the Hawaiian Islands (Kirch 1985: 71). The Bellows Field Archaeological Area, listed in the NRHP in 1974, incorporates the Bellows Dune Site and two other dune sites located at Waimanalo Beach Recreation Area. More recent studies have identified 22 additional resources potentially eligible for listing in the NRHP, half of which lie outside the area previously designated. This complex of sites has national significance in areas of aboriginal prehistory and science (Biosystems Analysis 1993). Further research is necessary to determine whether prehistoric settlement was temporary or permanent and whether some remains are indicative of 18th-century settlement patterns (Athens 1988). In 1993, archaeologists generated a predictive model that characterized density of artifacts at Bellows Air Force Station and designated additional areas of potential archaeological sensitivity (Biosystems Analysis 1993)(see Fig. 7 and Table 4).

Waimanalo supported numerous taro farms until the mid 1800 s when landowners converted their holdings first to cattle ranching and then to sugar cane production until about 1940. The U.S. Air Force completed Bellows Air Field in 1938. While the Waimanalo area is nonpredominantly military, urban, and agricultural, other findings in the vicinity demonstrate that "archaeological sites are not always obliterated by urban development and that the absence of significant sites cannot be assumed based simply on present land-use" (Kirch 1985). Prehistoric archaeological sites have been identified in inland areas that were formerly marsh lands. Recent surveys for a golf course extension north of Waimanalo and an agricultural park west of Waimanalo revealed historic archaeological sites: a branch of the Waimanalo Sugar Company irrigation system (about 1900) and two taro terrace complexes eligible to be nominated for listing in the state and National Registers (Hammatt et al. 1992; Hammatt and Borthwick 1988).

\subsection{Other Areas}

The study area includes the southern portion of Molokai and West Maui. Generic descriptions of key cultural resources located on these two islands follow.

South Molokai. Molokai displays striking ecological contrasts similar to those of other Hawaiian islands: it is well-watered to the east and arid to the west, has a rockbound cliff shoreline on the north, and has broad reef flats and fishponds to the south. An impressive concentration of shore ponds enclosed by rock walls with sluice gates (loko kuapa) and fishtraps 


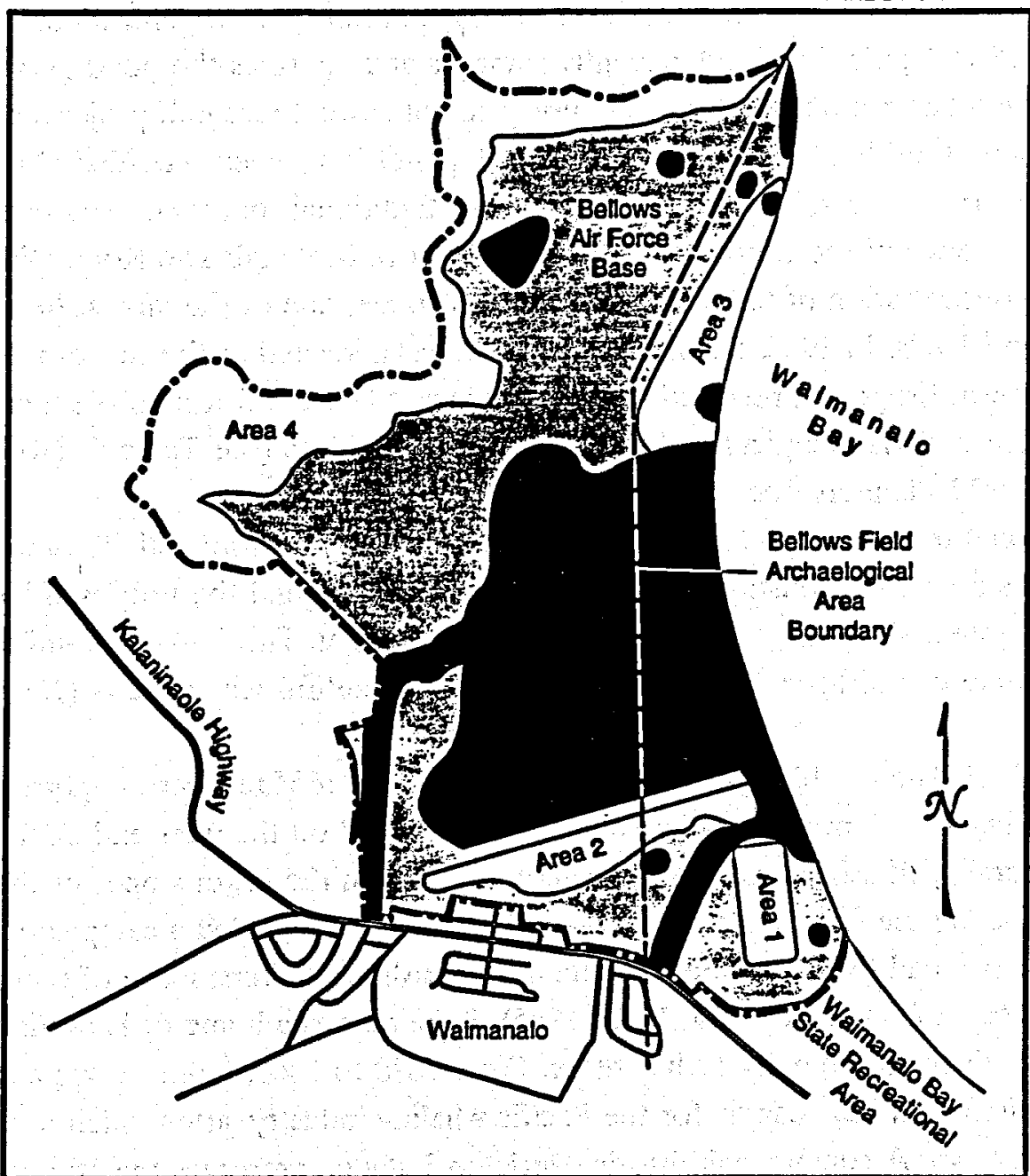

High Probability

Moderate Probability

Low Probability

Area 1- Missile site development

Area 2 - Negative archaeological findings

Area 3 - Negative archaeological findings Area 4 - Steep slopes

Native Hawalian

Archaeological Resources, Bellows Air Force Base,

Oahu

Source: Biosystems Anatysis, the.

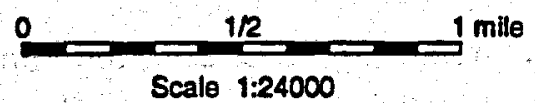

Fig. 7. Areas of potential archeological sensitivity on Oahu. 
of similar construction (loko 'umeiki) are still visible. A state task force on fishpond restoration has identified two demonstration fishponds on Molokai. A nonprofit organization, Hui o Kuapa, has rehabilitated Ualapu'e Pond and currently manages and operates the pond (Wyban 1992).

The island has not been extensively surveyed, but several research projects cover key sites distributed around the island. Remains of at least 50 ponds have been recorded along the south shore, some covering areas of 20 ha (50 acres). These traditional sources of wealth established the prehistoric importance of the southeastern Kona District of Molokai. The Kona District contains an impressive concentration of temples, including 'Tli'ili'opae, one of the largest heiau sites known in the Hawaiian islands. In 1982, a major survey of Kawela, located at the western edge of Molokai's region of fishponds, revealed another important late prehistoric settlement consisting of house sites, shrines, dryland agricultural features, and petroglyphs (see Table 4) (Kirch 1985; Wyban 1992; DHM Planners, Inc. 1989).

Traditional trails are also located in the southern region of Molokai. They include the Maunahui-Makakupaia Demonstration Trail near Alii Fishpond and the proposed Ke Ala Pupu i Molokai Trail System along the southwestern shore of Molokai. This 20-km (32-mile) segment of trail features numerous historic sites, rugged terrain, and beautiful scenic views ( $\mathrm{Na}$ Ala Hele 1991).

West Maui The foothills near Lahaina, on the island of Maui, were important sites of leeward taro irrigation. Contract surveys have been conducted on the west end of the island, but there is no general synthesis. Excavations during the 1970s on the lower slopes of the West Maui Mountains and along the coastline north and south of Lahaina revealed a camp site, evidence of a coastal settlement, small fishing shrines, and temporary fishing shelters; more of these sites are likely along the coast (Donham 1992a; Kirch 1985). Lahaina was a home of Hawaiian royalty from the 16th century through the early 19th century. From 1820 to 1860, Lahaina was a center for missionary activity and a key seaport for the Pacific whaling industry, after which it became a sugar plantation town. A commercial historic district in Lahaina preserves the atmosphere of a Hawaiian seaport and is a National Historic Landmark listed in the NRHP (see Table 4) (NPS 1987).

\subsection{OTHER HISTORIC RESOURCES}

Hawaii Archaeological sites in the Puna District dating from the historic period of European contact include remains of the Rycroft coffee plantation and mill at Pohoiki, another small coffee plantation located to the south, and the Lyman ranch near Kapoho Crater. Pioneer Robert Rycroft launched a boom in coffee production during the late 19th century; between 1896 and 1906, most of the 300 land grants made to speculators were for coffee. Other local industries included sugar production and rock and lumber milling operations. Remains of a logging railroad berm and railroad spurs are visible in the Kilauea subzone; additional remnants of these industries are likely to be found throughout the GRSs. A storage bunker from World War II is located in the Kamaili Subzone (Burtchard and Moblo 1994). 
Roads through the saddle area northwest of Hilo were scarce until the mid to late 19th century. Puu O'o Trail was established on a 1855 flow, and the Saddle Road was first identified as such in the 1920s. The historic ranching landscape includes vernacular outbuildings, walls built of lava to corral cattle and sheep, and other remains of the Humu'ula Sheep Station established about 1870 (Welch 1991). From volcanic slopes, the saddle area opens into the grass lands of Parker Ranch, one of the oldest ranches and once the largest Hereford ranch under individual ownership in the United States. John Palmer Parker, initially a cattle and produce supplier for Hawaiian royalty, leased land to start his own operation in 1837 and later amassed over 22,000 acres on the island of Hawaii. The original homestead has been replaced, but vernacular residences, out stations, stables, and sheds still stand (Brennan 1974). While modifications and contemporary intrusions exist, Parker Ranch still maintains sweeping open spaces, a familiar pattern of fence lines and outbuildings, and low-lying Paniolo (Hawaiian ranch-style) bungalows, set back from the road. Repetitive stands of eucalyptus, or swamp mahogany, planted as windbreaks, preserve an important element of the area's historic landscape (Reddick 1984).

Like the ranch, the town of Waimea has a mixed architectural fabric of original, modified, and new buildings. However, the town's dominant look is still vernacular Paniolo style. The best examples have gingerbread trim, patterned doors and window shutters, vertical siding, and distinctive Hawaiian roof forms with verandas and balustrades (Reddick 1984). Because of its overall visual and spatial coherence and continuity of use as a ranching area, parts of the Parker Ranch and Waimea may qualify as a rural historic landscape. A professional determination on the quality of Waimea's architectural and historic fabric is pending.

Maui. Other resources in the vicinity of the study area on Maui include ranch land used for grazing cattle since the 1840 s. The Kanaio Church, built in 1825 , is an example of vernacular architecture from 19th-c. settlement and Protestant missionary activity.

Oahu. Other resources in the vicinity of the study area on Oahu could include remnants of sugar cane plantations, such as those found north and west of Waimanalo (see Sect. 3.2.1).

\section{AESTHETIC RESOURCES}

Landscapes that reveal evidence of those forces which have shaped them-that make process visible-have always had great aesthetic appeal. The Grand Canyon and Yosemite Valley are well-known examples. They involve the user in immediate, visceral ways. In Hawaii, volcanic geomorphology, water and wind erosion, ash deposits, soil formation, microclimatic variations due to elevation, endemic and introduced plant communities and species, and the presence of ancient and modern humanity have combined to effect distinct landscapes of great beauty, mystery, value, and awesome, humbling power.

Native Hawaiians understand their land as a living being, a link to the presence of their gods, and as a vehicle through which forces seen and unseen pass (Ulrich 1993). This special relationship with the land is known as aloha aina, "love of the land." To understand the aesthetic 
appeal of landscapes to native Hawaiians, one can begin by examining the way their local place names combine observed physical characteristics of the place itself with symbolic references drawn from the location's underlying sense of energy. As an example of the revered sense of place from a Native Hawaiian's perspective, Ulrich (1993) cites a cliff along Waimea Canyon on Kauai. This cliff opens grandly to the valley and river beneath it, and is named Kaholuamano, meaning "the sledding place of the birds."

"In the case of the traditional Hawaiian, for example, almost every significant activity of life was fixed to a place. No genealogical chant was possible without the mention of personal geography; no myth could be conceived without reference to a place of some kind; no family could have any standing in the community unless it had a place; no place of any significance, even the smallest, went without a name and no history could have been made or preserved without reference, directly or indirectly, to a place" (Kanahele 1986).

"Hawaiian place names are, literally, poetry; their multilayered associations of topography, sexual innuendo, and mythic allusion dominate the chant and hula. Sayings also clustered around specific seas, rains, and winds attached to each island in the very old days; each place carried its own inimitable 'halo of delight or sorrow, specific personal, historical, and mythic associations. The act of naming itself . . . held great power. Speaking the names, chanting them, established cognitive control of the surrounding environment. Old-time Hawaiian storytellers peppered their tales with long recitals of place names both to authenticate the story as well as to allow the listener and teller alike to participate in the joy of hearing an accumulation of well-loved names" (Nelson 1992).

In 1993, the Hawaii State Legislature passed Act 156 acknowledging the importance of cultural landscapes, and created within the DLNR a task force to explore the designation of such lands in Hawaii and to recommend mechanisms to support their preservation. This task force has met, and its report is forthcoming. The DLNR comments that a major consideration in protecting or preserving a given landscape is not the necessity "to maintain all the components and attributes, but to accommodate changes without altering the general character of that landscape" (DLNR 1994). A central question in assessing the aesthetic impact of any development on Hawaiian landscapes, then, is forecasting whether the project or a project component alters the general character of given landscapes. Particularly noteworthy landscapes, as suggested by the DLNR, are agricultural, working landscapes such as the Parker ranchlands. The DLNR also suggests that the definition of a landscape "should be extended, as a continuum, from the land, across the shoreline, over the reef and out to the open sea."

Landscapes that are named and cherished by Native Hawaiians are also commonly revered by other residents and visitors alike. One aspect of the spectacular and everyday Hawaiian landscapes that is important to explore is the capacity of the landscapes in question to support an experience of getting away from daily concerns, a quick back-to-nature encounter.

Environments that restore, or reinvigorate, by permitting the visitor to sense escaping from the work-a-day world are highly valued for the aesthetic responses they induce. Environmental psychologists (Kaplan and Talbott 1983; Kaplan and Kaplan 1989) have investigated the capacity 
of different environments to support a "getting away from it all" experience. The struggle to pay attention in a cluttered and confusing environment is central to what we experience as mental fatigue. In restorative environments, people are able to rest their minds in a way that allows them to recover their effectiveness. Restorative environments do not depend on the directed, voluntary attention of the user; rather; viewers find themselves involuntarily enjoying themselves, as in looking at a litter of puppies or visiting a zoo (Petrich 1993).

Fascination can be assessed by the extent to which the attention paid to the environment is effortless. Fascinating subjects, those that can attract our attention without our even being conscious of the process, might include rushing water, animals, birds, waterfalls, wild flowers, caves, sunsets, or even insects in home gardens. Such elements hold the viewer's attention, but not in a riveted manner, allowing the mind to wander.

Biologist Edward O. Wilson (1984) asserts that people will walk into nature to explore, hunt, and garden if given the chance (c.f., Kaplan and Kaplan 1989): "They prefer entities that are complicated, growing, and sufficiently unpredictable to be interesting." The potential aesthetic impacts of any proposed developments on various Hawaiian landscapes can in part be evaluated by estimating the "amount" of fascinating features or opportunities available, assessing their relative allure for the various target users, assessing the coherence of the whole environs, assessing the comparison of the reality to anticipated expectations of target users, and assessing the absence of distractions or other intrusions (Petrich et al. 1989; Swihart and Petrich 1988).

\subsection{SOUTHEASTERN HAWAII}

Ohi'a forests create the dominant visual landscape in the southeastern portion of the Big Island. Of course, lava flows of various ages also leave a dominant visual image, and they are interspersed with the ohi'a forests as plant succession proceeds on the lava flows. Visually, the forests are two-tiered (Cuddihy 1989). The upper tier creates the higher canopy, composed of emergent trees and intermediate-stature trees. A lower, secondary canopy is formed with lowstature trees and tree ferns. An herbaceous plant layer dominates the forest floor. The main subcanopy, dominated by tree ferns, forms at about 6-9 m (20-30 ft) above the ground and is much more contiguous than the higher woody canopy above it. This subcanopy keeps sunlight from penetrating directly to the forest floor throughout most of the day. Raindrops are diffused by the fronds, resulting in less erosion of the forest floor. Humidity under the subcanopy is maintained at a higher level than in a more open or disturbed forest, resulting in a more constant environment for plant development on the forest floor.

In terms of the restorative potential of the native rainforest on the slopes of Kilauea, in those relatively scarce areas that are still undisturbed by pigs and/or other exogenous factors, one can experience an environment that facilitates escape from the everyday world and entrance into a world where contemplation of larger, longer-term issues is enhanced (Brower 1992). Where the rainforest has been disturbed by exogenous factors (roads, hunting trails, pigs, exotic vegetation), the secondary tree fern canopy is less complete, allowing more rain and sun in, thus changing the 
character of the underlying vegetation. The forest floor is broken by black, muddy trails from disturbance caused by feral pigs.

In addition to the various ages of lava flows, the wet ohi'a forest dominates the sideslopes of Kilauea. Matted-fern communities are generally found in poorly drained areas. The native, established tree fern/ohi'a forests are typically so dense that views out are feasible only from the periphery. Roads and paths afford short-distance views within the forest. Unvegetated lava flows account for about $10 \%$ of the land area of these sideslopes. Small kipukas, or remnant "islands" of older, open ohi'a forest that were sufficiently elevated to avoid being covered by later lava flows, occur throughout the area (Cuddihy 1989).

Views of the forest are of a low-growing, dense woodland. The younger forests growing on "recent" ( $<1000$ years) lava flows provide vivid and curious (to the outside visitor) examples of pioneer plant succession within this unstable landscape. Landscape features such as the kipukas provide visual interest and a window to the successional process. Process made visible is always of interest in design. The opportunity to see new land and landscapes created is the source of much of the visual fascination with the plant communities in the Kilauea sideslopes.

At higher elevations [greater than $300 \mathrm{~m}$ (1000 ft)] along the sideslopes, the wet ohi'a forest dominates the visual landscape. At the lower elevations, agricultural landscapes dominate. Sugar cane and papaya are the primary agricultural crops in the Puna District. Macadamia nut orchards and orchid nurseries also abound. Abandoned agricultural lands are now colonized largely by non-native plants. Very large alien mango and leguminous trees have created visually dramatic, majestic, high, closed-canopy alless with clear understories along some of the area's roads. This is particularly noticeable near Lava Tree State Monument (along Route 132) and along Pahoa-Pohoiki Road. The chief significance of the vegetation and views in the area is of the residential, natural, and agricultural character of most of the landscapes.

\subsection{POTENTIAL DEVELOPMENT CORRIDOR BETWEEN HILO AND THE NORTH KOHALA DISTRICT}

The visual quality of the dominant corridor connecting the east and west sides of the Big Island is characterized by broad skies, extensive horizons, and distant views of mountain tops, ridge lines, and tropical coasts. Open, relatively treeless ranchlands, grasslands, and lava fields predominate. Because of the scale of Mauna Loa and Mauna Kea and the dearth of rainfall, valleys and ridges on the leeward slopes are few, with the topography descending to the coasts as long, gentle slopes. Such an expansive landscape sweeps from mountain tops to coastlines and back. Numerous distinctive views of the ocean and of the mountains exist; each general area has its own aesthetic sensitivities. 


\subsection{Saddle Road Area}

The eastern section of the Saddle Road (Fig. 2) leading up to the top of the saddle between Mauna Loa and Mauna Kea is heavily wooded with ohi'a and fern forests. Views across the eastern slopes of Mauna Kea offer sweeping landscapes of the lush rain forest and agricultural areas north of Hilo. These windward areas have the highest rainfall on the island, and, correspondingly, on clear days offer a dramatic assessment of their vegetative density. Observers can scan to the ranchlands higher upslope and then to the heights of Mauna Kea on such days, contrasting the arid nature of the summit with the lushness of the windward slopes. The expansive grazing lands appear as green patches against the more mottled browns of the barren, arid landscapes near the higher elevations of Mauna Kea. The sideslopes of Mauna Loa are dominantly lava flows intermixed with very sparse shrubland.

From about the 900-m (3000-ft) elevation to the top of the Saddle Road area [1800 m (6000 ft)], the landscape becomes truly surreal (to the outside visitor) with cinder cones and barren lava flows intermixed with ranchlands, all dwarfed by the peaks of the two dominant volcanoes. Rock walls built by hand labor since recent lava flows add, for the outside visitor, an unusual cultural feature to the landscape. That these were built to enclose sheep while they "grazed" in what appear to be barren lava fields is difficult for a visitor to grasp, adding to outsiders' fascination with the whole environment. The area has $69-\mathrm{kV}$ and $136-\mathrm{kV}$ power lines running along the roadside to power the astronomical laboratories on the summit of Mauna Kea and to provide power to the north leeward side of the island.

Along the western, more leeward portions of the Saddle Road, the landscape becomes

even more barren, rocky, and dry. The Pohakuloa Military Training Area íntroduces a more disturbed, more urbanized landscape, albeit still within weathered lava flows. The landscape becomes punctuated more by pu'us of diverse sizes, colors, stages of revegetation, and ages. The more weathered lava flows support grasses and small shrubs. Jeep trails along them are highly visible. Several utility lines are visible along the toe of the steeper slopes of Mauna Kea. Ranchlands are still visible in the distance. Views of the Pacific Ocean along the western horizon are first visible here. Moving westward, the road descends through grasslands into the stands of scattered eucalyptus that characterize the ranchlands above Waimea.

Outstanding views of the mountains, Mauna Kea sideslopes, and Hilo Bay to the east abound from the eastern side of the Saddle Road. Views to the volcano summits change as one ascends the road and gains clearer vantage points while the vegetation thins nearer the road crest. The Saddle Road drive is a unique, high-quality aesthetic experience. Viewing this and the Kilauea Crater, one can readily experience the grandeur and meaning of primordial landscapes. Human impacts are evident, but at a scale that causes no dissonance competitive with the expansiveness of the sky, horizon, mountain tops, lava fields, and distant coastlines. One truly can, in a matter of only a relatively few miles, see the meaning of windward and leeward sides of island ecosystems and of a spectrum of stages of vegetative succession. Again, the road affords another 
opportunity to have basic biological, geological, and evolutionary processes made visible, fundamental sources of fascination and of aesthetic appreciation.

\section{Waikii-Waimea Area}

For the purposes of aesthetic description, it is convenient to define the Waimea area as the grasslands and ranchlands below the Saddle Road and above the town of Waimea. Waikii, the Parker Ranch, and other smaller ranches that thrive on the middle slopes of Mauna Kea are typically a surprise to the new visitor to the island of Hawaii. Most do not expect the cool, rustic countryside in a tropical island. These lands have been planted in imported grasses selected for their adaptation to local soil and moisture conditions. The vast pastures are subdivided into paddocks delineated by fences, stone walls, and wind breaks. The presence of Gothic houses, stables, picket fences, and Victorian buildings in a landscape of green grasses, grazing cattle, rodeos, and horses creates a curious aesthetic blend. The views from here to the Kohala Mountains and downslope to the South Kohala and North Kona coasts are grand and spectacular.

A series of distinctive and dramatic views from regional highways in the area has been identified in a draft plan developed by the County of Hawaii (Townscape, Inc. 1992) as worthy of protection. Beginning with the area just above the junction of the Saddle Road and the Hawaii Belt Road (Route 190, or the Mamalahoa Highway), this plan identifies the view looking westward over "undulating pasturelands, impressive pu'us, and mature stands of trees. The chance sighting of wild birds such as pheasants, francolins, turkeys, and owls, adds considerable interest to the drive through this area. The elevations start changing quickly at this point giving spectacular views of nearby pu'us, Mauna Loa, the slopes of Mauna Kea, and the distant Hualalai. Fog and cloud patterns create different moods for the area especially in the early morning and late afternoons."

Just northward of this point is a good view of Pu'u Nahonaohae to the north and of distant pu'us in the Waimea area. From just north of where the Saddle Road joins the Mamalahoa Highway, the plan identifies views of the town of Waimea with the Kohala Mountains behind them as being "striking, especially during times of the day when clouds create ever changing patterns. From this area the distant coastlines are impressive views. Beautiful sunsets can be seen, as well as evening views, as the lights of the Waikoloa Village and the distant resorts turn on."

West of Waimea, along the Kawaihae Road (Route 19), the draft plan identifies the Waikoloa Stream as providing "a rare opportunity [for the leeward side of the island] of viewing a mountain stream. Although the stream's flow is intermittent, the streambed has features that are bold and dramatic. Good views of the slopes of the Kohala Mountains and the pu'us can be seen along this area of the Kawaihae Road. Looking south and makai [downslope, toward the sea] are distant views of Kawaihae Harbor, the Kohala coastline, and the distant mountains." A 69-kV transmission line parallels the Kawaihae Road. 
From the Kohala Mountain Road (Route 250), spectacular views abound. Mauna Kea, Mauna Loa, and Hualalai are prominently in view, as well as the coastal resort areas of Waikoloa, Mauna Lani, and Mauna Kea. The plan identifies as "equally spectacular" the sunset and evening views. Nearer to Waimea on the Kohala Mountain Road, the plan identifies the near-ground view of Pu'u Kawaiwai as "interesting as it sits on the edge of the steep mountainside. A unique cloud pattern can be seen in the area as clouds moving over the ridge are met by updrafts causing the clouds to spiral upward. The makai views along this stretch of highway are spectacular. Views are of the Waimea area in the foreground with Mauna Kea, Mauna Loa, and Hualalai mountains rising up above pasturelands in the distance. Good views can be seen of the pasturelands around and mauka [upslope] of the Hawaii Preparatory Academy."

In places the Waimea-Waikii area ranchlands represent archetypal human landscapes. As such, they offer highest-level aesthetic experiences. The specific views encountered among these ranchlands were culturally developed in the 19th Century by an Englishman -witness the Victorian buildings-and honor the aesthetic norms of that Romantic period. That is, these views-unusually-are both picturesque and sublime, with the latter predominating: the grand and spectacular views are clearly sublime. It is the views of the ranchlands enclosed by the eucalyptus stands and the sideslope topography of Mauna Kea that proffer the classically picturesque.

As a design framework, the picturesque has produced "manifestly beautiful, delightful, useful, environmentally sensitive, and life-enhancing" landscapes (Howett 1987). In a sense, portions of the Waikii and Parker ranches in this area are idyllic pastoral parks in the Romantic tradition of seeing nature as a series of "views" worthy of being made into a picture.

\subsection{North Kohala Area}

The study area in the North Kohala District is one of very dry, windy, near-desert rolling grasslands and tropical, rocky coasts. The main woody vegetation consists of drought-resistant kiawe and haole-koa trees. As one travels north on the highway, the landscape becomes increasingly humid, tropical, and lush. Old lava flows intersect the landscape down to the coast in several places. The Akoni Pule Highway (Route 270) provides outstanding views of Maui to the north, Mauna Kea to the east, Hulalai to the south, and the various pu'us along Kohala Mountain Ridge to the northeast.

The county's draft plan (Townscape, Inc. 1992) identifies the intermittent Waikoloa Stream as being "very scenic." This plan notes, "On occasion a dramatic show of rushing water can be seen coming out of a very dry appearing environment. Good views appear (where the Kawaihae Road intersects the Queen Kaahumanu Highway to the south and the Akoni Pule Highway to the north) of the Kaiwaihae Harbor and the Mauna Kea Beach Hotel areas. In the distance are good mauka views of Mauna Kea, Mauna Loa, and Hualalai." Farther north, from the Akoni Pule Highway are very close views of the rugged lava coastline. Even farther north, one has good views of the pu'us along the Kohala Mountain Road, as well as beautiful views of Maui. 
A 69-kV electrical transmission line parallels the Akoni Pule Highway from the Kawaihae Road intersection to the Kohala Ranch.

Ancient foot trails along the coast have been identified by the state of Hawaii's Division of Forestry and Wildife (see Sects. 2.1.2, 3.2.1.1, Table 2). The state has a program, Na Ala Hele, for the identification and protection of the state's trails and access system. In their Program Plan (DLNR 1991b), state officials discuss trails that the program (through a series of public involvement processes) has identified as having special aesthetic features or views in need of protection. It is proposed that the Ala Kahakai Trail, running from Kailua Bay to Kawaihae Bay be made ready for public access in the future.

The North Kona, South Kohala, and North Kohala lava flows are extensive and distinctive for their absence of vegetation and for their coloring and texture. It is their stark, barren character that comprises their visual beauty. With increased lava weathering and increased rainfall, the barren lava fields give way to pockets of shallow soil in which pioneer grasses have taken hold (Townscape, Inc. 1992). The unique visual character of these landscapes comes from the contrast of the weathering lava fields with the pale green to bleached silver colors of the grasses. The grasses are tall enough to blow in the near-constant winds, providing another aesthetically pleasing dimension. The landscapes of kiawe and grassland savanna along with the azure blues of the tropical shorelines along the Akoni Pule highway are regionally distinctive and of very high quality.

The county's draft plan (Townscape, Inc. 1992) emphasizes, "It should be recognized that the scenic nature of these arterial roads is a very important part of the region's landscape character and of the region's economy. County planners and engineers, as well as state agencies and private landowners and developers must therefore work together to ensure that these scenic qualities are preserved and enhanced, and that future development along these roadways has little or no adverse impacts." The plan recommends "no-build" corridors, 90-m (300-ft) wide, along both sides of the major scenic roadways in the region: Queen Kaahumanu Highway, Mamalahoa Highway, Waimea-Kawaihae Road, Akoni Pule Highway, and Kohala Mountain Road. The intent of these open corridors is to preserve the "view from the road." This view is considered critical in the plan because most of the residents and visitors perceive and appreciate the visual beauty of the regional landscape primarily from the arterial roads.

The coastline of the northwestern portion of the island of Hawaii is tropical but extremely rocky with large lava boulders. Good views of Maui exist from some locations, but generally the area has poor visual accessibility. The lava rock shoreline is rugged, with deep water offshore.

Traditional Hawaiian culture attaches an acute level of articulation and discrimination to the land-sea interface (Kanahele 1986). Native Hawaiians see this area as a finely differentiated continuum, reflecting the importance of the sea in their daily lives and the importance of place. "[Hawaiians] divided the ocean into many more places, beginning with the shoreline, then moving outward to the deep. Kamakau (1976), for example, wrote: 'The place on land where waves break and spread is the lihi kai or 'ae kai, edge of the sea. Where they wash over the land is called pahola, hohola, or palaha ('spread'), and the place where they break and spread toward land is 
called pu'eone or poina nalu or point kai ...' He continued at length, listing other places inshore, the tidal pool area, where shallow seas come in without rising (into breakers), the surf line, the reef area, and beyond. This is an astounding enumeration of place after place, all named and demarked according to function and relative position" (Kanahele 1986).

\subsection{SOUTHEASTERN MAUI}

\subsubsection{Huakini Bay}

The coastline at Huakini Bay (Fig. 3) is low-gradient with a high-energy pebble-to-boulder beach environment that undergoes constant erosional forces from the wind and waves. The Piiliani Highway (Route 31, a low-grade, poorly traveled road) comes quite close to the beach here. The Huakini Bay has little significance visually because of its remote location and average visual quality beach. The Kaupo Gap area, which is visually distinctive, is nearby, but is under consideration for protection by the NPS (Fake 1994).

\subsubsection{Pỉilani Highway}

The Piilani Highway follows a desolate and severely scarred area resulting from the $\mathbf{1 7 9 0}$ lava flow, Haleakala's last eruption. Because this is the leeward side of the island, there is little vegetation and little weathering of the lava. The road permits spectacular seaward views accented by frequent views of whales. Views of Haleakala are directly uphill and are limited because of the steep slopes. Several gulches are extremely interesting aesthetically because of their large scale and their metallic-gray lava coloration. (This gray coloration is traceable out into the water discharged from the gulch, and is visible out into the Alenuihaha Channel from several miles away. This evidence of the erosive forces of water is another example of process made visible, and has its own aesthetic interest and attraction.) The gulches enable the viewer to see erosive processes made visible in an alarming way. Huge boulders have obviously been displaced and carried downslope by runoff from torrential downpours, yet the gulches are typically dry. One connects viscerally and intellectually with the towering height and scale of Haleakala without really seeing any of the volcano. Observers are made acutely aware that they are on the side of an enormous mountain.

The Hoapili Coastal Trail (Fig. 6) has been proposed by the state as a trail to be made accessible to the public in the future (DLNR 1991b). Lava fields in various stages of revegetation enhance one's understanding of successional processes and provide extensive, expansive open views to the ocean and to the island of Hawaii. The western end of this Maui study area provides outstanding views of Kaho'olawe and particularly of Molokini Island, a popular snorkel and scuba diving area.

Visitors using boats to get to and from Molokini Island have extensive views eastward along the southeastern coast of Maui. Aircraft flying into Kahului from Honolulu have a similar 
flight path that allows viewers to look directly eastward down the corridor. These areas are as wild, desolate, and uninhabited as any on the lower elevations of the leeward side of the island.

\subsubsection{Ahihi Bay and Kanahena}

The coastline on the western end of the southern portion of Maui is scarred by the 1790 lava flow. The coast here is boulder-strewn, unstable, and rugged, with little visual distinctiveness except for the proximity of the views to Molokini Island. There is a nearshore underwater reef.

\section{REFERENCES}

Abbott, I. A 1992. La'au Hawai'i. Traditional Uses of Plants, Bernice Pauahi Bishop Museum Press, Honolulu.

Abbott, I. A, and Lamoureuz, C. 1991. A Survey of Hawaiian Medicinal Plants in the East Rift Zone of Kilauea Volcano, report prepared for True Geothermal Energy Company (available from the authors).

Advisory Council on Historic Preservation. 1990. Section 106 Participation by Indian Tribes and Other Native Americans, Washington, D.C.

Athens, J. S. 1988. Archaeological Survey and Testing for Aiffield Perimeter Fence Project, Bellows Air Force Station, Oahu, Hawaï, report prepared by International Archaeological Research Institute, Inc., for the U.S. Air Force, Honolulu.

Barrera, W. 1987. Saddle Road, Hawaï Island: Archaeological Survey of 138KV Powerline, report prepared for R. M. Towill Corporation, Honolulu (June).

Beckwith, M. 1970. Hawaïan Mythology, University of Hawaii Press, Honolulu (Orig. pub. 1940).

Biosystems Analysis, Inc. 1993. Cultural Resource Management Plan for Native Hawaiian Archaeological Resources, Bellows Air Force Station, draft summary by Janet Eidsness for BioSystems Analysis, Inc. Contract DACA83-91-D-0024 for U.S. Army Corps of Engineers, Pacific Ocean Division, Honolulu (March).

Brennan, J. 1974. The Parke- Ranch of Hawaï: The Saga of a Ranch and a Dynasty, John Day Company, New York. 
Brower, Kenneth. 1992. "The Pig War," pp. 71-100 in A World Between the Waves, Frank Stewart (ed.), Island Press, Washington, D.C.

Buck, M. 1993. "Hunters Seek More Voice in Natural Area Management," Resource (11), State of Hawaii Department of Land and Natural Resources, Honolulu.

Burgett, B. D., and P. H. Rosendahl. 1993. Summary of Archaeological Inventory Surveys: Kapaanui Agricultural Subdivision and Mahukona Property, report prepared for Chalon International of Hawaii, Inc., Hilo (February).

*Burtchard, G. C., and P. Moblo. 1994. Archaeology in the Kilauea East Rift Zone. Part I: LandUse Model and Research Design. Kapoho, Kama'ili and Kilauea Geothermal Subzones, Puna District, Hawai'i Island, report prepared by International Archaeological Research Institute, Inc., for Oak Ridge National Laboratory, Oak Ridge, Tenn. (July).

Clark, J. T., and P. V. Kirch, eds. 1983. Archaeological Investigations of the Mudlane-WaimeaKawaihae Road Corridor, Island of Hawai i: An Interdisciplinary Study of an Environmental Transect, Report 83-1, Bernice Pauahi Bishop Museum Press, Honolulu.

Cordy, R., and M. W. Kaschko. 1980. "Prehistoric Archaeology in the Hawaiian Islands: Land Units Associated with Social Groups," Joumal of Field Archaeology, 7, 403-416.

Crane, J. L., et. al. 1992. Saciology of Hawaï: Facts and Commentary, Harper Collins College Publishers, New York.

Cuddihy, L. W., and C. P. Stone. 1990. Alternation of Native Hawaiian Vegetation: Effects of Humans, Their Activities and Introduction, Cooperative National Park Resources Studies Unit, University of Hawaii, Manoa, Hawaii.

Cuddihy, Linda W. 1989. "Vegetation Zones of the Hawaiian Islands," pp. 27-37 in Conservation Biology in Hawaii C. P. Stone and D. B. Stone (eds.), University of Hawaii Cooperative National Park Resources Studies Unit, Honolulu.

Daws, G. 1968. The Shoals of Time. A History of the Hawaiian Islands, University of Hawaii Press, Honolulu.

DHHL 1993. "Exhibit 1: Areas Impacted by Hawaii Geothermal Project," memorandum prepared by Benjamin Henderson for the State of Hawaii, Honolulu, April 1993. 
DHM Planners, Inc. 1989. "Hawaiian Fishpond Study: Islands of O'ahu, Moloka'i and Hawai'," Bernice Pauahi Bishop Museum, Honolulu, prepared for the Hawaii Department of Land and Natural Resources, Honolulu.

DHM Planners, Inc. 1990. "Hawaiian Fishpond Study: Islands of Hawaii, Maui, Lana'i and Kaua'i," prepared for the Hawaii Coastal Zone Management Program through the state of Hawaii Department of Land and Natural Resources, Honolulu.

DLNR (Department of Land and Natural Resources). 1991a. The Hawaii State Plan: Historic Preservation. State Functional Plan, State of Hawaii, Honolulu.

DLNR (Department of Land and Natural Resources). 1991b. Na Ala Hele: Hawaii Trail \& Access System, Division of Forestry and Wildlife, State of Hawaii, Honolulu, Hawaii, May 1991.

DLNR (Department of Land and Natural Resources). 1993. Na Ala Hele Trails and Access Inventory [in the vicinity of HGP project areas on Maui and the Big Island], provided by Christina Meller, project manager, $\mathrm{Na}$ Ala Hele Trails and Access Program, Division of Forestry and Wildlife, Honolulu, (September).

DLNR (Department of Land and Natural Resources). 1994. DLNR Calendar, Cultural Landscapes 1994, State of Hawaii, Honolulu.

Donham, T. 1992(a). Historic Sites Overview-Kihei/Makena, prepared by State of Hawaii Historic Preservation Division for KiheiMakena Community Plan Citizens Advisory Committee (August).

Donham, T. 1992(b). Summary of State Inventory Sites, Hawaiian Home Lands, Kahikinui, prepared for Ka Ohana O Kahikinui by the State of Hawaii Historic Preservation Division, Honolulu.

Downer, A. S., and A. R. Roberts. 1992. "Traditional Cultural Properties, Cultural Resources Management, and Environmental Planning," U.S. Department of the Interior, National Park Service, CRM 16, 12-14.

Dudley, M. K 1990. Man, Gods, and Nature, Na Kane O Ka Malo Press, Honolulu.

*Erkelens, C. 1995. Phase I Archaeologica! Investigation. Cultural Resources Survey, Hawaii Geothermal Project, Makawao ana Hana Districts, South Shore of Maui, Hawaii, report prepared by International Archaeological Research Institute, Inc., for Oak Ridge National Laboratory, Oak Ridge, Tenn. (February 1995). 
Fake, Thomas. 1994. National Park Service, Honolulu, personal communication with Carl Petrich, Oak Ridge National Laboratory, Oak Ridge, Tenn. (March 16).

Fogelman, V. M. 1960. Guide to the National Environmental Policy Act, Quorum Books, Greenwood Publishing, New York.

Frierson, P. 1991. The Burning Island: A Joumey Through Myth and History in Volcano Country, Hawai'i, Sierra Club Books, San Francisco, Calif., 1991.

Hammatt, H. H., and D. Shideler. 1991. Documents Relating to the Cultural Surveys-Hawaii's Inventory of Hawaïan Home Lands at Kawaihae Excluded from the Main Body of the Report, report prepared by Cultural Surveys of Hawaii for the State of Hawaii Department of Hawaiian Home Lands, Honolulu.

Hammatt, H. H. et. al. 1992. Archaeological Reconnaissance Survey of 56 Acres for the Proposed Olomana Golf Course Expansion Area, report prepared by Cultural Surveys of Hawaii for Wilson Okamoto and Associates, Contract TMK 4-1-13:11 (August).

Hammatt, H. H., and D. Borthwick. 1988. Archaeological Reconnaissance of the Mauka Portion of Phase II Waimanalo Agricultural Park, Waimanalo, O'ahu, report prepared by Cultural Surveys of Hawaii for Akinaka and Associates (January).

Handy, E. S. C., and E. G. Handy. 1972. Native Planters in Old Hawaii: Their Life, Lore, and Environment, Bulletin 233, Bernice P. Bishop Museum, Honolulu (Orig. publ. 1957).

Hasegawa, S. T. 1993, Acting State Land Surveyor, State of Hawaii Department of Accounting and General Services, Honolulu, Hawaii, personal communication to Andrea W. Campbell, Department of Energy, Oak Ridge Field Office, Oak Ridge, Tenn., (August 11).

Hawaii Historic Preservation Division. 1993. State of Hawaii National and State Register of Historic Places, Department of Land and Natural Resources, Honolulu (September).

Howett, C. 1987. "Systems, Signs, Sensibilities: Sources for a New Landscape Aesthetic," Landscape Journal, 6(1), 1-12.

Hunt. T. L 1992. "Archaeological Survey of Proposed Water Transmission Lines and Pump Stations, Saddle Road and Waimea, Island of Hawaiti," Appendix G in Water Resource Development and Across-Island Transmission, Island of Hawaï, revised draft environmental impact statement prepared by Okahara and Associates, Inc., for State of Hawaii Department of Land and Natural Resources (November). 
Kalima, L., and P. H. Rosendahl. 1991. Supplemental Environmental Report: Archaeological Survey of $138 \mathrm{Kv}$ Transmission Line No, 2, Districts of North and South Hilo, Hamakua, and South Kohala, Island of Hawaii, prepared for Ch2M Hill, Honolulu (September).

Kamakau, Samuel M. 1976. "The Works of the People of Old (Na Hana a ka Po'e Kahiko)," B. P. Bishop Museum Special Publication 61, Bishop Museum Press, Honolulu.

Kamins, R. M. 1980. Do Native Hawaïans Have a Special Claim to Geothermal Resources in Hawaï? A Legal Analysis," typescript manuscript prepared for the State of Hawaii Department of Planning and Economic Development, Honolulu (November).

Kanahele, George Hu'eu Sanford. 1986. Ku Kanaka-Stand Tall: A Search for Hawaïan Values, University of Hawaii Press and Waiaha Foundation, Honolulu.

Kaplan, R., and S. Kaplan. 1989. The Experience of Nature: A Psychological Perspective, Cambridge University Press, Cambridge, Mass.

Kaplan, S., and J. F. Talbott. 1983. "Psychological Benefits of a Wilderness Experience," pp. 163-203 in Human Behavior and Environment: Volume 6. Behavior and the Natural Environment, eds. I. Altman and J. F. Wohlwill, Plenum Press, New York.

Kawikuamookekuaokalani-Henry, Mahealani. 1992 "The Hawaiian Side," letter submitted to the U.S. Department of Energy during scoping proceedings for the proposed Hawaii Geothermal Project, Exhibit 1991461A.

Kennedy, J. 1987. "Hawaiian Archaeology: The Pursuit of Antiquity in a Very Small Place," Archaeology, 40(5), 58-63.

King, T. F. 1990. "Section 106 and AIRFA: Pragmatic Relationships," pp. 207-236 in eds.

A. L. Kiesert and A. S. Downer, Preservation on the Reservation, Navajo Nation Papers in Anthropology, No. 26.

Kirch, P. V. 1985. Feathered Gods and Fishhooks: An Introduction to Hawaïan Archaeology and Prehistory, University of Hawaii Press, Honolulu.

Knox, J. M. 1990. "Selected Sociocultural Implications of an Ocean Minerals Processing Plant for Ewa, Kohala, or Puna," Appendix D in Proposed Marine Mineral Lease Sale: Exclusive Economic Zone Adjacent to Hawaii and Johnston Island, Final Environmental Impact Statement prepared for U.S. Department of the Interior and State of Hawaii Department of Business and Economic Development, Honlulu (August) 
Lachman, R., and W. J. Bonk 1960. "Behavior and Beliefs during the Recent Volcanic Eruption at Kapoho, Hawaii," Science 131(3407), 1095-1096.

Lam, M. C. 1989. "The Kuleana Act Revisited: The Survival of Traditional Hawaiian Commoner Rights in Land," Washington Law Review 64(227), 233-288.

Langlas, C. 1990. The People of Kalapana 1823-1950: A Report of the Kalapana Oral History Project. Hilo (second printing).

Linnekin, J. S. 1983. "Defining Tradition: Variations on the Hawaiian Identity," American Ethnologist 10, 241-252.

Linnekin, J. S. 1985. Children of the Land: Exchange and Status in a Hawaiian Community, Rutgers University Press, New Brunswick, N.J.

Lucas, P. N. 1993, Attorney for the Native Hawaiian Legal Corporation, personal communication to Lillian D. Trettin, Oak Ridge National Laboratory, Oak Ridge, Tenn. (March 23).

Maciolek, J. A 1986. "Environmental Features and Biota of Anchialine Pools on Cape Kinau, Maui, Hawaii," Stygologia 2(1-2), 119-129.

MacKenzie, M. K, ed. 1991. Native Hawaïan Rights Handbook, Native Hawaiian Legal Corporation, Honolulu.

Magida, L. 1992. "In Search of Real Hula," New York Times, Travel Section, 12 (December 27).

Mander, J. 1991. In the Absence of the Sacred: The Failure of Technology and the Survival of the Indian Nation, Sierra Club Books, San Francisco, Calif.

"Matsuoka, J. K, D. P. McGregor, L Minerbi, M. Kelly, and N. Barney-Campbell. 1995. Native Hawaiian Ethnographic Study for the Hawaiti Geothermal Project Proposed for Puna and Southeast Maui, report prepared by Cultural Advocacy Network for Developing Options (CANDO) for Oak Ridge National Laboratory, Oak Ridge, Tenn. (September).

McClelland, L. F. 1990. Guidelines for Evaluating and Documenting Rural Historic Landscapes. National Register Bulletin 30, prepared for the U.S. Department of the Interior, National Park Service, Washington, D.C.

McEldowney, H. 1979. "Archaeological and Historical Literature Search and Research Design. Lava Control Study-Hilo, Hawaii," prepared for U.S. Army Engineer Division, Pacific 
Ocean District by Department of Anthropology, Bernice P. Bishop Museum, Honolulu (May).

McEldowney, H. 1993, State Historic Preservation Division, personal communication with Lillian D. Trettin, Oak Ridge National Laboratory, Oak Ridge, Tenn. (September 8).

McEldowney, H. 1994. State Historic Preservation Division, personal communication with Lillian D. Trettin, Oak Ridge National Laboratory, Oak Ridge, Tenn. (December 22).

McEldowney, H., and F. D. Stone. 1991. "Survey of Lava Tubes in the Former Puna Forest Reserve and on Adjacent State of Hawaii Lands," prepared for the State Historic Preservation Division, Department of Land and Natural Resources, Honolulu.

McGregor, D. P. 1990. "'Aina Ho'opulapula: Hawaiian Homesteading," The Hawaiian Journal of History 24, 1-38.

McManamon, F. P. 1992. "Managing Repatriation: Implementing the Native American Graves Protection and Repatriation Act," CRM 15(5), 9-12.

Meller, C. B. 1994. Na Ala Hele Trails and Access Program Manager, personal correspondence with Lillian D. Trettin, Oak Ridge National Laboratory, Oak Ridge, Tenn. (March 18).

Melnick, R. Z 1984. Cultural Landscapes: Rural Historic Districts in the National Park System, National Park Service, Washington, D.C.

Minerbi, L., D. McGregor, and J. Matsuoka. 1993. Hawai'i Environmental Risk Ranking: Native Hawaiian Assessment, report prepared by Cultural Action Network Developing Options (CANDO) for State of Hawaii Department of Health, Honolulu.

National Park Service. 1987. Catalog of National Historic Landmarks, Washington, D.C.

National Park Service. 1992. National Register Information System List for the state of Hawaii, Washington, D.C. (April 27).

National Park Service. 1993. Master Agreement for a Cooperative Strategy for Hawaii Volcanoes National Park, draft Agreement, U.S. Department of the Interior, the U.S. Fish and Wildlife Service, the State of Hawaii, and Bishop Estate (August). 
Native Hawaiian Study Commission. 1983. Claims of Conscience: A Dissenting Study of the Culture, Needs and Concerns of Native Hawaiians, Vol. 2 submitted to the U.S. Senate and the U.S. House of Representatives (June 23).

Nelson, V. 1992. "Into the Archipelago," pp. 56-70 in A World Between the Waves, ed. Frank Stewart, Island Press, Washington, D.C.

Nimmo, H. A. 1986. "Pele, Ancient Goddess of Contemporary Hawaii," Pacific Studies 9(2) (March).

Nimmo, H. A. 1992. The Pele Literature: An Annotated Bibliography of the English-Language Literature on Pele, Volcano Goddess of Hawai'i, Bishop Museum Bulletin in Anthropology 4, Bishop Museum Press, Honolulu.

O'Connor, M. I. 1989. "Environmental Impact Review and the Construction of Contemporary Chumash Ethnicity," pp. 9-17 in Negotiating Ethnicity: The Impact of Anthropological Theory and Practice, ed. Susan E. Keefe, NAPA Bulletin 8, American Anthropological Association.

Olsen, M. E., P. Canan, and M. Hennessy. 1985. "A Value-based Community Assessment Process: Integrating Quality of Life and Social Impact Studies," Sociological Methods and Research 13(3), 325-361.

Paper, J. 1990. "Through the Earth Darkly: The Female Spirit in Native American Religions," in Religion in Native North America, ed. Christopher Vecsey, University of Idaho Press, Moscow, Id.

Parker, L. S. 1989. Native American Estate: The Struggle over Indian and Hawaïian Lands, University of Hawaii Press, Honolulu.

Parker, P. L, and T. F. King. 1990. National Register Bulletin 38: Guidelines for Evaluating and Documenting Traditional Cultural Properties, prepared for the U.S. Department of the Interior, National Park Service, Washington, D.C.

Pele Defense Fund. 1990. "Petition for Declaration under Section 26 of the Hawai'i State Water Code for all the waters, surface, and of ground, Puna District, Hawai'i Island," State of Hawaii, Commission on Water Resources Management, Honolulu. 
Pele Defense Fund. 1992. "Intervenor Aluli/Dedman's Closing Statement," November 15, 1985, included in the Pele Defense Fund Agenda for Scoping Meeting, Hawaii Geothermal Project (March 7).

Pele Defense Fund. 1992. Pele Defense Fund v. Paty, 837 P. 2 d 1247.

Pele Defense Fund. 1992. "Statement of Pele Perspectives and Concerns against Geothermal Impact," included in the Pele Defense Fund Agenda for Scoping Meeting, Hawaii Geothermal Project (March 7).

Petrich, C. H. 1993. "Science and the Inherently Subjective: The Evolution of Aesthetic Assessment Since NEPA," pp. 249-272 in Environmental Analysis: The NEPA Experience, eds. S. G. Hildebrand and J. B. Cannon, CRC Press, Inc., Boca Raton, Fla.

Petrich, C. H., S. F. Railsback, and M. M. Swihart. 1989. "Instream Flows for Recreational and Aesthetic Resources," pp. 100-107 in Legal, Institutional, Financial, and Environmental Aspects of Water Issues, American Society of Civil Engineers, New York.

Piianaia, A. 1986. "The Pele Syndrome: Some Factors Worth Knowing," Applicant's Exhibit 19, prepared by the Director, Hawaiian Studies Program, Honolulu (February 13).

Porterfield, A. 1990. "American Indian Spirituality as a Countercultural Movement," in Religion in Native North America, ed. Christopher Vecsey, University of Idaho Press, Moscow, Id.

Puna Aloha Aina. 1992. "Meeting Notes-Hawaiian Families of Puna, August 5, 1992," Kalapana, Puna District, Hawaii.

Puna Hui Ohana. 1982. "Assessment of Geothermal Development Impact on Aboriginal Hawaiians," prepared for the U.S. Department of Energy, San Francisco.

Reddick, P. B. 1984. "Waimea Design Plan," prepared for County of Hawaii, Department of Housing and Urban Development (May).

Reinhold, R. 1992. "A Century After Queen's Overthrow, Talk of Sovereignty Shakes Hawaii," New York Times, Section A, 14 (November 8).

Rosendahl, P. H., and L. A Carter. 1988. "Excavations at John Young's Homestead. Kawaihae, Hawaii: Archeology at Pu'ukohola Heiau National Historic Site," prepared for the U.S. Department of the Interior, National Park Service. 
Rowe, J. 1991. Comments made at the Hawaii Geothermal Project EIS Information Exchange/Cooperating Agency Meeting, November 15, 1991.

Schnaiberg, A 1986. "Reflections on Resistance to Rural Industrialization: Newcomers' Culture of Environmentalism," pp. 229-260 in Differential Social Impacts of Rural Resource Development, ed. Pamela D. Elkind-Savatsky, Social Impact Assessment Series No. 13, Westview Press, Boulder, Colo.

State of Hawaii. 1993. Act 156, A Bill for an Act Relating to Cultural Landscapes, Session Laws of Hawaii, Regular Session 1993, Honolulu.

Sharples, F. E., and Salk, M. S. 1988. The American Indian Religious Freedom Act: Guidance for Compliance by Federal Agencies, ORNL/6166/R1, Oak Ridge National Laboratory, Oak Ridge, Tenn.

Stoffle, R. W., M. J. Evans, and J. E. Olmsted. 1992. "Calculating the Cultural Significance of American Indian Plants: Paiute and Shoshone Ethnobotany at Yucca Mountain, Nevada," American Anthropologist 92, 416-432.

*Sweeney, M., and G. Burtchard. 1995. "Archaeology in the Kilauea East Rift Zone. Part II: A Preliminary Sample Survey. Kapoho, Kama'ili and Kilauea Geothermal Subzones, Punà District, Hawai'i Island," prepared by International Archaeological Research Institute, Inc., for Oak Ridge National Laboratory, Oak Ridge, Tenn., May.

Swihart, M. M., and C. H. Petrich. 1988. "Assessing the Aesthetic Impacts of Small Hydropower Development," Environmental Professional 10(3), 198-210.

Tomonari-Tuggle, M. J. 1981. "North Kohala, Perception of a Changing Community: A Cultural Resource Management Study," prepared for the state of Hawaii Department of Land and Natural Resources, Division of State Parks, Honolulu, Hawaii.

Townscape, Inc. 1992. "Northwest Hawaii Open Space and Community Development Plan," public draft report, prepared for County of Hawaii, Honolulu, November.

Trask, H. K. 1993. "What Do You Mean 'We,' White Man?" pp. 161-178 in From a Native Daughter: Colonialism and Sovereignty in Hawai'i, Common Courage Press, Monroe, Maine.

Tuggle, D. H., and P. B. Griffin, eds. 1973. "Lapakahi, Hawai'i Archaeological Studies," Social Science Research University of Hawaii, Honolulu, Hawaii. 
Ulrich, David. 1993. "Hawai'i: Landscape of Transformation," Parabola: Place and Space, XVIII(2), 50-53 (summer).

University of Hawaii, Department of Geography. 1983. Atlas of Hawaii, 2nd ed., University of Hawaii Press, Honolulu, Hawaii.

Vecsey, C., ed. 1991. Handbook of American Indian Religious Freedom, Crossroads Publishing, New York.

Welch, D. J. 1991. "Archacological Survey and Testing for the Saddle Road Improvement Project, Pohakuloa Area, Hawaii, Hawaii," prepared by International Archaeological Research Institute, Inc., for the U.S. Department of the Interior, National Park Service, August.

Wilson, E. O. 1984. Biophilia, Harvard University Press, Cambridge, Massachusetts, 1984.

Wyban, C. A. 1992. Tide and Current: Fishponds of Hawai'i, University of Hawaii Press, Honolulu, Hawaii.

\footnotetext{
* All marked archaeological reports and the Native Hawaïan Ethnographic Study (Matsuoka et al. 1995) are available at the Hawaii State Historic Preservation Division, Department of Land and Natural Resources, Honolulu.
} 


\section{APPENDIX}

State and federal legislation relevant to the protection of cultural resources and practices are addressed in this appendix. Many of the acts stress the importance of initiating adequate consultation with Native Americans early in the project review process:

\section{Major Federal Legislation}

American Indian Religious Freedom Act (AIRFA) of 1978 [42 USC 1996, Pub. L. No. 95-341, 1978]. The intent of this law is to ensure that actions undertaken or licensed by federal agencies do not interfere with the inherent right of individual Native Americans (including American Indians, Eskimos, Aleuts, and Native Hawaiians) to express and practice their traditional religions. These rights include access to religious sites, use and possession of sacred objects, and the freedom to worship through traditional ceremonials. When a federal agency finds, upon consultation, that its proposed action would deny the free exercise of religion and yet determines that there is a compelling need for the action, the decision to proceed may be made. However, appropriate mitigation measures to reduce interference with traditional religious practice to the lowest possible level must be included.

Archaeological Resources Protection Act (ARPA) of 1979, as amended [16 USC 470aa-470mm; Pub. L. No. 96-95 (1979), and amendments thereto]. Regulations, 43 CFR 7. This law protects archaeological resources on public lands and American Indian lands. Federal agencies must notify American Indian tribes prior to taking any action that could affect cultural and sacred sites located on federal land. One provision of the law substantially increases the severity of civil and criminal penalties imposed on unqualified and unpermitted looters. The act does not specifically address Native Hawaiians; however, by implementing ARPA, federal agencies have promoted guidelines and policies that encourage early consultation with concerned native people.

Archaeological and Historic Preservation Act (AHPA) of 1974 [16 USC 469-469c; Pub. L. 86-532 (1960), and amendments thereto]. This law provides for the preservation of historical and archaeological data that might otherwise be lost as the result of the construction of a dam, or similar alteration of the terrain caused by a federal or federally licensed construction project. For instance, provisions of the act apply if a project requires placement of dredged materials along a coast.

National Environmental Policy Act (NEPA) of 1969, as amended [42 USC 4371 et. seq., Pub. L. 91-190 (1970), and amendments thereto]. Regulations of the Council on Environmental Quality, 40 CFR. 1500-1517. NEPA charges federal agencies with identifying and implementing

practicable measures to help the Nation "preserve important historic, cultural, and natural aspects 
of our national heritage, and maintain, wherever possible, an environment which supports diversity and variety of individual choice."

National Historic Preservation Act (NHPA) of 1966, as amended in 1992 [16 USC 470; 80 Stat. 915; Pub. L. No. 89-665 (1966), and amendments thereto]. Regulations: Protection of Historic Properties (Advisory Council on Historic Preservation) 36 CFR Part 800, as amended. Additions in the 1992 amendments of particular significance for traditional native cultures include: Section 304 (a)-(b) on withholding sensitive information from public disclosure and Section 101 (d)(6) (A)-(C), which specifies attention to traditional cultural properties of religious significance and requires the state of Hawaii to consult with Native Hawaiians during Section 106 review of projects.

Native American Graves Protection and Repatriation Act (NAGPRA) of 1990 [25 USC 3001-3013; Pub. L. 101-601 (1990)]. Regulations (Proposed Rule, F.R. May 28, 1993), 43 CFR 10. The act provides guidance on how Native American remains and burial artifacts should be treated; provisions deal with federally funded museum collections and with archaeological investigations on federally managed land. NAGPRA encourages in situ preservation of archaeological sites that include burials and requires that federal agencies consult with affiliated, or potentially affiliated, Native Americans concerning the treatment and disposition of cultural remains. Native Hawaiian organizations and Native Hawaiian Home Lands are specifically cited.

Religious Freedom Restoration Act (RFRA) of 1993 [42 USC 2000 bb; Pub. L. 103-141 (1993)]. If a federal agency argues for the compelling need to proceed with a federally funded project despite the certainty that the project would deny the free exercise of religion, this act requires the agency to demonstrate that compelling need.

\section{Recent and Additional Federal Legislation}

Federal Cave Resources Protection Act of 1988 [16 USC 4302-4309; Pub. L. 100-691].

Executive Order 12898, Federal Actions to Address Environmental Justice in Minority Populations and Low-income Populations. F.R. February 11, 1994.

Public Law 103-150. Resolution on the 100th Anniversary of the Overthrow of the Hawaiian Kingdom. November 23, 1993. 
State Legislation

\section{Customary Native Hawaiian rights:}

Hawaii Revised Statutes, Section 7-1. This section ensures that Native Hawaiians retain gathering rights to specific products and resources for private use, rights of access to tenant property or common rights-of-way, and water rights.

Hawaii Revised Statutes, Section 1-1. This "customary usage" provision protects rights to collect additional products and resources not specified in 7-1 and to practice other traditional customs.

Hawaii Revised Statutes, Section 174-101 (1989 supplement). This section of the State Water Code asserts that customary Native Hawaiian water rights cannot be abridged.

Hawaii State Constitution (as amended in 1978), Article XII, Section 7. "The State reaffirms and shall protect all rights, customarily and traditionally exercised for subsistence, cultural, and religious purposes and possessed by ahupua'a tenants who are descendants of native Hawaiian Islanders prior to 1778 , subject to the right of the State to regulate such rights."

Hawaiian Homes Commission Act, Sections 204-207. These sections govern whether the State can lease or swap Hawaiian Home Lands. In the event of such a transaction, benefits are intended to accrue to Native Hawaiians.

Protection of culturally significant and historic sites and trails:

Hawaii Revised Statutes, Chapter 6E-1 (1985): The Hawaiian Historic Preservation Law adopts criteria established in the NHPA with additional criteria on burial sites and other traditional sites of ethnic importance. The Law mandates review by the State Historic Preservation Division of all state and county undertakings. As with the federal law, "undertaking" includes a range of actions including permits, use of state-owned lands, and expenditures of state funds.

Act 265 (1988). This amendment to the Hawaiian Historic Preservation Law establishes provisions regarding discovery of prehistoric and historic burial sites and makes the law one of the most protective state historic preservation laws in the nation.

Act 3296 (1990). This act amends existing law to protect unmarked prehistoric and historic Hawaiian burial sites. 
Act 306 (1990). The Hawaiian Burial Law establishes island burial councils. These must be consulted prior to intentional excavation or in the case of inadvertent discovery of burial remains and artifacts.

Act 156 (1993). The "Act Relating to Cultural Landscapes" defines five landscape types (ethnographic landscapes, historic scenes, historic sites, historic vernacular landscapes, and historic designed landscapes) and establishes a task force to develop criteria for designating these resources in the state of Hawaii.

Hawaii Revised Statutes, Chapter 264, Section 1 (as amended in 1988). Formerly known as the Highways Act of 1892, this section specifically defines public trails, including those of cultural significance.

Hawaii Revised Statutes, Chapter 198D [Act 236 (1974)]. This act establishes the Na Ala Hele Trails and Access System under the state of Hawaii Department of Land and Natural Resources.

\section{Guidelines}

Many of the guidelines that have been developed for federal agencies encourage early consultation with concerned Native Americans and stress the importance of maintaining confidentiality when requesting access to sensitive information. Where formerly regulations addressed American Indian Tribes and "other" Native Americans, the recent trend in congressional and legislative activity is to support more explicit treatment of Native Hawaiians' issues. Guidance for consulting with Native Americans, and particularly with Native Hawaiians, includes the following documents:

Advisory Council on Historic Preservation. 1990. Section 106 Participation by Indian Tribes and Other Native Americans. Washington, D.C.

King, Thomas F. 1990. "Section 106 and AIRFA: Pragmatic Relationships." Preservation on the Reservation, eds. A. L. Kiesert and A.S. Downer, Navajo Nation Papers in Anthropology, No. 26, 207-236.

MacKenzie, Melody Kapilialoha, ed. 1991. Native Hawaïan Rights Handbook Native Hawaiian Legal Corporation, Honolulu.

McManamon, Francis P. 1992. "Managing Repatriation: Implementing the Native American Graves Protection and Repatriation Act," CRM, 15 (5) 9-12. 
Parker, Patricia L. and Thomas F. King. 1990. Guidelines for Evaluating and Documenting Traditional Cultural Properties, National Register Bulletin No. 38, prepared for the U.S. Department of the Interior, National Park Service.

Sharples, Frances E. and Martha S. Salk. 1988. The American Indian Religious Freedom Act: Guidance for Compliance by Federal Agencies, ORNL-6166/R1, Oak Ridge National Laboratory, Oak Ridge, Tenn.

\section{Consulting with Native Hawaiians}

Part 10.2 (a) (11) (i-iii) of NAGPRA and Section 301 (18) (A)-(C) of NHPA indicate that, in the absence of tribal government, consultation should occur with Native Hawaiian organizations. "Native Hawaiian organization" means any organization which (A) serves and represents the interests of Native Hawaiians; (B) has as a primary and stated purpose the provision of services to Native Hawaiians; and (C) has demonstrated expertise in aspects of historic preservation that are culturally significant to Native Hawaiians. The term includes, but is not limited to, the Office of Hawaiian Affairs of the State of Hawaii and Hui Malama I Na Kapuna O Hawai'i Nei, an organization incorporated under the laws of the State of Hawaii." 

ORNL/TM-12859

\section{INTERNAL DISTRIBUTION}

$\begin{aligned} \text { 1. } & \text { G. E. Courville } \\ \text { 2. } & \text { F. M. Glenn } \\ \text { 3. } & \text { C. H. Petrich } \\ \text { 4-13. } & \text { R. M. Reed } \\ \text { 14. } & \text { D. E. Reichle } \\ \text { 15. } & \text { J. W. Saulsbury } \\ 16 . & \text { A. C. Schaffhauser }\end{aligned}$

\author{
17. R. B. Shelton \\ 18-19. Laboratory Records \\ 20. Laboratory Records-RC \\ 21. Document Reference Section \\ 22. Central Research Library \\ 23. ORNL Patent Section
}

\section{EXTERNAL DISTRIBUTION}

24. Office of the Assistant Manager for Energy Research and Development, Department of Energy, Oak Ridge Operations, P. O. Box 2001, Oak Ridge, TN 37831

25. Andrea Campbell, Department of Energy, Oak Ridge Operations, Bldg. 1714J, SE-311, Oak Ridge, TN 37831-8739

26. Ross Cordy, State Historic Preservation Division, 33 S. King Street, 6th Floor, Honolulu, HI 96813

27. Theresa Donham, State Historic Preservation Division-Maui, 1325 Lower Main St., Suite 108, Wailuku, HI 96793

28. Virginia H. Goldstein, Director, Hawaii County Planning Commission, 25 Aupuni Street, Room 109, Hilo, HI 96721

29. Hugo Huntzinger, Superintendent, Hawaii Volcanoes National Park, P. O. Box 52, Hawaii Volcanoes National Park, HI 96718-0052

30. Maurice H. Kaya, Energy Program Administrator, Department of Business, Economic Development \& Tourism, 335 Merchant Street, Suite 108, Honolulu, HI 96813

31-35. Allan J. Jelacic, Office of Renewable Energy Conversion (EE-12), U.S. Department of Energy, Forrestal Building, 1000 Independence Ave. SW, Washington, DC 20585

36. Kalvin K Kobayashi, Energy Program Administrator, Department of Planning, Energy Extension Service Division, County of Maui, 250 S. High Street, Wailuku, HI 96793

37. Mike Lee, Chief, Operations Division, Honolulu Engineer District, Building 230, Fort Shafter, HI 86858-5440

38. Jon Matsuoka, 2367 Kaululaau St., Honolulu, HI 96813

39. Holly McEldowney, State Historic Preservation Division, 33 S. King Street, 6th Floor, Honolulu, HI 96813

40. Davianna McGregor, 1942 Naio St., Honolulu, HI 96817

41. Luciano Minerbi, 2444 Hihiwai St., No. 2005, Honolulu, HI 96826

42. John Naughton, Pacific Area Office, National Marine Service, National Oceanic and Atmospheric Administration, 2570 Dole Street, Honolulu, HI $96822-2396$

43. Manuel Nathenson, U.S. Geological Survey, Geologic Division, Branch of Volcanic and Geothermal Processes, 345 Middlefield Road, M/S 910, Menlo Park, CA 94025

44. Robert Smith, Director, Pacific Island Office, U.S. Fish and Wildlife Service, Prince Kuhio Building, Room 6307, 300 Ala Moana Boulevard, Honolulu, HI 96850

45. Judith C. Stroud, ER-10, Department of Energy, Oak Ridge Operations Office, P. O. Box 2001, Oak Ridge, TN 37831-6600 
46. Lillian D. Trettin, $\mathbf{7 1 2}$ Wakendaw Blvd., Mount Pleasant, South Carolina 29464

47-48. Office of Scientific and Technical Information, P. O. Box 62, Oak Ridge, TN 37831 